\title{
LA-7179-MS
}

\section{Uranium Hydrogeochemical and Stream Sediment Reconnaissance of the Rawlins NTMS Quadrangle, Wyoming}

\author{
Thomas A. Weaver \\ Wayne A. Morris \\ Pam K. Trexler
}

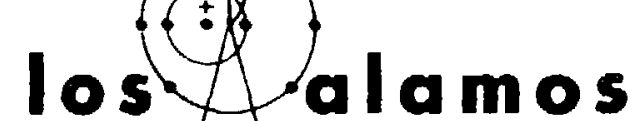

scientific laboratory of the University of California LOS ALAMOS NEW MEXICO B7545<smiles>[3H][CH][13CH2][13CH3]</smiles>

An Allirmative Action/Equal Opportunity fmployer 
LIST OF TABLES

ABSTRACT

Thas repont was prepared as an account of work sponsored by the Unised Sutes Goremment. Neviher the Uniled States nor the United States Depunment of Energy, not any of their employess, not any of theit contractors, subeontreturs, or thels employees, makes any waragry. express or implied, or asumes any lega

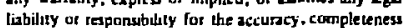

or usefulnews of any information, appasatus, product or

prucess disclosed, ar represents that its use whuld not

infrugge pnotely awned rights.

Geographic Setting climate

MOTICE YN ONLT

Regional Setting

Structure

Stratigraphy

Hydrology

Urzaium Oecurrences

\section{PORTIONS OF THIS REPORT ARE ILLEGIBLE It has been rejrof aned from the best availablo copy to permit the broadest possible avail ability.}

IV. ANALYTICAL AND STATISTICAL DATA FOR URANIUM

CONCENTRATIONS IN WATER AND SEDIMENT SAMPLES

Uranium Concentrations in Water Samples

Uranium Concentrations in Sediment Samples

V. SUMMARY AND CONCLUSIONS

ACKNOWLEDGMENTS

REFERENCES

APPENDIX A Summary of Standard LASL HSSR Field and Analytical Procedures

APPENDIX B Listings of Field Data and Uranium Concentrations for Water Samples

APPENDIX C Listings of Field Data and Uranium

Concentrations for Sediment Samples

APPENDIX D Code to Data Listings

D-I Explanation of Codes Used 
Fig. No.

1. Index and drainage map for the Rawlins quadrangle, Wyoming.

2. Major structural features in the visinity of the Rawlins quadrangle, Wyoming.

3. Histogram of the uranium concentrations ia waters from the Raw?ins quadrangle, Wyoming.

4. Histogram of the uranium concentrations in sediments from the Rawlins quadrangle, Wyoning.

Plate No.

I. Geologia map of the Rawlins NTMS quadrangla, Wyoming.

pocket

II. Sample location overlay for the Rawlins NTS quadrangle, Wyoming.

pocket

[II. Uranium concentrations (ppb) in waters - overlay to the Rawlins NTMS quartrangle, Wyoming.

pocket

IV. Uranium concentrations ( $\mathrm{ppm}$ ) in sediments - overlay to the Rawlins NTMS quadrangle, Wyoming.

pocket

\section{i,IST OF TABLES}

[. Reported Uranium Cccurrences in the Rawlins Quadrangle

IT. Summary of Uranium Data for Water Samples Collected in the Rawlins Quadrangle

III. Relevant Data for Water Samples with Uranium Concentrations Above an Arbitrary Anomaly Threshold of $50 \mathrm{ppb}$

IV. Summary of Uranium Data for Sediment Samples Collected in the Rawlins Quadrangle

V. Relevant Data for Sediment Samples with Uranium Concentrations above an Arbitrary Anomaly Threshold of $9 \mathrm{ppm}$ 
URANIUM HYDROGEOCHEMICAL, AND STREAM SEDIYIENT RECONNAISSANCE

OF THE RAWLINS NTMS QUADRANGLE, WYOYING

by

Thomas A. Weaver, Wayne A. Morris, and Dam K. Trexler

\section{ABSTRACT}

During the spring and winter of 1975 and January and June of 1977,570 natural water and 1381 waterborne ;ediment samples were collected from 1369 locations in the Rawlins, Wyoming, NTMS quadrangle. The samples obtained from tinis $13700-\mathrm{Kn}^{2}$ area were analyzed $z t$ the Los Alamos Soientific Laboratory for total uranium. The uranium concentrations i.a waters ranged from less than the detectable linit of 0.2 parts per billion (ppb) to $448 \mathrm{ppb}$, with a mean value of $6 \mathrm{ppb}$. The concentraijions in sediments ranged from l.? parts per jillion (ppm) to $50.4 \mathrm{ppm}$, with a mean value of $4.2 \mathrm{ppm}$. Based on sinple statistical analyses of these data, arbitrary anomaly threshoids were set at $50 \mathrm{ppb}$ for water samples and $9 \mathrm{ppm}$ for sediment. samples, Jleven water and 44 sediment samples were considered anomalous; $l$ anomalous water and 25 anomalous sediments could be assosiated with four of the iive major uranium occurrenees in the quadrangle. Only the Ketchum Buttes area did not show up in the data. Twelve minor reported occurrences could not be identified by the data.

Eleven anomalous samples (3 waters and 3 sediments) and 13 near-anomalous samples ( 10 waters and 3 sediments) outline a broad area in the northeast corner of the quadrangle (corresponding to the drainage area of the Medicine Bow River) where two airborne radiometric anomalies were discovered in an earlier study. This area, and perhaps others, may warrant furtier, more detailed geological, geophysical, and geochemical investigations. 
This report describes work done in the Raslins, Wyoming, National Topographic Map Series (VTMS) quadrangle (US Geological Survey, 1958) by the Los Alamos Scientific Laboratory (LASL) as part of the nationwide Hydrogeochemical and Stream Sediment Reconnaissance (HSSR). The HSSR, a part of the National Uranium Resource Svaluation (NURE) program sponsored by the US Department of Energy (DOE), is designed to identify areas having higher than normal eoncentrations of uranium in ground waters, surface waters, and water-transported sediments. The HSSR data will ultimataly be combined with data from other NURE prograns (e.g., from airborne radiometric surveys and geological investigations) to prepare an improved assessment of the potential uranium resources in the Us and to indicate areas favorable for uranium exploration by the private sector. The LASL is responsiole for conducting the HSSR in the Rocky Mountain states of New Mexi o, Colorads, Wyoming, and Montana, and in Alaska.

A total of 570 water and 1281 sediment samples were collected from 1369 locations in the Rawlins quadrangle. The majority of the area was sampled from late lay to mid-July 1976 by a private contractor. The remaining area, together with several locations selected to fill in gaps in the areal zoverage of the first contrast, was sampled from mid-December 1976 to late January 1977 and during June 1977 by another private contractor. The sample locations were specified by the LASL and the samples were collected using maps, field equipment, and materials supplied by the LASL. Throughout the study, standardized iield and analyticai techniques developed by the LASL (Sharp, 1977), summarized in Appendix A, were utilized so that sample data in this report may be compared to those in other LASL HSSR reports on surrounding areas.

The plates (all at 1:250 000 scale) in the rear pocket are: a geologic map of the study area on Plate $\mathrm{L}$, a sample location overlay on Plate LT, $a$ 'dranium concentration overlay for waters on Plate III, and a uranium concentration sverlay for sedimentis on Plate IV.

\section{DESCRIPTION OF STUDY AREA}

\section{Geographic Setting}

The Rawlins NTMS quadrangle covers approximately $18700 \mathrm{~km}^{2}$ in southcentral Wyoming (Fig. 1). The area is jounded by latitudes $41^{\circ}$ and $42^{\circ}$ north and Ingitudes $106^{\circ}$ and $108^{\circ}$ west and includes much of Carbon and parts of Sweetwater and Albany Counties. Interstate 80 traverses the area from east to west; Wyoming State Highway 789 is the major norti-south arterial.

The study area includes portions of two physiographic provinces, the Wyoming basin and the Southern Rocky Mountains (Fig, 2). The Nyoming basin covers most of the northern, north-central, and western parts of the area. The Sierra Madre and the Medicine Bow Mountajns, in the south-central and southeastern portions of the area, respectivaly, are northern extensions of the Scuthern Rocky Mountains. The Continental Divide traverses the quadrangle Prom along the Sierra Madre to the northwestern corner; near Rawlins, it separates i.to two branches, enclosing the Great Divide Basin.

Elevation 3 in the study area range from $1860 \mathrm{~m}$ above sea level (ASL) near Baggs, Wyoming, to 3659 m ASL at Medicine Bow Peak. There are several peaks in both the Medisine Bow Mountains and the Sierra Madre Mountains which exceed $3000 \mathrm{~m}$ ASL. Typical elevations in the Wyoming basin range from 1900 to $2300 \mathrm{~m} \mathrm{ASI}$. 


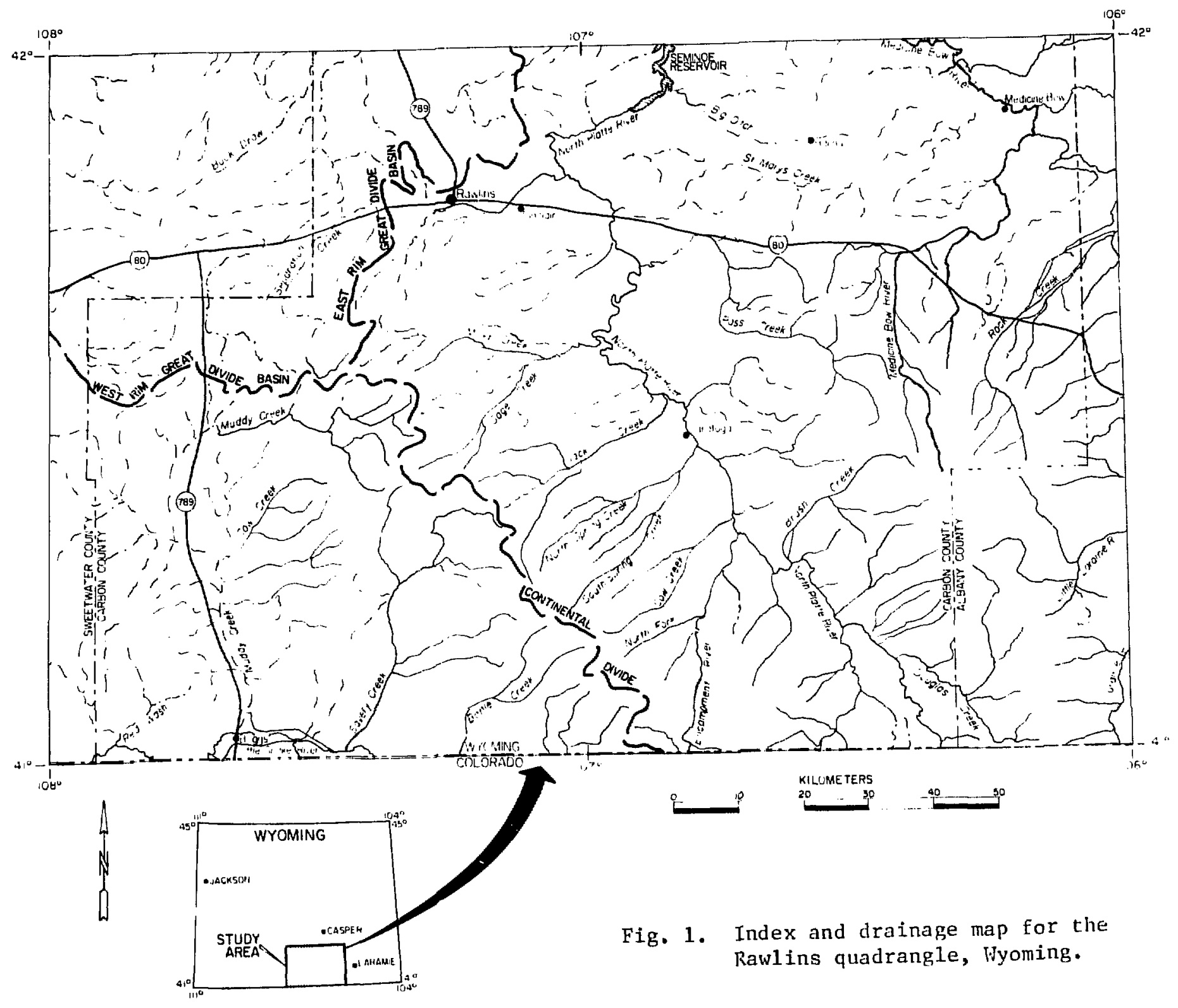




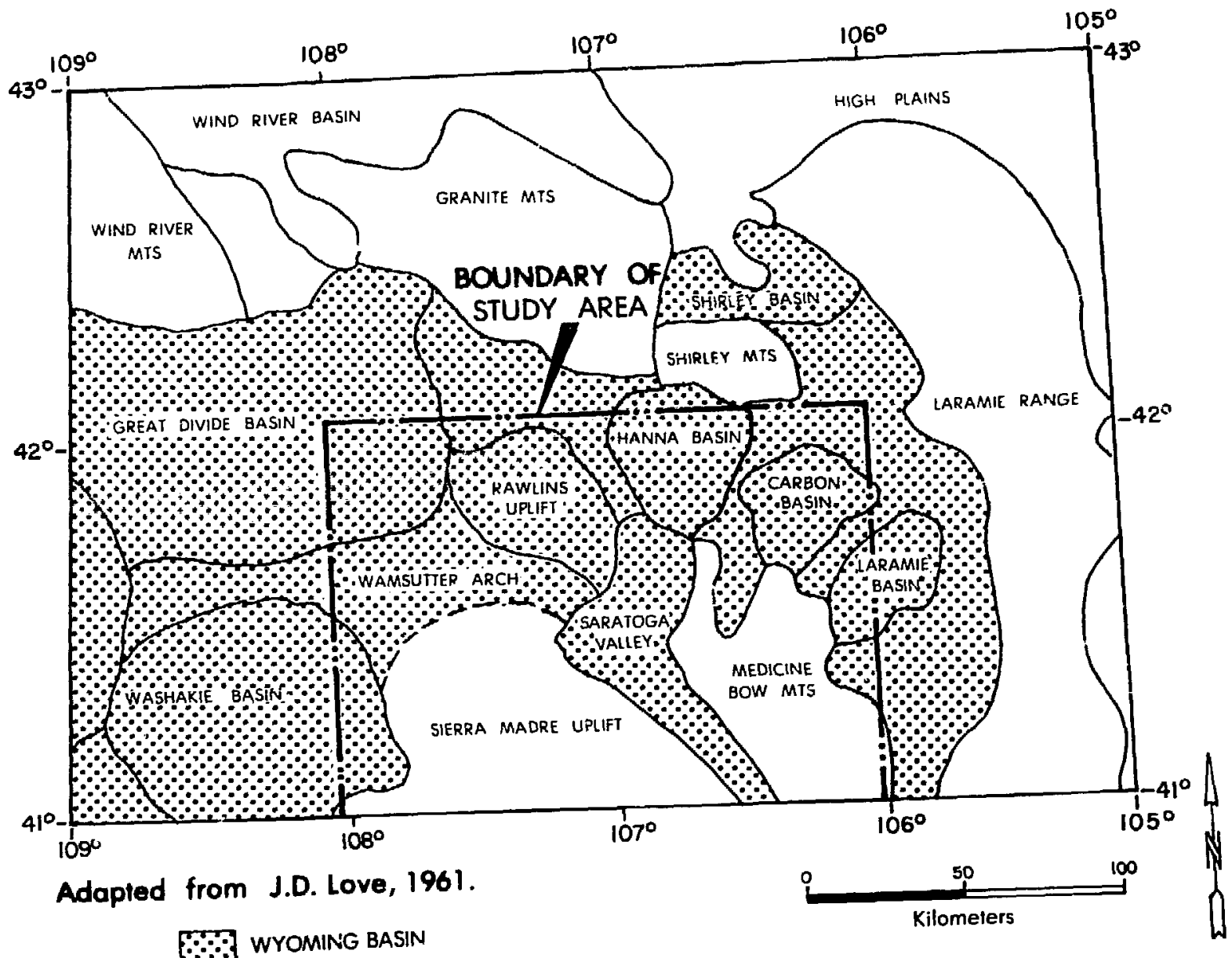

Fig. 2. Major structural features in the vicinity of the Rawlins quadrangle, Nyoming.

The vegetation in the area is altitudinally zoned. The basins are covered by short grasses and sageorish, with the soil containing little organic matter. There is a zoise of pinon and juniper trees on tine lower slopes of the mountain canges with a zone of yellow pine and Douglas fir above that. At the higher elevations, these grade into Iodgepole pine and aspen. Just below the timberline is a zone of Englemann spruce and various firs; above it, the vegetation consists of small herbs and grasses with much of the ground bare (Hunt, 1974).

Rawlins is the largest city in the quadrangle with a 1973 population of about 8900, followed by Saratoga, Hanna, Medicine Bow, and Sinclair. Approximately $54 \%$ of the land is federally-owned, $39 \%$ is privately-owned, and $7 \%$ is held by the state (State of Wyoming, 1975, figures for Carbon County). 
The climate of the Rawlins NTMS quadrangle area is semiarid, very windy, and cool. The average annual precipitation varies from above $800 \mathrm{~mm}$ in the higher elevations of the Sierra Madre and the Medicine Bow Mountains to less than $250 \mathrm{~mm}$ in the valleys and less than $180 \mathrm{~mm}$ in the Great Divide Basin. About half of the annual precipitation occurs in late spring and summer when the prevailing westerly winds diminish and zllow northerly or southerly winds to bring moisture into the area. The large amounts of rainfall near the moluntains result from thermally induced thunderstorms.

Winter temperatures average just above $0^{\circ} \mathrm{C}$ for highs and around $-10^{\circ} \mathrm{C}$ ior lows; summer high temperatures average about $30^{\circ} \mathrm{C}$ and lows are near $5^{\circ} \mathrm{C}$. Duriag both sampling contracts, the temperature was slightly warmer than average and there was normal to slightly less than average precipitation. Samplers recorded the weather conditions at each sample location; these data are insluded in Appendixes $B$ and $C$. Additiona? information on the climate of the Rawlins NTMS quadrangle i.s provided in Becker and Alyea (1964a; 1964b) and in reports by the National Oceanic and Atmospheric Administration (1975; 1977 ).

\section{GEOLOGY}

\section{Regional Setting}

The Rawlins NTMS quadrangle is situated entinely within the Rocky Mountain system of which the Wyoning basin and Southern Rocky Mountains are parts. A geologic map (1:250 000-scale) of the study area is shown on Plate [. Dther geologic maps of this area have been compiled by Welder and McGreevy (1965) and Lowry et al (1973). The geologic history of south-central Wyoming has been treated by Thomas (1949), Houston (1969), and 3lackstone (1971; 1975) and is discussed only briefly below.

\section{Structure}

The Sierra Madre and the Medicine Bow Mountains are asymmetric anticlinal uplifts with Precambrian cores of granites and metasediments flanked by Paleozoic and younger strata. They were uplifted during the Laramide orogeny (late Cretaceous to early Tertiary) and were glaciated during the Pleistocene. The Rawlins uplift also took its present structural form during the Laramide orogeny, though now the area is a shallow, topographic and hydrologic basin.

The northeast-trending Mullen Creek-Nash Fork shear zone, a major tectonic lineament, cuts through the Sierra Madre and the Medicine Bow ilountains. It marks the southern edge of Precambrian units older than $2.5 \mathrm{~b} . \mathrm{y}$. and may be a boundary between two major Precambrian geologic provinces (Houston et al, 1968; Houston, 1971).

The Wyoming basin is composed of several smaller structural basins which in many cases have ill-defined topographic boundaries. The individual basins in the study area are the Great Divide (or Red Desert), Hanna, Carbon, Laramie, Saratoga, and Washakie basins (Fig. 2). These basins typically are filled with several thousand meters of sediments; the lower sequences are Paleozoic and Mesozoic marine strata deposited before the basins former, and the upper sequences are late Cretaceous and Tertiary sediments derived from the surrounding uplifted areas. 
A generalized stratigraphic column from the Rawlins area is shown on Plate $\mathrm{I}$. The Nyoning Geological. Association has standardized the stratigraphic nomenclature is the state and their stratigraphic columns for Rawlins and other areas in Wyoming are found in Barlow (1969). The Paleozoic and early Mesozoic strata are generally thin (a few tens to a fow hundreds of meters ticick). The upper Cretaceous and lower Tertiary strata are thicker (hundreds to greater than $1000 \mathrm{~m}$ ), with the Paleocene Hanna formation exceeding $4000 \mathrm{~m}$ in some locations. Late Tertiary and Quaternary deposits are relatively thin (less than a few hundred meters tinick).

While uranium has been found in virtually every major stratigraphic unit in Wyoming (Finnell and Parrish, 1958), currently, the most economically important deposits occur in formations of early Eocene age (Houston, 1969). Most investigators consider the principal uranium sources for these Tertiary deposits to be oither Tertiary volzanic debris that once covered much of Wyoming or the Precambrian granites in the Granite, Ferris, Seminoe, Freezeout, Snirley, and Pedro Mountains just north of the study area and in the Laramie Mountains east of the study area. Formations present in the siudy area which have been reported to contain mineable uranium elsewhere in Nyoming are: tie Mississippian Madison limestone; the Triassic Chugwater group; the Jurassic Morrison formation; the Cretaceous Cloverly, Mesaverde, Lance, and Medicine Bow formations; and the Tertiary Fort Union, Wind River, Wasatch, Green River, North Park, and Browns Park formations (Finch, 1967).

The North Park and Browns Park formations cover zpproximately $6000 \mathrm{~km}^{2}$ in the central and south-central portions of the study area and are associated with the majority of the uranium occurrences (described below) in those areas. The North Park formation is composed of interbedded, fine- to mediumgrained sandstone and siltstone, cherty limestone, marlstone, and volcanic ash. Locally, the sandstone grades to thin, dense limestone. The Browns Park formation is similar to the North Park formation but is of ten associated with a tinick basal conglomerate. Since these two formations are so similar, their differentiation is often questionable (Stephens and Bergin, 1959; Vine and Prichard, 1959). Most uranium occurrences in the North Park and Browns Park formations are associated with silicified limestone beds.

Hydrology

The Rawlins NTMS quadrangle-includes five major drainage basins. Three are east of the Continental Divide and a rourth is west of it; the fifth is the Great Divide Basin, a closed hydrologio basin in the northwest section of the quadrangle that is enclosed by the two branches of the Continental Divide. The largest part of the study area is drained by the North Platte River which flows northward through the central part of the area from Colorado. The northeast portion of the area is drained to the north by the Medicine Bow River; the southeast, to the east by tributaries of the Laramie River; and the southwest, to the west by tributaries of the Little Snake River. Many tributaries of the larger rivers which have their headwaters in the higher elevations of the Sierra Madre or the Medicine Bow Mountains are perennial streams. Other tributaries and smaller streams in the lower elevations are dry most of the year. Over the entire area, much of the precipitation, surface water, and soil moisture is lost to the atmosphere by evaporation or transpiration.

Surface waters in the mountains are of a calcium bicarbonate type with moderately low concentrations of dissolved solids. In the lower elevations, 
where a significant portion of the water inflow to streams is through soils, the waters are a calcium or calciun-sodium sulfate type; at low stream flow rates, such waters have moderately high concentrations of dissolvod solits. In nost parts of the study area, ground water is available in sufficient, quantities ïrom shallow weils. The silght fluctuation of water levels is well:s indicates a good balance between the discharge and recharge systems of the ground water reservoirs. The main discharges are from seepago into lakes, nivers, and streams, pumpage of wells, and underflow through aquifers that, extend out of the area. Recharge is mainly from precipitation and chiefly occurs in the mountainous regions. The predoninant use of ground water is for watering livestock and a small number of wells are used for domestic or commercial water supplies. Some wells in the Saraloga valiey are used for irrigation. Artesian wells and springs can be found througholdt the area; sevoral of each were sampled during this reconnaissance.

The ground water quality differs greatly throughout the stury area, even within a given aquifer. Calcium bicarbonate waters, low in dissolved solids, are most abundant, iz shallow wells and springs in recharge areas. Caloium bicarbonate and calciur sulfate waters, jigh in dissolved sol.ids, are more common at greater depths or at greater distances from the recharge areas. Waters that have been in the aquifers for even greater distances (typically deep aquifers) are also usually high in sodium. Summaries of the Nater quality and the water-produsing potential of many geologic formations in the area are given in Welder and McGreevy (1965) and Lowny et al (1973).

Uranium Occurrences

In 1975, Wyoming produced 4400 tons of $\mathrm{U}_{3} \mathrm{O}_{8}$ (31\% of the total US production for that year). The major producing areas in wyoning (the Gas Hills, Crooks Gap, and Shirley Basia distriets) are locatad just north of the study araz. Present production in the state is from Tertiary arkosic sandstones of the Wind River and Battle Springs formations. 4 thorough review of the uranium geology, uranium districts, and areas of uracium mineralization in Wyoming is given by Elevatorski (1975). A review of the geology of uranium deposits in sandstones in the United States is given by Finch (1967).

In the Rawlins quadrangle there are one uranium district, several areas of uranium xineralization, and one area that has two radiometric anomalies for which no uranium mineral occuryence has been reported. These areas are discussed below (roughly in decreasing order of significance), listed in Table $I$, and mapped on Plate IV. The capj.tal letters in parentheses following occurrence names in the text correspond with those in Table $T$ and on Plate IV.

The rajority of the occurrences in the central and soutiwestern portions of the study area are associated with either the North Parik or the Browns Pank formations, where airborne radiometric surveys have indicated numerous anomalies (Mazleby and Mallory, 1954; Ormand, 1957; Stephens and Bergin, 1959; and Vine and Prichard, 1959). Four groups of anomalies--the Poison Basin uranium distriat (A), the Ketchum Buttes area (B), the Miller Hill area (C), and the Saratoga area (D)--are associated with uranium mineralization. A fifth area, the Crescent Group ( $(5)$, was not identified as anomalous during the airborne radiometric surveys, but was found to have uranium mineralization in the basal conglomerate of the Browns Park formation.

In the Poison Gasin district, the uranium sccurs in the Browns Park formation in both an upper, oxidized zone and a lower, unoxidized zone. The uranium minerals in the oxitized zone are uranophane, meta-zutunite, schroeckingerite, and uranyl vanadates; those in the unoxidized zone are coffinite 
TABLE I

REPORTED URANIUM OCCURRENCES IN THE RAWLINS QUADRANGLE

ID $^{a}$ Name

A. Poison Basin District

B. Retchum Buttes Area

C. Miller Hill Area

D. Saratoga Area

E. Crescent Group

g. Great Divide Basin Area

G. Doane-Rambler Mine

B. Big Creek Area

I. Lake Resort Area

J. Reystone Area

R. Libby Creek Area

L. Rock Creek Area

M. Unnamed

N. Unnamed

o. Unnamed

P. Sunset No. 1 Clalm

Q. Lucky Annie Claim

R. Unnamed

S. Unnamed
Lat 1tude

$41^{\circ} 03^{\prime} \mathrm{N}$

Longitude

$107^{\circ} 47^{\prime} \mathrm{H}$

$41^{\circ} 15^{1 N}$

$107^{\circ} 24^{\prime} 4$

Carbon

$41^{\circ} 25^{\prime N}$

$107^{\circ} 15^{\circ}$

$41^{\circ} 25^{\prime N}$

$106^{\circ} 52+4$

Carbon

Carbon

$41^{\circ} 04^{\prime N}$

$41^{\circ} 50^{\prime} \mathrm{N}$

$41^{\circ} 09^{\prime}$

$41^{\circ} \mathrm{OT}$ 'N

$106^{\circ} 29$

Carbon

$\begin{array}{lll}41^{\circ} \mathrm{O} 7^{\prime N} & 106^{\circ} 14^{\prime} \mathrm{W} & \text { Albany } \\ 41^{\circ} 11^{\prime} \mathrm{N} & 106^{\circ} \mathrm{O} \cdot \mathrm{W} & \text { Albany }\end{array}$

$$
41^{\circ} 19^{\prime} \mathrm{X}
$$

$106^{\circ} 10^{\prime} \mathrm{W}$

Albany

$$
41^{\circ} 35^{\prime} \mathrm{x}
$$

$106^{\circ} 14^{\prime H}$

Carbon

$41^{\circ} 15^{\prime} \mathrm{K}$

$107^{\circ} 06^{14}$

$41^{\circ} 34^{\prime} \mathrm{N}$

$106^{\circ} 12^{\prime ห}$

$41^{\circ} 34 ' \mathrm{~N}$

$106^{\circ} 11 \cdot 4$

$41^{\circ} 47^{\prime} \mathrm{N}$

$107^{\circ} 24 \cdot \%$

$41^{\circ} 50^{\prime N}$

$106^{\circ} 47^{\prime}$

$41^{\circ} 53^{\prime} N$

$106^{\circ} \mathrm{O} 2^{\prime}$

Albany

$41^{\circ} 59^{\prime} \mathrm{N}$ $106^{\circ} 08^{\circ}$
Carbon

Carbon
Comments

Uranophane, meta-autunite, schroeckingerite, coffinite, and uraninite in Broins Park fm. Past production.

Oranophane associated whth the silicic ifmestone members of Horth Park fm. Past production.

Same as above.

Camotite coatings in sandstones and limestones of North Park and Browns Park fus.

Uranium mineralization in basal conglomerate of Broms Park fu.

Uranium in low-grade coals of Hasatch and Battle Springs fms.

Oranium mineralization in malachite-bearing quartzite.

Precambrian pegmatites containing copper, rare earth and thorius minerals and associated uranium oxide.

Uranium in Precambrian granodiorite.

Oranium mineralization in Precambrian quartz monzonite and paragnetss.

Uranium mineralization in Precambrian biotite schist.

Uranium in quartz monzonite and orthognelss.

Uranium in weathered Precambrian conglomerates.

Same as above.

Same as above.

Uranium mineralization in arkosic sandstone of Fort Union for.

Uranium mineralization in sandstone (?) of Medicine Bow fa.

Airborne radiowetric anowaly--no uranium mineralization reported. Same as above.

\footnotetext{
Ocourrence IDs correspond to those in text and on Plate IV.
} 
and uraninito. Ore from this area ranges in grade from $0.004 \%$ to $3.2 \%$ $\mathrm{U}_{3} \mathrm{O}_{8}$; estimated reserves in the distriet are 540 metric tons (1.2 million pounds) of $\mathrm{U}_{3} \mathrm{O}_{8}$. Significant amounts of selenium, vanadium, and molybdenum are also present in the Poison Basin area (Elevatorski, 1976). In the Ketchum Buttes and Miller Hill areas, dranophane commoniy is found disseminated $i_{1}$ the freshwater limestone members of the North Park formation, coating fractures and filling viggs (Vine and Prichard, 1959). In the Saratoga area, carnotite occurs at numerous claims as a coating on limestore and sandstone grains in both the North Park and Browns Park formations and also as a coating on Quaternary gravels (Stephens and Bergin, 1959).

In the Great Divide Basin area (F), low-grade uranium concentrations are found in coal, lignite, and carbonaceous shales of the Tertiary Wasatch and Battle Springs formations (Wyant et al, 1956; Masursky and Pipiringos, 1959; Masursky, 1952). Tho average uranium content of the carbonaceous materia? in this area is approximately $0.03 \% \mathrm{U}_{3} 08$; concentrations as high as $0.05 \%$ $\mathrm{U}_{3} \mathrm{O}_{8}$ are reported for impure coals from Creston Ridge (Masursky, 1962).

Flevatorski (1975) reports several uranium occurrences in the Precambrian rocks of the Sierra Madre and the Medicine Bow Mountains. A sainple from the dump at the Doane-Rambler mine (G) had uranium in a malachite-bearing quartzite. The Big Creek area (H), on the western flank of the Medicine Bow Mountains, has Precambrian pegmatites which have been mined for copper and rare earth minerals since 1956. Uranium oxide and thorium in monazite have been found in these pegmatites (Wilson, 1950; Houston, 1961). Uranium has also been found in the Medicine Bow Mountains in: granodiorites in the Lake Resort area ( $I$ ), quartz monzonite and paragneiss in the Keystone area $(J)$, biotite schist in the Libby Creek area $(K)$, and quartz monzonite-orthogneiss in the Rock Creek area (L). Graff and Houston (1977) report one unnamed loo3tion in the northwestern Sierra Madre $(M)$ and two unnamed locations in the eastern Medicine Bow Mountains ( $N$ and $D$ ) where weathered Precambrian conglomerates have $>100$ parts per million (ppm) uranium, but no mention is made of the form of the uranium at any of these three locations.

Uranium mineraiization has also been reported at the Sunset No. 1 claim (P) and at the Lucky Annie claim (Q), both in the northern part of the study area. The host rocks for the uranium at these two claims are an arkosic sandstone of the Fort Union formation and a sandstone (?) of the Medicine Bow Conmation, respectively (Elevatorski, 1976).

Two localities ( $(\mathrm{)})$ and $(S)$, in the northeastern portion of the Rawlins quadrangle, were identified as airborne radiometric anomalies by Shannon and Ruzycki (1957). Their follow-up ground investigations of these anomalies found no areas of uranium mineralization.

In addition to the Poison Basin district, which was mined intermittentiy from 1954 to 1963, minor uranium production has been reported for the Ketchum Buttes, Miller Hill, and Big Creek areas. In December 1975, Urangesellschaft IJSA announced plans to further develop the reserves in the Poison Basin area (Elevatorski, 1976).

TV. ANALYTICAL AND STATISTICAL DATA FOR URANIUM CONCENTRATIONS IN WATER AND SEDIMENT SAMPLES

During this reconnaissance, 570 water samples and 1281 sediment samples were collected and analyzed using the standard procedures outlined in Appendix A. Listings of field data and measured uranium concentrations for water 
samples are given in Appendix B; similar listings for sediment samples are ziven in Appentix C. All uranium concentrations in waters are reported as parts per billion (pph) in this report and all uranium concentrations in sedinents are reported as ppm. Appendix $D$ gives an explanation of the code used in the data listings and $a$ key to the sample types. The sample location overlay is presented on Plate II; uranium concentration overlays for water and seciment samples are shown on Plates III and IV, respectively. All overlays are plotted at 1:250 000 scale and may be used with both tine Aawlins NTMS map sheet and the geologic map of the Rawlins quadrangle (Plate I). The LASL sample location numbers printed on Plate II differ from those used in the text and in Appendixes $B$ and $C$ only in that the leading two alphanumeric characters and any subsequent leading zeros have been dropped from the location numbers priated on the plate (e.g., location 120038 in the Appendixes would appear as 38 on Plate II). The numbers printed next to the symbols for the two largest: concentration intervals on the concentration overlays are the measured uranium concentrations (in the appropriate units) for tiose samples, truncated to integer valie.

\section{Uranium Concentrations in Water Samples}

A histogram of îrequency versus uranium concentration for all water samples is given in Fig. 3. Table II presents the number of samples, maximum and minimum values, mean value $(\bar{x})$, and standard deviation ( $\sigma$ ) for uranium concentrations in all water samples; for comparison only, Table II also contains the same information for each water sample type. Three distinct groups of water sample types, in order of decreasing uranium content, are: natural ponds, ground waters (welis and springs), and other surface waters

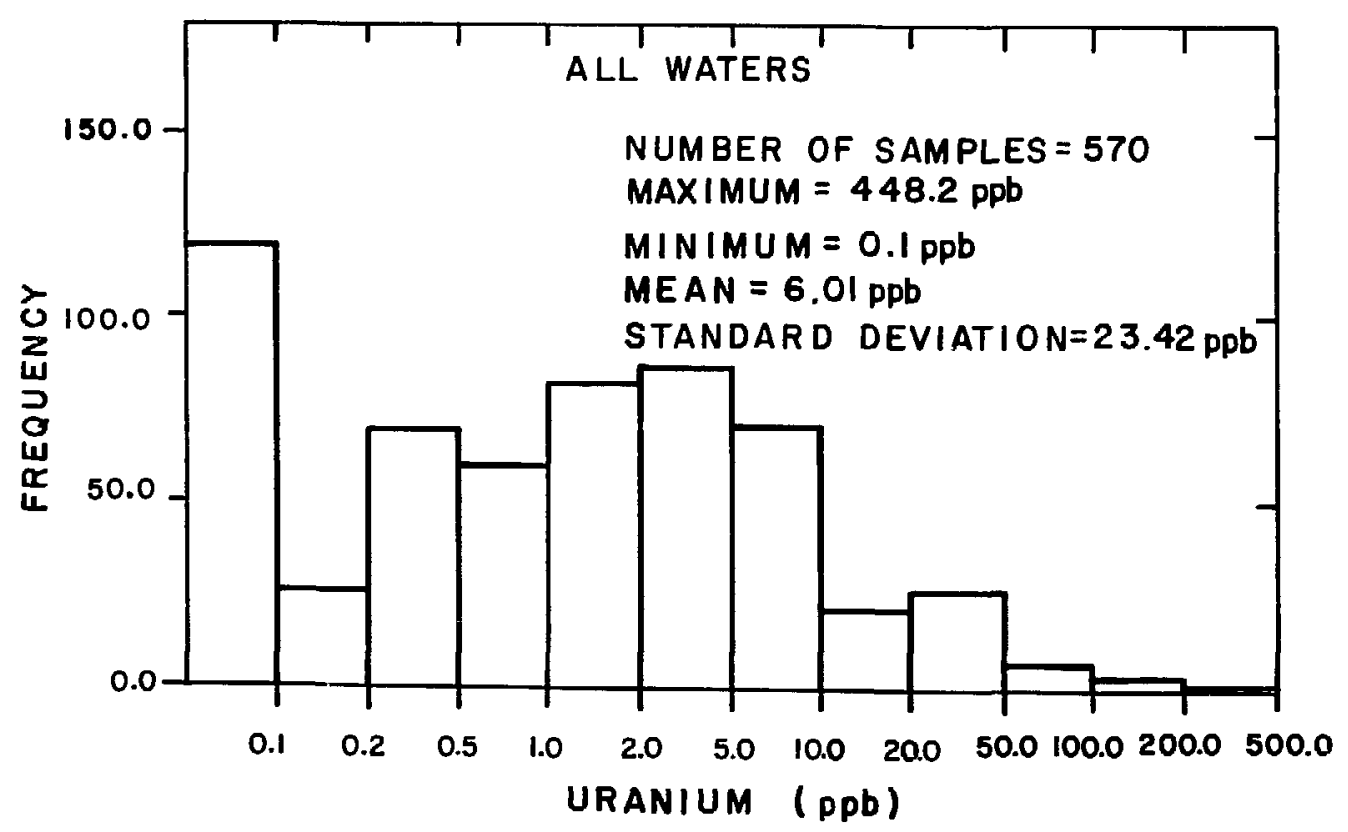

Eig. 3. Histogram of the uranium concentrations in waters from the Rawlins quadrangle, Wyoning. 


\section{SUMMARY OF URANIUM DATA FOR WATER SAMPLES COLLECTED}

IN THE RAWLINS QJADRANGLE

\begin{tabular}{|c|c|c|c|c|c|}
\hline $\begin{array}{l}\text { Sample } \\
\text { Type } \\
\end{array}$ & $\begin{array}{c}\text { Number of } \\
\text { Samples } \\
\end{array}$ & $\begin{array}{c}\text { Minimum } \\
\text { (ppb) } \\
\end{array}$ & $\begin{array}{c}\text { Yaximum } \\
(\mathrm{ppb}) \\
\end{array}$ & $\begin{array}{l}\text { yean } \\
\text { (ppb) }\end{array}$ & $\begin{array}{l}\text { Standard } \\
\text { Deviation }\end{array}$ \\
\hline All Waters & 570 & 0.10 & 448.2 & 6.01 & 23.42 \\
\hline All Waters ${ }^{a}$ & 569 & 0.10 & 153.3 & 5.23 & 14.30 \\
\hline Streams & 385 & 3.10 & 135.8 & 3.23 & 9.54 \\
\hline Springs & 33 & 0.10 & 153.3 & 7.19 & 13.38 \\
\hline Artificial Ponds & 50 & 2.10 & 33.7 & 5.80 & 8.71 \\
\hline Natura? Ponds & 35 & 0.10 & $448 . ?$ & 32.37 & 78.89 \\
\hline Natidral Pond a & 34 & 0.10 & 123.2 & 20.14 & 31.90 \\
\hline Wells & 17 & 0.19 & 81.8 & 9.58 & 20.06 \\
\hline
\end{tabular}

a For statistical comparison, the one water sample from a natural pond with 449.2 ppb uranium has been exeluded in these compilations only.

(artificial ponds and streams). However, due to the 1 imited charter for statistical analysis and interpretation in tiis program, only the statisicics for the total water population will be considered below.

An arbitrary anomaly threshold for waters has been set at 50 ppb uranium, which corresponds to roughly $\bar{x}+20$ for all water samples taken from the Rawlins quadrangle during this study. This threshold value is subjective, as the eljomination of only one water value, $448.2 \mathrm{ppb}$ uranium from a natural pond, would lower the $\vec{x}+2 \sigma$ to approximately 34 ppb (Table II). In view of this subjectivity, $\exists l 1$ water sanples with uranium concentrations $\geq 20$ ppb have been examined and are discussed below, particularly with respect to their relationship to the "anomalous" samples. Table III provides relevant data for the 11 water samples with uranium concentrations above the anomaly threshold. of these 11, only one corresponds to a known uranium occurrence (well sample W21100 from the Great Divide Basin area). Of the remaining 10,8 cluster in the very northeastern corner of the quadrangle (Plate III), in the drainage area of the Medicine Bow River. The other two are along the edge of the Rawlins uplift, north and west of Rawlins.

Twenty-six samples are in the uranium concentration interval directly below the arbitrarily chosen anomaly threshold ( $>20 \mathrm{ppb}$ and $\leq 50 \mathrm{ppb}$ ) on Plate III. Ten (three natural ponds, two artificial ponds, two streams, two springs, and one well) are from the Medicine Bow River drainage area. Another seven are from the Saratoga and Miller Hill occurrence areas (six samples and one sample, respectively), which are underlain by the Browns Park/North Park formations. The remaining nine samples in this subanomalous interval are scattered throughout the quadrangle. 
RELEVANT DATA FOR WATER SAMPLES WLTH URANIUM CONCENTRATIONS ABOVE AN ARBITRARY ANOMALY THRESHOLD OF 50 PPB

\begin{tabular}{|c|c|c|c|c|c|}
\hline $\begin{array}{l}\text { LASL } \\
\text { Location } \\
\text { Number } \\
\end{array}$ & $\begin{array}{c}\text { Sample } \\
\text { Type }\end{array}$ & $\begin{array}{l}\text { Total } \\
\text { Tranium } \\
\text { (ppb) } \\
\end{array}$ & $\mathrm{pH}$ & $\begin{array}{c}\text { Specific } \\
\text { Conductance } \\
(\mu \text { mhos/cm) }\end{array}$ & $\begin{array}{l}\text { Sample } \\
\text { Location } \\
\text { Description }\end{array}$ \\
\hline พ20349 & Stream & 53.7 & 6.9 & 27000 & $\begin{array}{l}\text { East of the town of Elk Mountain } \\
\text { in drainage from an area where } \\
\text { the Mesaverde } \mathrm{fm} \text {. crops out }\end{array}$ \\
\hline W21204 & Natural Pond & 61.8 & 7.5 & 4400 & Separation Lake \\
\hline W21151 & Stream & 70.6 & 8.1 & 75 & $\begin{array}{l}\text { Muddy Creek; drainage from an area } \\
\text { where the Morrison and Chugwater } \\
\text { fms. crop out }\end{array}$ \\
\hline W20530 & Natural Pond & 73.1 & 8.6 & 50000 & Soutbwest of Nelson Ranch \\
\hline W21100 & Well & 81.8 & 7.3 & 2100 & Great Divide Basin area \\
\hline W21190 & Natural Pond & 95.5 & 8.6 & 5000 & Como Lake \\
\hline W21155 & Natural Pond & 96.1 & 9.0 & 5000 & Pynch:n Lake \\
\hline W20353 & Natural Pond & 123.2 & 8.1 & 50000 & Willow Springs Draw \\
\hline H2OB 12 & Stream & 135.8 & 7.6 & 1155 & Little Medicine Bow River \\
\hline W21218 & Spring & 153.3 & 9.5 & 1200 & Along Cherokee Creek \\
\hline W21166 & Natural Pond & 448.2 & 8.9 & 5000 & South of Sand Creek \\
\hline
\end{tabular}

The broad cluster of sight anomalous and ten near-anomalous water samples from the Medicine Bow River drainage area in the northeastern corner of the quadrangle is assosiated with no known urazium mineral occurrences; however, two airborne radiometric anomalies found by Shannon and Ruzycki (1957) occur in this general area. This cluster is underlain by moderately complex geology with numerous dissected anticlines that expose Paleozoic through upper Cenozoic strata (Plate $I$ ), and there is no clear correlation between specific stratigraphic units and uranium concentration. All anomalous water samples and most water samples with uranium concentrations $>20 \mathrm{ppb}$ in this area are from ponds and streams. Fix (1956) points out that evaporation in arid climates and other factors can increase the uranium content of sti.1 waters by two or more orders of magnitude. For this reason, pond waters containing high uranium concentrations should be evaluated with caution. However, eight samples (one from a well, two from springs, and five from streams) Erom the area have uranium concentrations in excess of $20 \mathrm{ppb}$, indicating that both surface waters and ground waters in the Medicine Bow drainage area contain uranium concentrations significantly higher than the mean for waters in the Rawlins quadrangle.

Again, it should be noted that the arbitrary anomaly threshold for water samples has been set at a rather high level ( $>50 \mathrm{ppb}$ uranium). This was done for co:lvenience of data presentation. The further detalled evaluation of data from water samples containing considerably less uranium than this arbitrary anomaly threshold may be beneficial to a uranium resource assessment program. 
A frequency versus uranium concentration histogram for all 1231 sedjment samples from the Rawlins quadrangle is given in Fig. 4. Table IV is a simmary of uranium statistical data for all sediments and for each sedinent, sampie type. Sediments from natural ponds contain significantly more uranium tinan any other sediment sample type; however, only the statistics for the total. sediment population will be considered below. The 22 samples designated "other," indicated by a 99 in the Sample Type ifield in Appendix 5, are dryspring sediments that ave been dried and sieved to -100 mesh.

An arbitrary znomaly threshold for sediments has been set at 7 ppm uranium, approxinately $\bar{x}+2$ for all sediment samples. Relevant data for tine I4t anomalous sediment sanples are shown in Table $V$. Of these, 25 san be associated with known uranium minerai occurrences: 14, with the Great Divide Basin; 5, wjth the Poison Basin 1istrict; 4, with the Baratoga area; and ?, witi the Miller Hill. area. The najority of the sediment samples in the vicinity of the Treat Divide Basin and Poison Basin anomalous sample clusters have uranium concentrations that are siznificantly above background for their respective areas. On the other hand, only a rew samples from the Saratoga and liller Hill areas ane anomalous or well above the background.

The 14 anomalous samples from the Great Divide Basin form a broad cluster, as does the Great Divide Basin jccurrence area itself. Associated with these anomalous samples are 23 subanomalous samples with uranium concentrations is the interval from 7 to 9 ppm. This entire area is underlain by the Battle Springs and Jasatch formations, both of which contain uraniferous, low-grade coal.

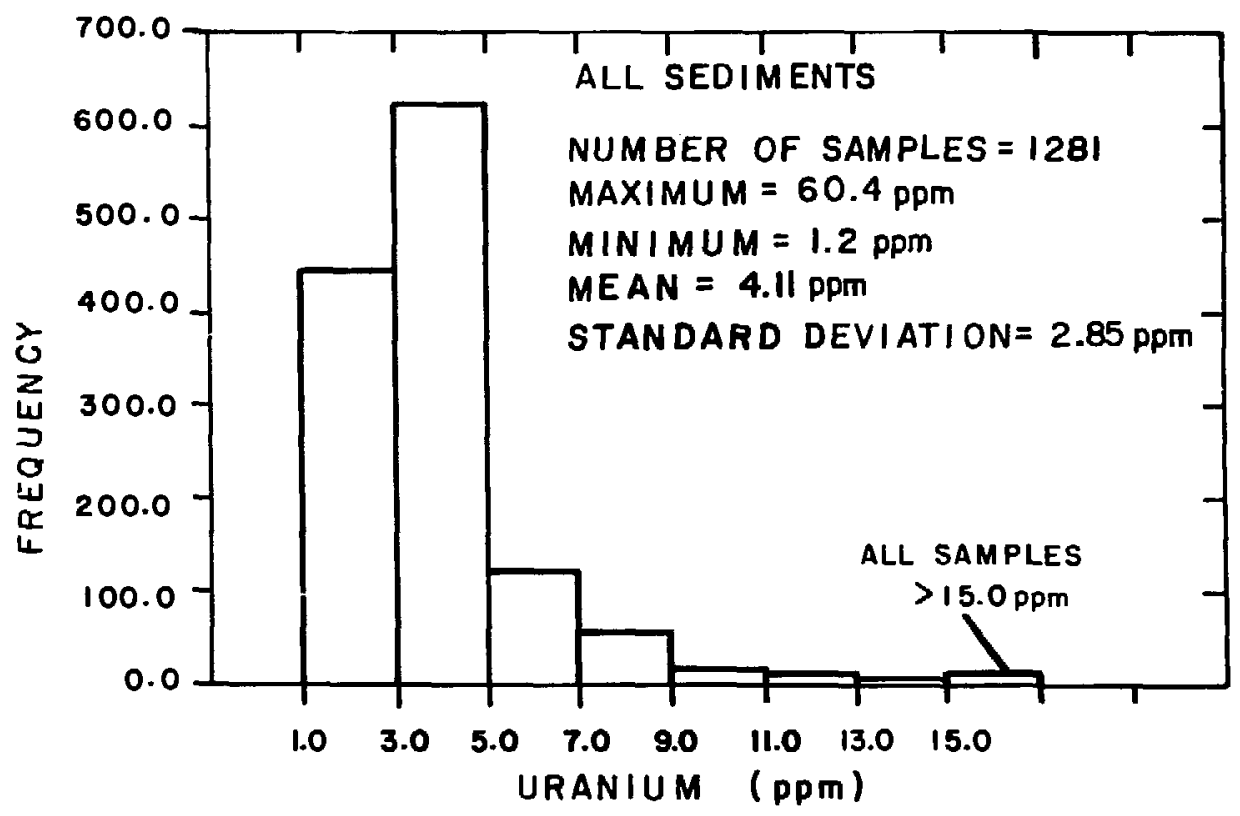

Fig. 4. Histogram of the uranium concentrations in sediments from the Rawlins quadrangle, Wyoming. 
SUMMARY OF URANIUM DATA FCR SEDIMENT SAMPLES COLILETED

IN THE RAWLINS QUADRANGLE

\begin{tabular}{|c|c|c|c|c|c|}
\hline $\begin{array}{c}\text { Sample } \\
\text { Type } \\
\end{array}$ & $\begin{array}{l}\text { Jumber of } \\
\text { Samplee }\end{array}$ & $\begin{array}{c}\text { Minimum } \\
\text { (ppm) } \\
\end{array}$ & $\begin{array}{c}\text { Maximum } \\
\text { (ppm) } \\
\end{array}$ & $\begin{array}{l}\text { Mean } \\
\text { (ppm) }\end{array}$ & $\begin{array}{l}\text { Standard } \\
\text { Deviation }\end{array}$ \\
\hline All Sediments & 1281 & 1.2 & 60.4 & 4.11 & 2.85 \\
\hline Dry Streams & 663 & 1.2 & 32.3 & 3.96 & 2.23 \\
\hline Wet Streams & 327 & 1.5 & 22.4 & 4.01 & 2.22 \\
\hline Wet Springs & 74 & 1.5 & 12.5 & 4.25 & 2.27 \\
\hline Dry Natural Ponds & 63 & 1.2 & 24.3 & 5.17 & 3.80 \\
\hline Dry Artificial Ponds & 51 & 1.9 & 10.7 & 3.95 & 1.54 \\
\hline Wet Artificial Ponds & 49 & 1.8 & 7.8 & 3.83 & 1.49 \\
\hline Wet Natural Ponds & 32 & 2.1 & 60.4 & 6.80 & 10.69 \\
\hline Dther (Dry Springs) & 22 & 1.9 & 13.2 & 3.76 & 2.27 \\
\hline
\end{tabular}

None of the rive anomalous samples associated with the Poison Basin district and only one of the four from the 3aratoga area fall within the areal boundaries defined by the known uranium occurrences. The five Poison Basin anomalous samples are from dry streams that drain the Poison Basin to the west; the sample with the highest uranium concentration (32 ppm in sediment sample W20951) was taken from a dry wash just outside the occurrence area (see plate IV). Three of the 3aratoga area anomalous samples are from just outside the area defined by the known uranium occurrences. Two of these are from wet streams south of the occurrence area which flow into, not out of, the occurrence area (W20121 with $18 \mathrm{ppm}$ and W21364 with $20 \mathrm{ppm}$ uranium).

Three of the remaining anomalous sediment samples are from the Medicine Bow River drainage area discussed in the previous section. Also associated with this area are six subanomalous samples witi uranium contents in the interval 7 to 9 ppm; however, the majority of the sediment samples in this area have uranium contents of $<5 \mathrm{ppm}$.

Three other anomaly clusters are worthy of note: 7 cluster of three anomalous samples from along the Encampment River and its tributary, Miner Creek, in the Sierra Madre; $a$ cluster of three anomalous samples from Mullen Creek and Savage Run Creek in the Medicine Bow Mountains; and a small cluster of two anomalous samples from Gramm Creek in the Medicine Bow Mountains. The area around the Encampment River/Miner Creek cluster also contains six subanomalous samples with uranium contents in the interval 7 to $9 \mathrm{ppm}$. The Mullen Creek'Savage Run Creek samples are from an area along the Mullen CreakNash Fork shear zone. There are no other samples in the vicinity of Gramm Creek. All three clusters are along drainages irom areas where Precambrian gneisses and granites crop out; however, no uranium mineral occurrences are known in these drainage areas.

The remaining eight anomalous samples, not discussed above, are widely scattered over the Rawlins quadrangle and may or may not be significant. 


\section{RELEVANT DATA FOR SEDIMENT SAMPLSS WITH URANIUM CONCENTRATIONS ABOVE AN ARBITRARY ANOMALY THRESHOLD OF 9 PPM}

LASL

Location

Number

W20671

W20249

421119

W20140

H21115

W21116

พ21033

H20654

พ20129

H20840

พ20953

W21052

К20139

พ20404

H21051

W20748

W20998

W21322

H20508

K21099

พ21206

\$21105

พ21117

H211ลิ7

พ21101

พ21323

พ20760

H20902

พ20978

K20001

420256

W21096

K21172

พ20837

พ20121

พ20981

พ21099

พ20954

H21090

$\$ 21364$

H20130

พ21093

W20951

พ204 is
Total

Uraniun (pps)

Wet Spring

Het Stream

Dry Natural Pond

Dry Stream

Dry Strean

Dry Natural Pond

Dry Stream

Wet Spring

Het Stream

Wet Natural Pond

Dry Stream

Dry Jatural pord

Wet Stream

9.3

9.4

9.5

9.6

0.6

9.6

9.7

Dry Artificial Pond 10.7 Dry Natural Pond 10.7

Dry St,ream $\quad 11.0$

Dry Stream $\quad 11.2$

Het Spring $\quad 11.2$

Wet Stream $\quad 11.3$

Dry Stream 11.3

Wet Spring $\quad 11.5$

Dry NaturaL Pond 12.1

Dry Natural Pond 12.4

Dry Stream 12.4

Dry Stream 12.5

Het Spring $\quad 12.6$

Wet Stream $\quad 12.8$

Dry Spring $\quad 13.2$

Dry Stream 13.2

Dry Stream $\quad 13.8$

Dry Stream

Wet. Natural Pond

Dry Natural Pond

Dry Stream

Wet Stream

Dry Strean

Wet Natural Pond

Dry Stream

Wot Natural Pond

het Stream

Wet Strean

Dry Natural Pond

Dry Stream

Wet Naturai Pond
14.4

14.5

15.9

17.0

18.4

18.5

18.5

13.9

19.1

19.9

22.4

24.3

32.3

60.4

\section{Sample Location Description}

Cottonwood Rim

Mullen Creek; along Mullen Creek-Nash Fork shear zone in the Medicine Bow Mountains

Great Divide Bzsin area

Savage Run Creek; drafnage from an area in the Medicine Bow Mountains where Precarbrian gnelsses and granites crop out Great Divice Basin area

Great Divide Basin area

Near the town of New Jelm; drainage fror an area in the Medicine Bow Mountaing where Precambrian gneisses and granttes crop out

Along Dutah Joe Creek

Gramm Creek; drainage from an area in the Medicine Bow Mountains where Precambrian gneisses and granites crop out Foote Creek Lake

Poison Basin area

Great Divide Basin area

Mullen Creek; along Mullen Creek-Nash Fork shear zone

in Medicine Bow Mountains

Saratoga area

Great Divide Basin area

Near the town of Rawlins

Blue Gap Draw

Along Encampment River in the Sierra Madre Mountains

South Fork of Miner Creek in the Sierra Madre Mountains

Great Divide Basin area

Miller Hill area

Great Divide Basin area

Great Divide Basin area

Great Divide Basin area

Great Divide Basin area

Along Encampment River in the Slerra Madre Mountains

Buckeye Creek

Miller Hill area

Poison Basin area

South of Doty Mountain; other sediment samples in the

immediate area are much lower in uranium content

Fingerle Hollow

Great Divide Basin area

Kinney Reservoir

Headwaters of Foote Creek

Saratoza area

Poison Basin area

Great Divide Basin area

Poison Basin area

Great Divide Basin area

Saratog 3 area

Gramm Creek; drainage from an area in the Medicine Bow

Mountains where Precambrian gneisses and granites crov out

Great Divide Basin area

Poison Basin area

Saratoga area 
A iotal of 570 natural water samples and 1281 waterborne sediment samples from 1361 locations in the Rawlins NTMS quadrangle were collected and analyzed for total uranium content. An arbitrary anomaly threshold was selected for both the water and the sediment uranium content distributions; in each case, the threshold was set at approximately the mean plus two standard deviations for their respective total population. This resulted in 11 water anomalies and 44 sediment anomalies $(1.9 \%$ and $3.4 \%$ of the total water sample and sediment sample populations, respectively).

The Rawlins quadrangle contains 17 areas of known uranium mineral occurrence and two additional areas that have been identified from the literature as airborne radiometric anomalies for which no corresponding uranium mineralization is known. Only one anomalous water sample can be associated with a known uranium occurrence (a well water sample from the Great Divide Basin). However, eight anomalous water samples can be associated with the Medicine Bow Rivor drainage area in the northeastern part of the quadrangle, which also contains two airborne radiometric anomalies. Samples from the concentration interval immediately below the arbitrarily chosen anomaly threshold can be associated with two other uranium occurrence areas, the Saratoga and Miller Hill areas. In addition, 10 water samples from this interval are from the Medicine Bow River drainage area.

of the 44 anomalous sediment samples, 25 could be associated with four areas of known uranium occurrence: 14, with the Great Divide Basin; 5, with the Poison Basin District; 4, with the Saratoga area; and 2, with the Miller Hill area. Other clusters of anomalous sediment samples indicated areas where the uranium content of sediments is significantly higher than background and where no uranium mineral occurrences are known: a cluster of three anomalous samples along the Encampment River and Miner Creek in the Sierra Madre Mountains; three along the Mullen Creek-Nash Fork shear zone in the Medicine Bo: Mountains; two along Gramm Creek in the Medicine Bow Mountains; and three in the Medicine Bow River drainage area.

With the water and sediment samples taken during this reconnaissance, and with the limited statistical analysis used in this report, four of the five major known uranium occurrence areas in the quadrangle could be identified. The one exception is the Ketchum Buttes area, which is similar in topography, geology, and climate to both the Miller Hill and Saratoga areas. Not only are there no anomalous samples which can be associated with the Ketchum Buttes area, there are no samples in the concentration interval directly below the anomaly threshoid which can be associated with this area. However, careful examination of the water data reveals a hint of elevated uranium concentrations in samples from the Ketchum Buttes area. Since there is very little information in the open literature on the remaining 13 uranium occurrence areas, most are probably minor, both in areal extent and uranium content, and probably would not be confirmed by this type of reconnaissance.

Based on the correlation of the uranium content of samples taken from the Rawlins quadrangle during this study with the known major uranium occurrences, geology, and topography, it is concluded that the data presented in Appendixes $B$ and $C$ are valid. Furthermore, the sampling density used in this study appears to be adequate for identifying the major occurrences in this part of the country. One of the areas examined that, based on data in this report, possibly warrants further investigation is the Medicine Bow River drainage area in the northeastern portion of the quadrangle. If such a study 
i.s made, geochemical emphasis on ground water sampies (wells and spriags) and stream waters, in addition to geological and geophysical invesigitions, is recommended. The predominantly negative results obtained from sediments in ìis particular area diring this study suggest further sedinent sampling night be of little use.

The statistical treatment of the uranium jatz in this report i.s limited and not intended to examine them in depth. Rather, it is intended to locate and delineate those few percent of the water and sediment samples (the actual percentage is arbitrarily chosen) that have the highest uracium concentration; in their respective total populations. In fact, each total popidation may contain several individual popdlations !perhaps corresponding to exposures of the various rock types, geomorphic proviaces, topography, sample source type, ete.), each of wich could have its own "anomaly threshold." To allow $a$ mone complete analysis of the uranium jatz, a magnetic tape of the data in Appendixes 3 and $C$ can be obtained from the National Technical Information Service, Oak Ridge National Laboratory, Oak Ridge, Tennessee, or the data i 1 the Appendixes may be used.

\section{ACKNONLEDGMENTS}

The autinors gratefully asknowledge the support of the following :ASL individuals and groups without whose help this ineport would not have been possible: Glenn R. Waterbury, William H. Ashləy, and Arthur L. Henigksinan of the Analytical Chemistry Group, C:1B-1, who performed the fluorometria analyses of the water samples; Merle E. Bunker, Michael \%. Minor, Halter K. Hensley, James S. Bergauer, and Dorothy $M$. Hatcher of the Research Reactor Experiments Group, P-2, who performed the delayed-neutron counting of the sediment and soine water samples; and Carlotta MeInteer, Jesse Cheadle III, Gayle J. Thomas, and June Pirtle of the Energy Systems and Statistias Group, Q-12, who were responsinie for data storage, statistical treatments, and grapic plots. Special thanks go to the following menbers of the Geocheni.cel Applications Group, G-5: Patricia R. O'Rourke and Judy A. Wilkinson for typing and editing, the text; John $\mathbf{E}$. Tubb, Mary Ann Olson, and Anthony T. Garcia for preparing the figures and plates in the report; Robert R. Sharp, Jr., Spencer S. Shannon, .Jr., David E. Broxton, Paul i. Aamodt, and Stephen L. Bolivar for their critical review and helpful jiscussions on all aspects of the report; and Sandra C. Feliman, for her help in reviewing the geologia and uranium occurrence li.terature relevant to the study area. Finally, sincere appreciation goes to the landowners and the US Forest Service who provided access to their lands for the purpose of sampling. Without their kind cooperation, tisis reconnaissance could not have been conducted. 


\section{REFERENCES}

Barlow, J. A., Jr. (Ed.), 1969, Symprsium on Tertiary Rocks of Wyoming, Wyoming Geol. Assn., 21si Field Conf. Guidebook, Casper, WY, p. 7 .

Becker, C. F., and Alyea, J. D., 1954a, Temperature probabilities in Wyoming, Univ. of Wyoming Agricultural Experimental Station Bull. 415, Laramie, WY, $157 \mathrm{p}$.

Becker, C. F., 1964b, Precipitation probabilities in Wyoming, Univ. of Wyoming Agricultural Experimental Station Bull. 416, Laranie, WY, 97 p.

3lackstone, D. L., Jr., 1971, Traveler's guide to the geology of Wyomin:s, Nyoming Geol. Survey Bull. 55, 2nd Ed., Laramie, WY, 90 p.

Blackstorie, D. L., Jr., 1975, Late Cretaceous and Cenozois history of Laramie Basin region, southeast Wyoming, Geol. Soz. America Memoir 144, Boגlder, Co, pp. 249-279.

Elevatorski, E. A., (Comp.), 1976, Uranium guidebook Sor Wyoming, MINOBRAS, Dana Point, CA, $88 \mathrm{p}$.

Finch, W. T., 1967, Geology of epigenetic uranium deposits in sandstone in the United States, US Geol. Survey Prof. Paper 538, Wasinington, DC, 121 p.

Finnell, T. L., and Parrish, I. S., 1958, Uranium deposits and principal one-bearing formations of the central Cordilleran foreland region, LS Geol. Survey Mineral Tnvest. Map MF 120, 1:750 000 scale, Washington, DC.

Fix, P. F., 1956, Hydrogeochemical exploration for uranium, in Contributions to the Geology of Uranium and Thorium by the United States Geological Survey and Atomic Energy Commission for the United Nations International. Conference on Peaceful Jses of Atomic Energy, Geneva, Switzerland, 1955, US Geol. Survey Prof. Paper 300, Nashington, DC, pp. 667-571.

Graff, P. J., and Houston, R. S., 1977, Radioactive conglomerate in Proterozoic (Precambrian X) metasedimentary rocks of the Sierra Madre, Wyoming, US Geol. Survey Open File Report 77-830, Washington, DC, 7 p.

Houston, R. S., 1961, The 3ig Creek pegmatite area, Carbon County, Wyoning, Geol. Survey of Wyoming Prelim. Report No. 1, Laramie, WY, 11 p.

Houston, R. S., 1969, Aspects of the geologic history of Wyoming related to the formation of uranium deposits, Contributions to Geology, v. 8 (2), pt. 1, Univ. of Wyoming, Laramie, WY, pp. 67-79.

Houston, R. S., 1971, Regional tectonies of the Precambrian rocks of the Wyoning province and its relationship to Laramide structure, in: Proceedings of a Symposium on Wyoming Tectonics and Their Economic Significance, Wyoming Geol. Assn., 23rd Field Conf. Guidebook, Casper, WY, pp. 19-?7. 
Houston, R. S., and others, 1968, A regional study of rociss of Precambrian age in that part of the Medicine Bow Mountains lying in southeastern Wyoming-with a chapter on the relationship between Precambrian and Laramide structure, Geol. Survey of Wyoning Memoir No. 1, Laramie, HY, 157 D.

Hunt, C. B., 1974, Natural Regions of the Jnited States and Canada, W. H. Freeman and $\mathrm{Co}_{0}$, San Francisco, CA, pp. 373-423.

Intrasearch, 1977, Geology of the Rawlins quadrangle, map (1:250 000 scale) prepared for Bendix Field Eng. Corp. according to BFEC Specification 1125, Grand Junction, co.

Love, J. D., 1961, Splis Rook formation (Miocene) and Moonstone formation (Pliocene) in central Wyoming, US Geol. Survey Bull. 1121-T, Washington, DC, $37 \mathrm{p}$.

Lowry, M. E., Rucker, S. J., IV, and Wahl, K. I., 1973, Water resources of the Laramie, Shirley, Hanna Basins and zdjacent areas, Southeastern Wyoning, US Geol. Survey Hydrologia Invest. Atlas HA-471, Washington, DC.

Magleby, D. N., and Mallory, N. S., 1954, Airborne radiometric survey of the Browns Park Eormation, Carion County, Wyoming, US AEC Report No. RME-1055 (Rev.), Grand Junction, CO, $20 \mathrm{p}$.

Masursky, H., 1962, Uranium-bearing onal in the eastern part of the Red Desert area, Wyoming, US Geol. Survey Bull. 1099-B, Washington, DC, 152 p.

Masursky, H., and Pipiringos, G. N., 1959, Uranium-bearing coal in the Red Desert area, Sweetwater County, Wyoning, in: Uranium in Coal in the Western United States, US Geol. Survey Bull. 1055, Washington, DC, pp. 181-215.

National Oceanic and Atmospheric Administration, 1976, Climatological Data, Wyoming, US Dept. of Commerce, NOAA, v. 85 (Nos. 5-7 and 12), Ashevill.e, NC.

National Dceanic and Atmospheric Administration, 1977, Climatological Data, Wyoming, US Dept. of Commerce, NOAA, v. 86 (Nos. 1-5), Asheville, NC.

Ormond, A., 1957, Prelininary report on the geology of uranium deposits in the Browns Park formation in Moffat County, Colorado, and Carbon County, Wyoming, US AEC Report No. TM-D-1-18, Grand Junction, CO, 30 p.

Shannon, S. S., Jr., and Ruzyciki, J., 1957, An airborne radiometric survey of parts of Albany and Carbon Counties, Wyoning, US AEC Open File Tech. Memo. TM-1-D-15, Grand Junction, CO, $30 \mathrm{p}$.

Sharp, R. R., Jr., 1977, The LASL approach to uranium geochemical reconnaissance, in Symposium on Hydrogeochemical and Stream-Sediment Reconnaissance for Uranium in the United States, US DOE Report. GJSX-77(77), Grand Junction, CO, pp. 353-373.

State of Wyoming, 1975, Wyoming Data Handbook, Wyoming Dept. of Admin. and Fiscal Control, Cheyenne, WY, pp. 115-116. 
Stephens, J. G., and Bergin, M. J., 1959, Reconna issance investigation of uranium occurrences in the Saratoga area, Carbon County, Nyoming, US Geol. Survey Bull. 1045-M, Washington, XC, pp. 321-338.

Thomas, H. D., 1949, The geological history and geological structure of Wyoming, Geol. Survey of Wyoming Bu1.l. 42, Laramie, WY, 28 p.

US Geologica? Survey, 1968, Rawlins, Wyoning; Colorado, Topograpinio Map NK13-7, 1:250 000 scale, Denver, Co.

Vine, J. D., and Prichard, G. E., 1959, Geology and uranium occurrences i. the Milier Hill area, Carbon County, Wyoning, US Gesl. Survey Bull. 1074-F, Washington, DC, pp. 201-238.

Welder, I. E., and Mefreevy, L. J., 1965, Ground water reconnaissance of the Great Divide and Washakie basins and some adjacent areas, southwestern Wyoming, US Geol. Survey Hydrolopic Invest. Atlas HA-219, Wasinington, DC.

Wilson, W. H., 1950, Radioactive mineral deposits of Wyoming, Geol. Survey of Wyoming Report of ravest. No. 7, Laramie, wY, $41 \mathrm{p}$.

Wyant, D. G., Sharp, W. N., and Sheridan, D. M., 1956, Reconnaissance study of uranium Jeposits in the Red Desert, Swoetwater County, Wyoming, US Geol. Survey Bull. 1030-I, Washington, DC, pp. 237-308. 
APPENDIX A

SUMMARY OF STANDARD LASL HSSR FIELD AND ANALYTICAL PROCEDURES 


\section{APPENDIX A}

SIMMAARY OF STANDARD LASL HSSR FIELD AND ANALYTICAL PROCEDURES

\section{FIELD PROCEDURES}

Wi: er Sampling

Water samples are taken directly from the sounce whenever possible, iitered through a $0.45-\mu$ membrane filter into one each, prewashed and sealed, 4i-ml reactor "rabbit" and 25-ml vial (both polyethylene), and both are then anidified to $a \mathrm{pH}$ of $\leq l$ with $8 \mathrm{~N}$, reagent-grade, HNO 3 . All sample containers are doubly labeled with preprinted, adhesive labels carrying tine sam sample location number prepriated on the field data form. Springs are sampled as npar to their point of energence as possible; stream waters are taken fron fast-flowing current away from the bank; ponds (including small lakes and reservoirs) are sampled froin just below the surface, away from the bank; and well waters are talcen near the hellhead if trie well is pumping or irom a holding tank if not.

Sediment Sampling (Wet or Dry)

Enough fine-grained, organic-rich, water-transported sediment, to yield a composite 3ample of $25 \mathrm{~g}$ after processing (as indicated below) is taren from beneath the water level (where water exists) at three closely adjacent spots at each location. This is done with a polyethylene scoon, after the water sample (if any) is taken. The sediment is put into a new, elean, and originally sealed, rip-top polyethylene bag and properly double-labeled for delivery (with the field data form) to the contractor's drying facility. After drying at $\leq 100^{\circ} \mathrm{C}$, each sample is sieved through stainless steel sieves to -100 mesh. The -100 mesh fraction i.s put into a prewashed, 25-ml polyethylene vial, appropriately double-labeled (using labels from the data (orm), and sealed for shipment to the IAASL.

\section{Field Measurements}

The ais temperature, taken in the shade at the time of sampling, is recorded to the nearest, whole degree Celsius. The water temperature is measured in the source water and recorded to the nearest one-tenth degree Celsius. All temperature measurements are made with quality, procalibrated thermometers. The $\mathrm{pH}$ of the source water is measured with a calibrated, portable $\mathrm{pH}$ meter or multi-range $\mathrm{pH}$ paper, and recorded to the nearost onetentin of a pH unit. The specific conductance ( $\mathrm{pmho/cm}$ ) of the source water is measured with a calibrated, temperature compensated $\left(25^{\circ} \mathrm{C}\right.$ ) portable meter after the aitached sample cup has first been rinsed three times ia the source water. The scintillometer readings, taken on a flat, dry spot within a few meters of the sample location, are measured with a portable scintillometer. Two readings are recorded, the first with a radiation shield in place (blocking out ground radiation), and the second with the shield removed. The readings (in nounts/s) are converted by computer (using calibration factors obtained from testing of the scintillometers on a calibration block) to give the equivalent uranium (eU) value set forth in the data listing. 
Field Observations

These napresent the bost sihjestive judgnent or the field sampler on location, ant include very generil jescriptions or the loozl bedrock, sefinent, water, vegetation, topraia, weztier, possible onntaninants, and water well 1 configurztion, ir applicable.

Sample Lccation Verification

Fach contractor is suppiled field maps with the desined sample types and locations symbolical?y premarked at the LASL. The map.3 are normally USAs

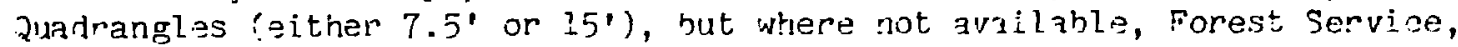
State Highiay, or uther reasonahly detailed maps are provided. As each location is sampled, a unique sample location number, preprizted on transparent arjesive labals provided with the identically nimbered field data corms, is pasted over the precisely marked site on the fielf nap. The latitude and longitude of each location is computed by the samp!ing contractor. Every lonation is latur checked (and corrected if necessary) at the LASL by overiaying computar-produced location plotis on the field maps used. The latitudes ant/or longitudes are corrected if the ovorlay locations are displaced by more than $100 \mathrm{~m}$ from the locations markod on the rield maps. When a desired location cannot be samplod as specified, an alternate sampla type or location as near as possible to the original on? is piciced, and the ne's sampie type and/or location is/are marked on the fielt map and properly labeled as above.

\section{IT. ANALYTICAL PROCEDIJRES}

Water Samples Analyzed for Uranium by Fluorometry

In a controlled laboratory envi conment, $\mathrm{a} \mathrm{NaF}$ (98\%)-Lif (2\%) flux pell ot, is prepared and placed on a platinum dish. The 25-ml water vial. is vigorously shaken and $a 0.20-\mathrm{ml}$ al iquot of water is withdrawn and dropped onto $a$ Plux pellet, then evaporated under a heat lamp. The sample flux is then heated until fused. After it cools, it is excited with ultra-violet radiation in the fluorometer, and the measured fluorescence is read, recorded, and put through z computer routine using standards and blanks run at the same time to obtain the uranium concentration. All fluorometer analyses are done in duplicate and the average value for the two splits of a sample is reported herein. If an analysis inficates that the total uranium content of a given split is less than the lower detection limit of the method, 0.20 parts per billion (ppb) uranium, an arbitrary value of 0.10 ppb is assigned to that split and the 0.10 $\mathrm{ppb}$ is averaged with the duplicate split to obtain the reported value. $\mathrm{tf}$ one split has a total uranium content less than the lower detection limit and one split is at or just above said limit, uranium contents between 0.10 and 0.20 ppb can result; if both splits have uranium contents below the lower detection limit, the reported value for the sample will be $0.10 \mathrm{ppb}$. Water sainples which either have uranium concentrations in excess of 10 ppo or have elemental interference are generally reanalyzed using the delayed-noutron counting (DNC) technique described below. Analytical precision at the lowen linit of deteation is $230 \%$; however, it improves to $210 \%$ one order of magnitude above the lowen limit.

\section{Water Samples Analyzed for Uranium by DNC}

Waters with $>10$ pp uranium and those containing high enough concentrations of certain elements to interfere with fluorometric analysis are assayed 
using DNC. The exteriors of the field-returned, 41-ml rabbits containing water samples are thoroughly cleaned before analysis. Samples received in 25-ml vials (used exclusively in some of the early work) are transferred to clean, labeled, 4l-ml rabits before being analyzed. Each water sample is weighed, and its weight !less that of the rabbit) and location number are recorded. The rabbits are then loaded into a 25-sample transfer slip. The reactor pneumatic transfer system and background radiation lovels are checked, and the system is caliorated using four standards. The transfer elip is installed on the pneumatic feed line, and the count control i.s set (typically, a 50-s irradiation, a 30-s delay, and a 50-s count are sised, but tis can bo changed to accommodate abnormally high or low uranilum concentrations). The samples are cyoled through the system and the uranium concentration i:3 aldtomatically measured, computed in ppb, and entered into the data base. Statistical treatments of uranium concentrations obtained on tine same suites of samples both by fluorometry and DNS have shown that there is no sijnificant difference between results of tine two analytical methods as used at the LASL. This analytica? omparability is rechecked periodically. Uranium concentration for those water samples assayed by DNC are denoted by asterisks foliowing the uraniurn concentrations in Appendix $B$.

Uranium Analysis ô Sediment Samples

All sediment samples are analyzed for total uranium by DNC. 4 split of each sample (dried and sieved as described) is transferred to $a$ alsan $4-m l$ rabbit, weigined (less the tare), and recorded along with the appropriate location number. The readied rabbits are loaded into a 50-sample transfer cli.p. The reactor pneumatic transfer system and background radiation leyels are cinecked, and the system is calibrated as above. The transfer elip is installed and the count control is set (typically, a 20-s irradiation, a 1n-s delay, and a 20-s count are used). The samples are cycled through tine sysiem and the uranium concentration is automatically measured, computed in parts per million (ppm), and entered into the data base. The lowen linit of detection for uranium in sediment analyzed by the DNC method is 0.5 ppb (not ppm); thi.s is so low that it has never been reached while analyzing a natural sediment, sample. The precision of the DNC method i.s $4 \%$ or better for all znalyses. 
APPENDIX B

LISPINGS OF FIELD DATA AND URANIUM CONCENTRATIONS

FOR WATER SAMPLES

(See Appendix D for Code to Listings) 


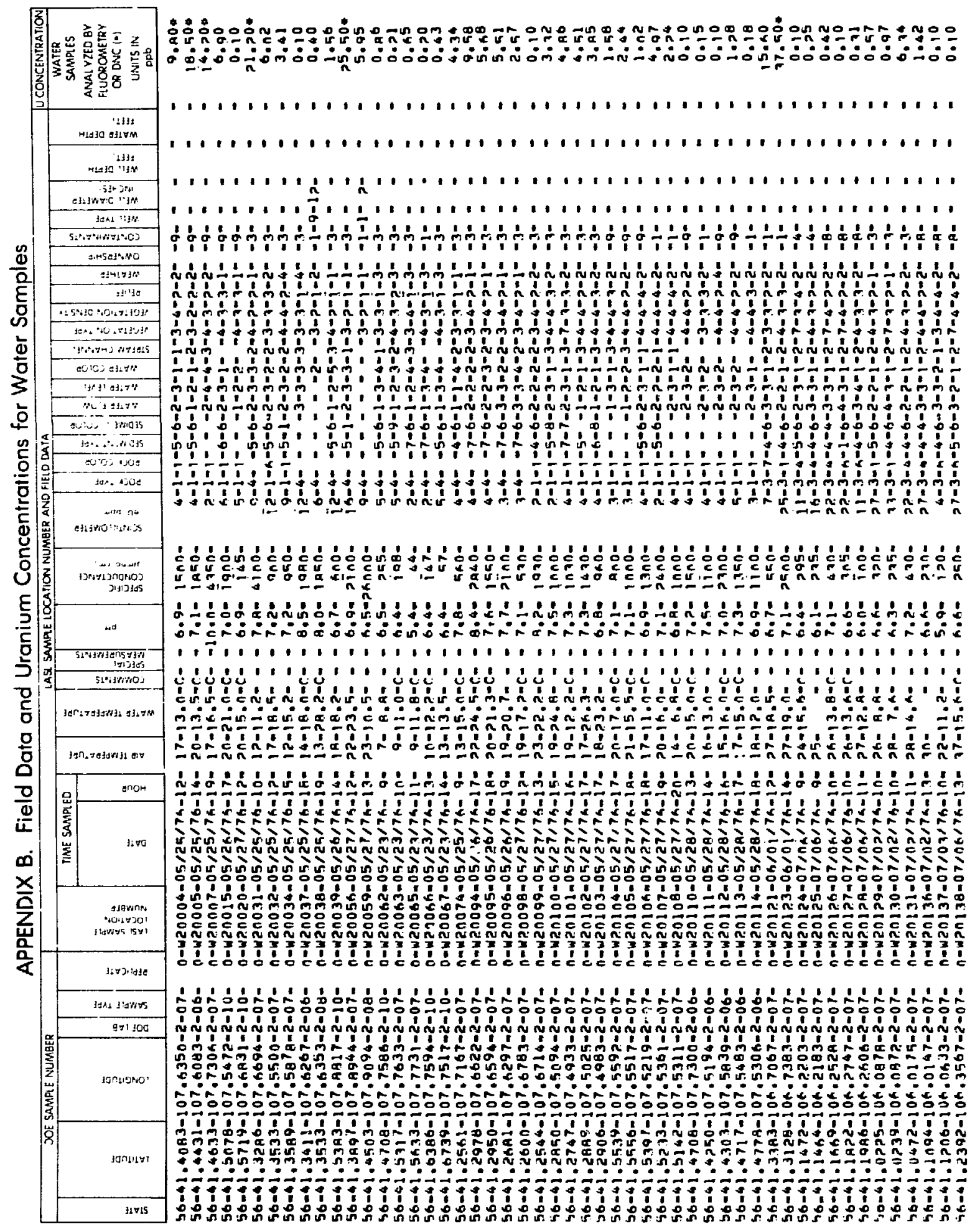




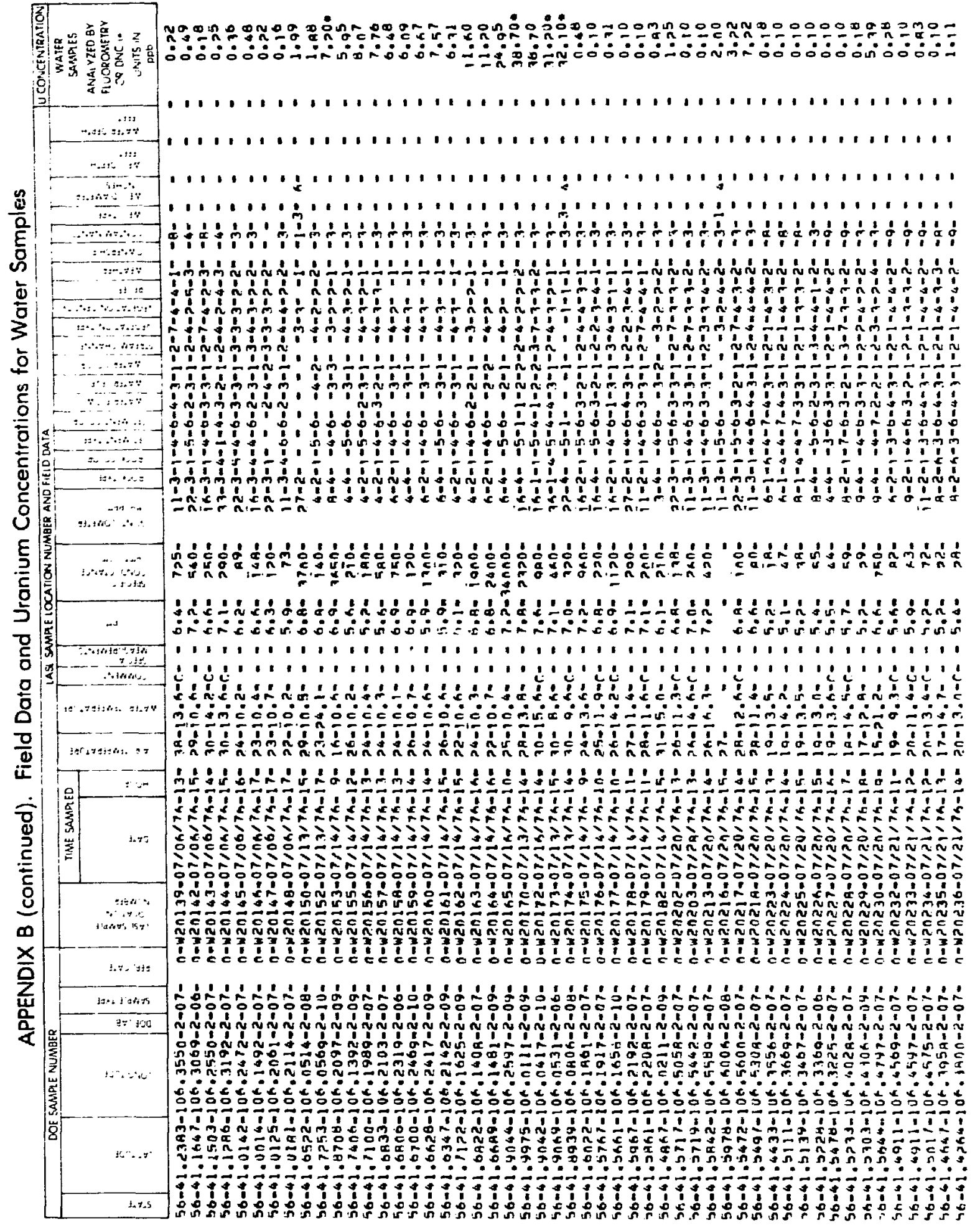




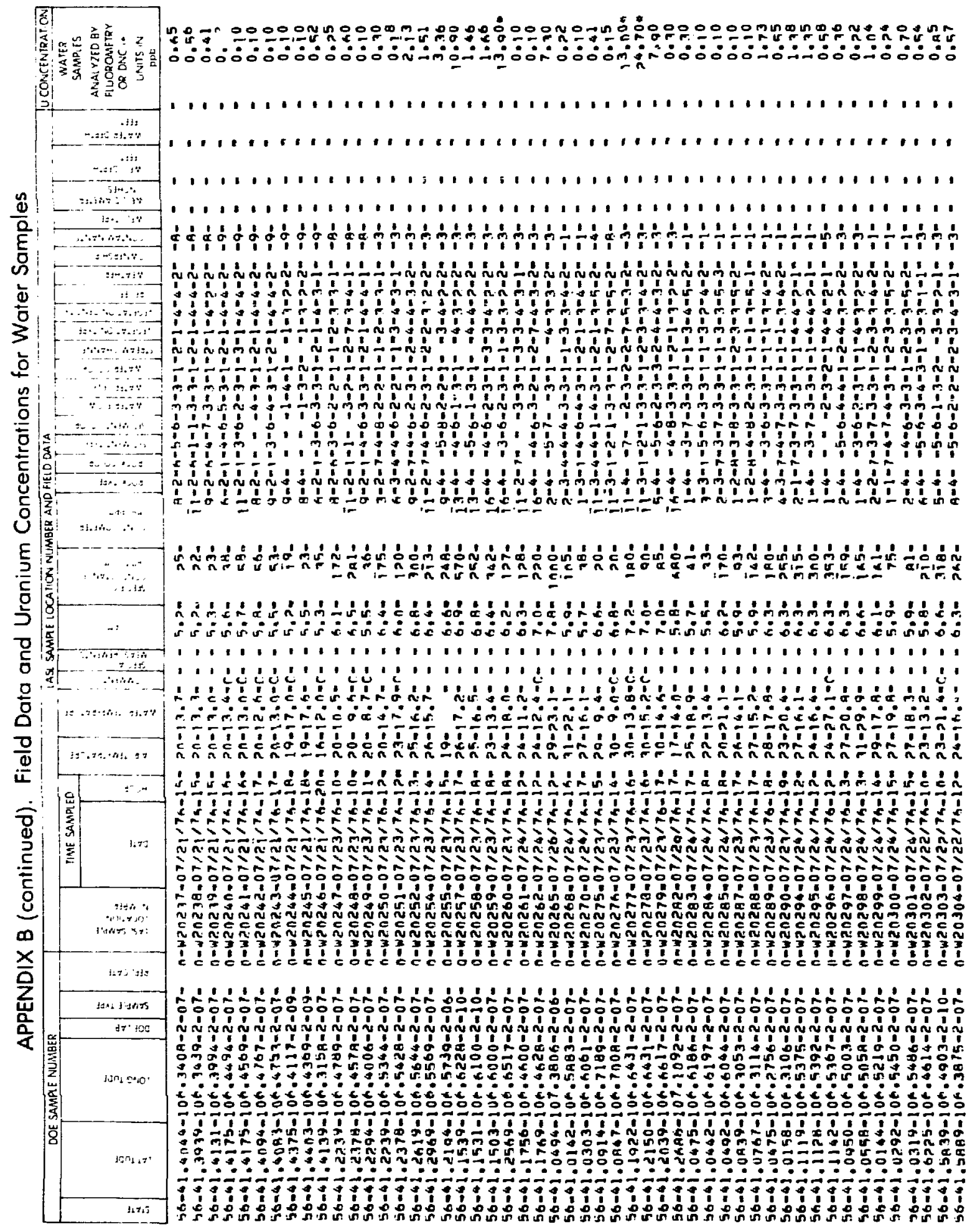




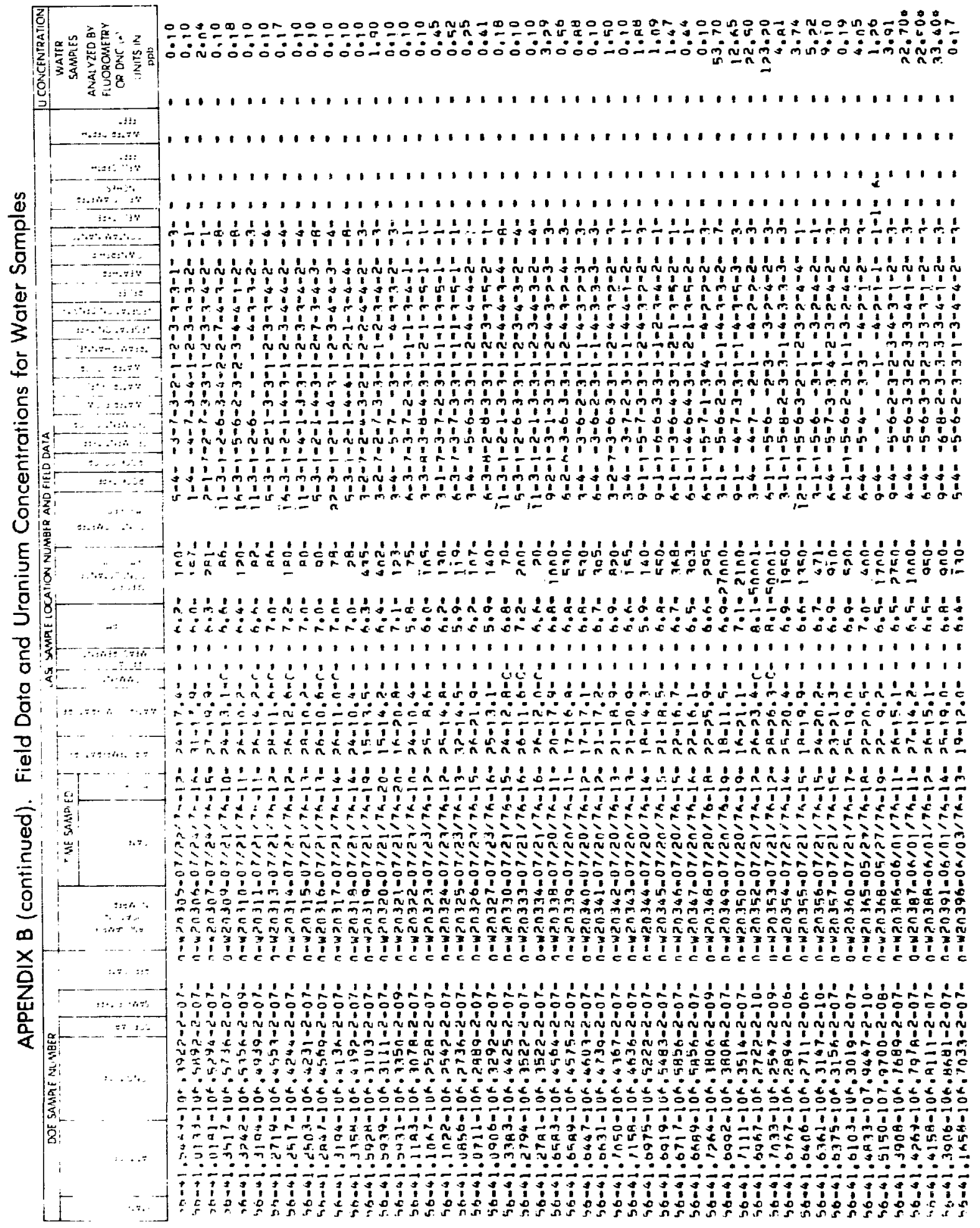




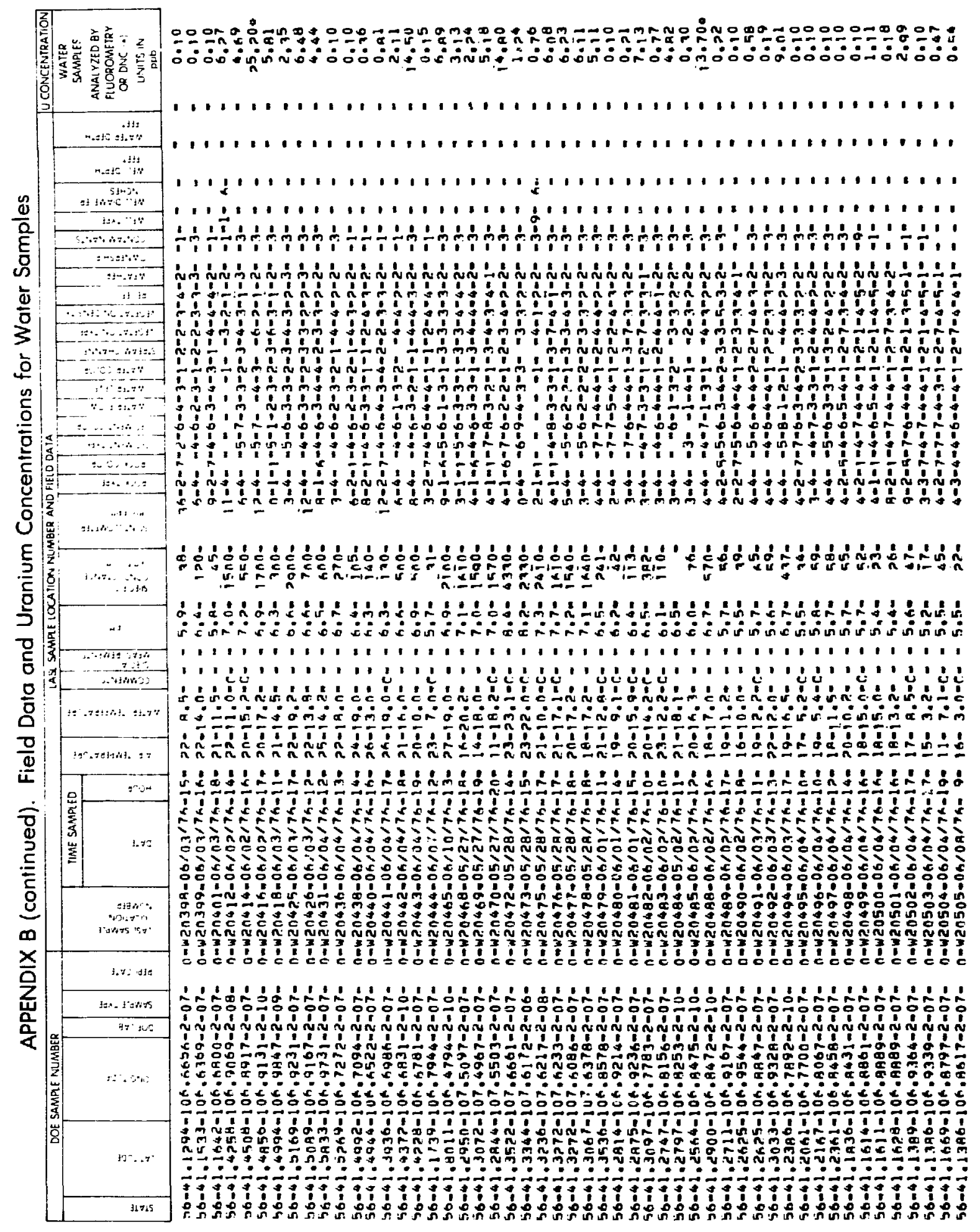


APPENDIX B (continued). Field Data and Uranium Concentrations for Water Samples

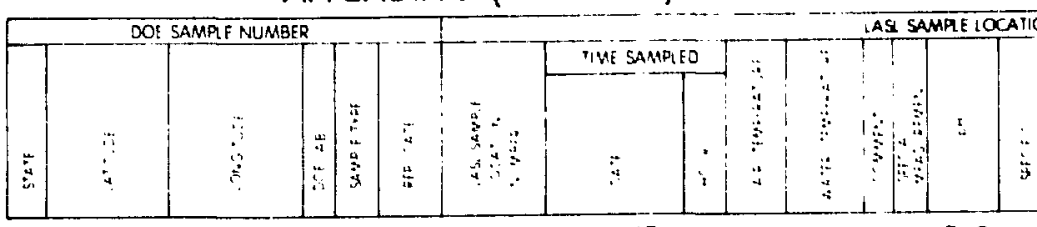

$36-41.14 A 3-10 \% \cdot A 30 B-2-07-$ $56-41.1403-104.825 A-2=07-$ $56-41.1294-104,7989-2-07-$ $56-41.1267-104.7806-2-07-$ $56-41.7069-107,695 A-2-10-$ 56-41.695t-10A.9456-2-1056-4 - $8103-106.6650-2-09-$ $56-41 \cdot B 203-104 \cdot 4531-2-07-$ $56-41.7678-104.8475-2-10=$ $56-41.7000-104.8661-2-07=$ $56-41$. $6844-10 \%$. $4669-2-07-$ $26-41,8903-107,3444-2-10-$ $56-41,1978-106 \cdot 4683-2=07-$ $56-41.4944-107-4639-2-10-$ $56-41.1541-106.4581-2-07=$ 56-41.154 - $100.4581-2-07=$

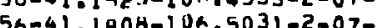
$56-41$. 56-4) $36-41.1711-104.5267-2-07=$ $36-41.1711-104.5267-2-07-$ $56-41.0442-104.3992-2-06=$
$56-41.0461-104.4261-2-07=$ $56-41.0461-106.4261-2-07-$
$56-42.2031-104.9211-2-07=$ $56-42.2041-106.9211-2-07=$ $56-41.2156-104.9253-2-07=$ $36=41.0950-107.1572-2=07=$ $36-41 \cdot 0394-107 \cdot 1264=2-07-$ $36-41.2719-107,1564-2=07$ $36-41.2719-107+1586-2=07-$ $36-41.2739-107,1597-2-07-$
$56-41.139 /-107.01064-2-07=$ $56-41,1397-107,0864-2=07=$ $36-41.1486-107.0292-2=07-$ $36-41 \cdot 1514-107 \cdot 0456-2-07-$ $56-41,1339-107,0703-2=07=$ $76-41-2742-107,258.7-2-100$
$76-41,2417-107, ? 706-2-07-$ $36-41,2417-107, ? 706-2-07=$
$56-41,2425-107,3027-2-07-$ $36-41.2403-107.3181-2-07=$ $36-41.2494-107 \cdot 3347-2-07=$ $56-41.2347-107 \cdot 3647-2-07$ $56-41$. द6म1-10? -354?-2-0 $36-41,4744-107.3525=2-07=$ $36-41.2796-107-2837-2-07$ $56-41.31 A^{4}-107.2647-2-07=$ $76-41.3797-107 \cdot 2492-2-07-$ $76-41.3449-107.7744-2=07$ $36-41.3481-107-277 ?-2-07-$ $56-41.3550-107-2 A 75-2-05-$ $5 A-41.352 H-107 \cdot 3544-2=07$ $n-W 20507-0 B / 0 a / 7 h-10=2 n-5.2-=-5.9-$ 年 n-W2n509-06/0877a-11- 20-h.7- = -5.7- j6n-W2n510-06/0A/76-130 34-9.2- - - B.n= OnO-W20515-06/09/74-9- ?n-18.n-C:- 7.0- 3RO-

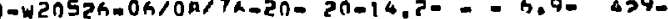
n-N20530-0h/09/7h-10-24-19.0)C- = B.h-5000ln-W20531-06/09/7h-10- 3h-19.?- - = 7.7. >740$0-W 20539.06 / 09 / 74-9.38-\quad=-$ - T.20 9An$0-W 20552-06 / 10 / 74-10037-=-=7.4=000-$ -W20560-06/10/7h-13*35- = - 7.4- 330$0-120566-06 / 12 / 7 n-13-20-13.6 n=-k .5-17 A-$ -w20574-06/10/76-14-27-19.0- - - 7.9- 1ain-

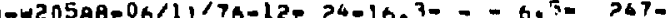

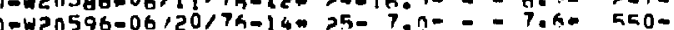

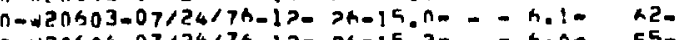
0-W20604-07/24/7A-17- PA-15:3- = - h.C. a5-

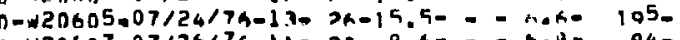
B-W20607-07/2G/7G-11- 201-A.h- - - bota-94-

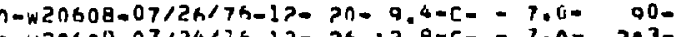

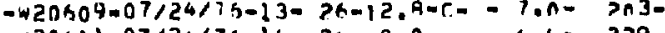

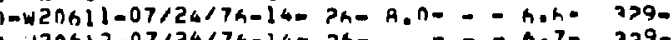

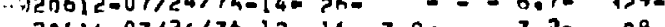

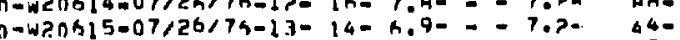
$0=W 20 B / b=07 / 2 a / 7 A-1 h=74-9.4-C=-A . A=$ A2-

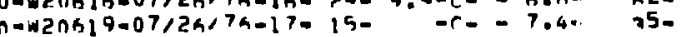

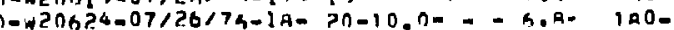

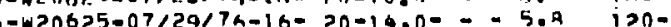
n-w20636-07/29/7a-1he Pn-13.n- - - 5.h 03-

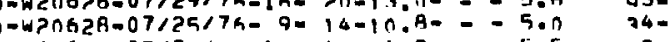
-W20629-07/2h/7h-1h=17-11.2- - - 5.5. 49-

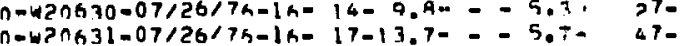

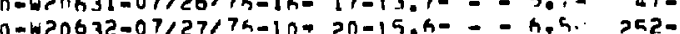

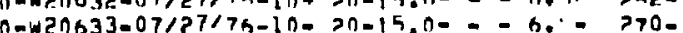

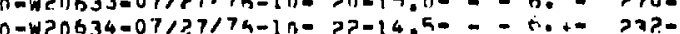
n-w2n634-07/27774-1n- ?7-14.5- $n-w 20 B 35-07 / 27 / 74-11=23-16.3=-E+1.6-342-$

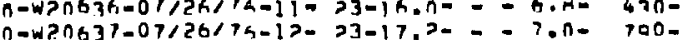

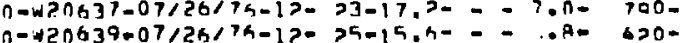

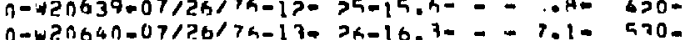

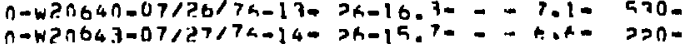

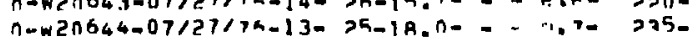
n-W20646-07/27/7h-16- 26-1R.4- = 104- 2nn-

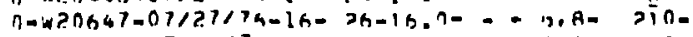
n-w2064A-07/27/7h-1h- 26-1h.0= - K.4- $270-$ $n-w 20649-07 / 21 / 74-14-26-13.2-=5.9-2 n n-$

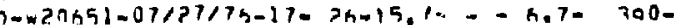

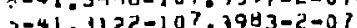

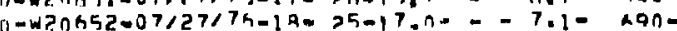

$5-2-4-4-6-5-4-i-2-3-4-4-1--1--$ $7-2-7-4-6-4-4-1-2-3-4-4-1--1-=$ $7-3-5-4-6-5-4-1-2-1-4-5-1--3-=$ $5-2-4-4-7-4-3-1-2-2-3-5-1-3-3=$ $4-4-1-7-1-2-4-1-1-7-3-3-1--1=-$ $5-4--5-6-1-2-1--4-2-1-4--3-$
$7-4--5-8-1-2-1--4-3->-1-3-$ 7-4- $-5-8-1-2-1--4-3-3-1--3-=$ $7-4--5-6-1-2-1-1-4-7-1-1--3-$
$4-1-4-5-6-1-2-3--4-4-2-1-=3-$ $4-1-x-5-6-1-2-3--4-4-2-1--3-=$
$3-4--5-6-4-4-3-2-4-4-7-1=-3-=$ $3-4--5-6-4-4-3-2-4-4-7-1=-3-$
$4-4--5-6-4-3-3-2-4-2-3-1=-3-$ A-2-7-5-6-1-4-2-3-4-4-2-3-3-3-= $5-1-1-h-6-2-2-1-3-3-3-3-2-3-7-=$ 5-4- -6-6-1-3-3- $-4-7-1-2=-3-=$ $4-4--5-6-1-2-1-3-4-3->-1--3-=$ 16-2-1-4-8-3-3-1-2-3-7-3-2- -B$1-2-1=--4-3-1-2-3-3-4-2=-R-$

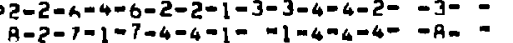
$11-2-7-1-7-4-4-1-2-7-5-4-4--R-=$ $5-2-n-4-6-3-3-1-2-7-6-3-2--3-=$ i $1-2-7-6-6-3-3-1-3-4-3-4-2--\beta-=$ 1 $1-2-7-4-7-4-4-1-2-1-4-4-4--B=-$ 1 $1-2-1-1-7-3-4-1-2-1-4-4-4--2-=$

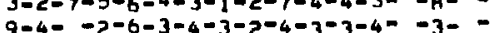

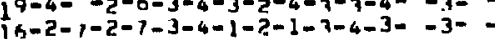
17-2-7-4-6-3-2-1-2-1-4-4-2- -810-2-7-3-6-2-3-1-3-1-4-4-2- - $A-$ $1-2-7-4-6-4-4-1-2-1-7-7-2=-8-$
$3-2-4-3-6-4-3-1-2-1-4=4-2-=8-$ $3-2-4-3-6-4-3-1-2-1-4=4-2-=8-$
$3-2-7-3-6-3-3-1-2-1-4-4-3-3-$

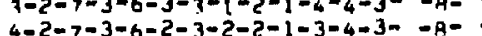
$4-2-7-3-6-2-3-2-5-1-3-4=3-4-8=$
$4-4--5-6-2-3-1-3-4-3-3-1--3-$ $4-4--5-6-2-2-1-3-4-7-3-1--3-$
$4-4--5-6-2-2-2-3-3-3-3-1--3-=$ $4-4--5-6-2-2-2-3-3-3+7-1--3=$
$7-4--5-6-2-3-1-2-7-7-1-1--3-$ $4-4--5-6-2-2-1-3-3-3-3-1--3-=$ $4-4--5-6-2-2-1-3-3-3-3-1=-3-$
$7-4-5-2-3-1-3-3-3-3-1-3-$ 7-1-n-5-6-2-2-1-3-3-3-7-1--3- = $7-1-h-5-6-2-2-1-3-3-4-3+1--3-=$
$4-1-6-4=6-3-2-1-2-3-4-3-2--3-=$ $4-1-6-4-6-3-2-1-2-3-4-3-2-=3-$
$5-1-4=4-6-3-3-1-2-3-3-3-5-3-$ 4-2-4-5-6-2-2-1-3-4-4-7-2- -3- = $10-4--4-6-2-2-1-2-3-3-3-2--3-=$ $6-1-1-4-6-3-3-1-2-3-3-2-2--3-=$
$8-1-1-4-6-3-3-1-2-3-3-2-2--3-$ $i>-1-1-3-6-3-3-1-3-3-3-3-2--3-=$

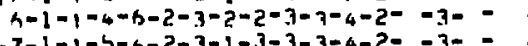
$-7-1-1-5-6-2-3-1-3-3-3-4-2--3-=$
$7-1-1-5-6-2-3-1-3-3-3-7-2--3-$

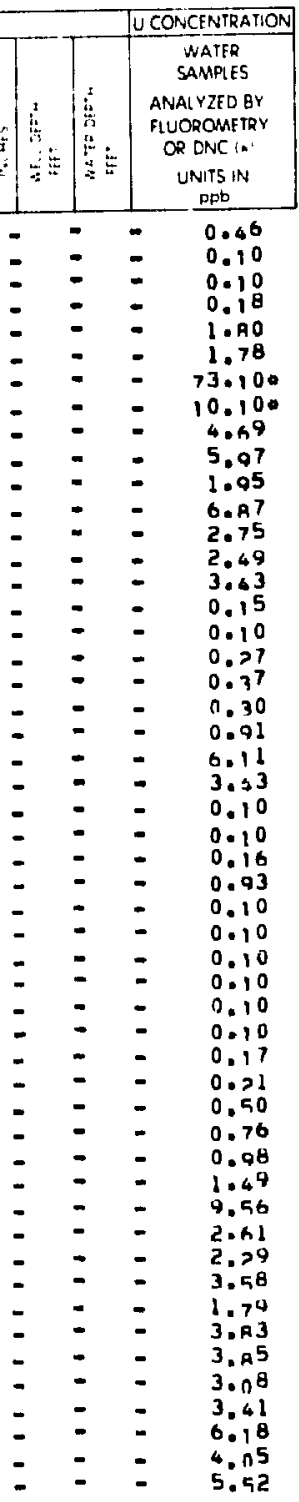




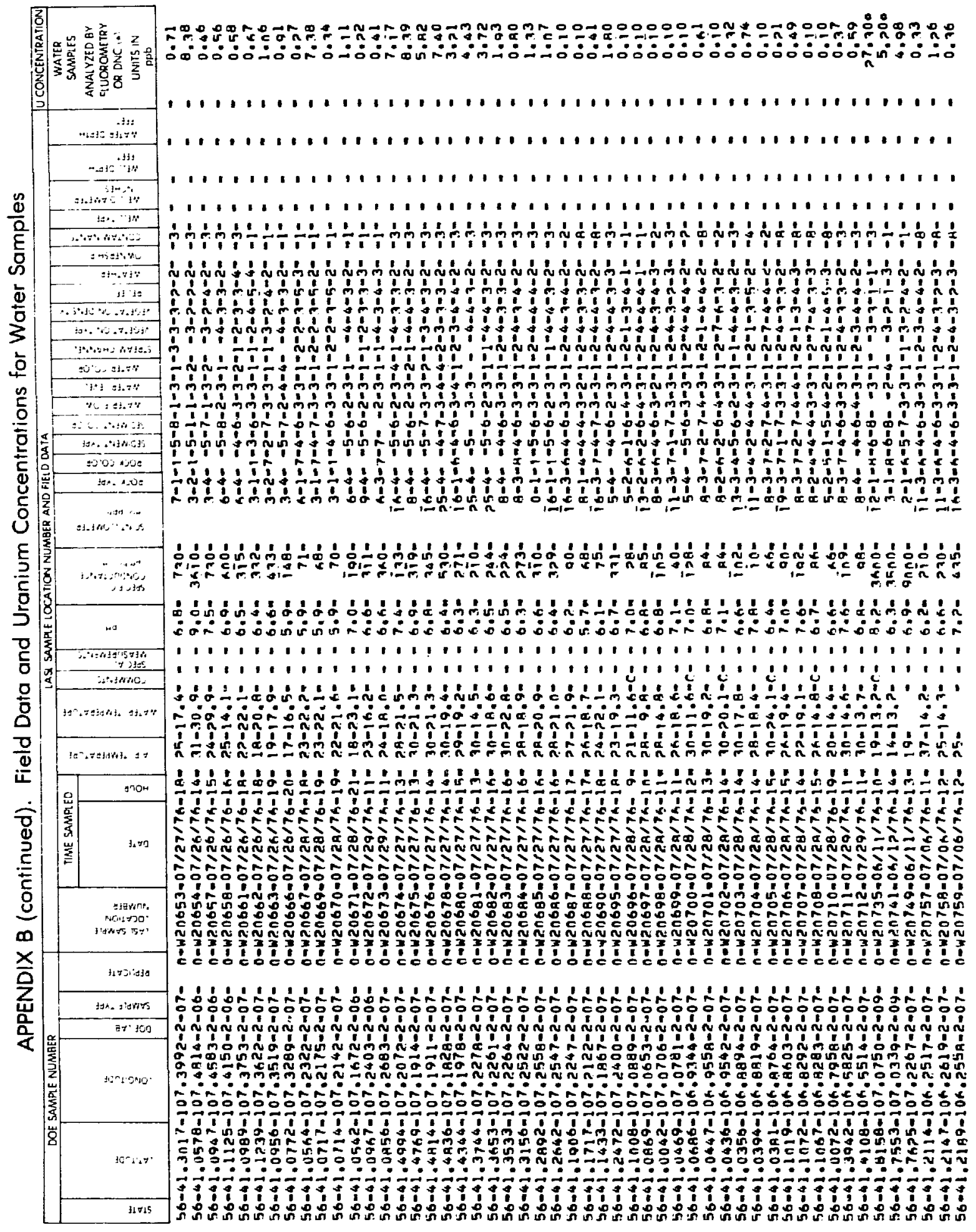


APPENDIX B (continued). Field Data and Uranium Concentrations for Water Samples

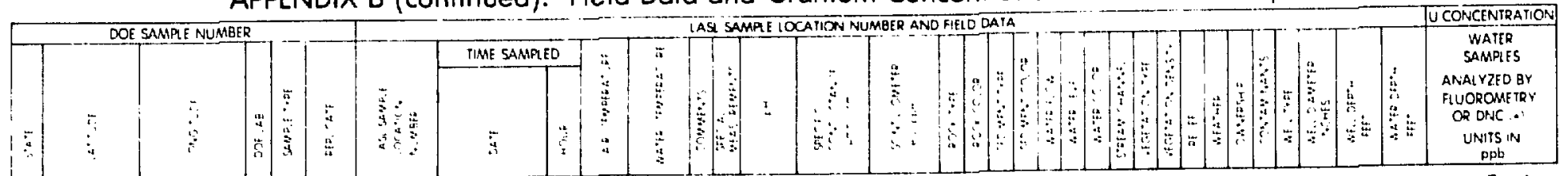

$06-41-2314-104-0314-2-07$

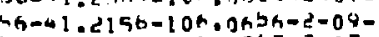
66-61. 2 ती Sh- $41.15 k 9=10 \%$ - $155 A-2-07$ $36-41.] 546-106,0464-c=07=$ $36-41+132 ?-104 \cdot 11.353-2-07-$ $36-41.1336-10 h, 0331-2=07$ $66-41.1256-10 \% .1724-2-07-$ $S_{6}=41.1276-10 \mathrm{~K}, 142 \mathrm{C}-2=07$

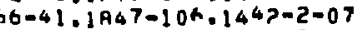
3h-41.1594-104.1983-2-07 $36-41$ - $2156-10 \mathrm{r} \cdot 12^{44}-2-07$ $36-41.234 /-104-16+9-2-07=$ $36=41.2336-104.1617-2-07$ $56-41.1208-106.0667-2-07$ $66-41.1346-104.0653-2=01$ b6-41.1161-106.1067-2-0766-4) $1153-106.105 h-2-07$ $56-41.1136-104 \cdot 0.789-2=07=$ $56-41.0206-106.0439-2-07$ $46-41.0599-10 \%$. 11 39-2-07$56-41$. UAn0-10h.1361-2-0756-41. 1 1097-10h. 1569-2-07$56-41.1228-10 \mathrm{H}-1717-2-07=$ $56-41,1161=10 \%+2396-2-07=$ SO-41.1153-10h.24 72-2-07. 56-41. 1 >? $8-1$ OR, ?417-2-07$56-41 .<614-10 \%-1153-2-07-$ $56-41,3311-10 \% .0339-2-06-$ $5 A-41,3528-104 \cdot ? 27 A-2-07=$ $46-41,5 ? 19-100,1767-2-07$ $56-41,5>00-106,1700-2-07-$ $56-41$ 3950-10h $1389-2-07-$ $50-41.23 A 1-106,1944-2-07$

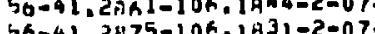
56-41.2475-10 -1म $1-2-07$ $56=41.2917-104,3303-2=07$ $56-41.3376-106,1633-2-07-$ $56-41,3.394-104.1696-2-07-$ $56-41.4594-104.2292-2-07-$ $56-41$. Y46 $1-10 \mathrm{H}$. $170 \mathrm{~A}=\mathrm{C}=07$ $56-41.4867-106-2067-2-06$ $56-41.5411-104.1239-2-07$ $56-41.4514-10 \mathrm{n}$. $2109-2=07$ $56-41.42 h 9=10 h .1853-2-07$ $36-41.42 h 1-10 \% \cdot 1931-2-07=$ $56=41.3750-10 \%, 1906-2-07=$ $56-41.3719-104.1900-2=07$ $56-41.3358-104 . ? 583-2-07$ $56-41.3344-104,2597-2-07=$

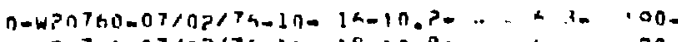

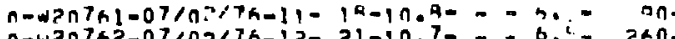
n-want6e-07/0>

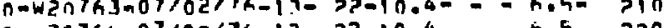
n-wentaka n-w2nths-07/02/1a-13-

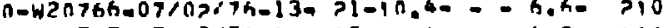
now2n767-07/03/74-10- 10-10.4- - = 6.3- 130$n-w 2 n 768-0710317 k-11=19=10.4-=-3.3=$ iann-W20769-07/03/7b-1P= 33-10.A- - 6.5- 1900-W20770-07/03/7h-13- >2-10.4- - - h.6- >30 n-w2n771-07/03/74-14-31-10.4- - hos- 7io$0-w^{2} n 772-07 / 03 \% 7 n-15 a$ 23-10.7- - - 6.5- p>0$n \rightarrow W 2 n>73-07 / 03 / 74-150$ >3-10.?- - - k.5- ?ion-w2n 774=07/0?/7A-1n- P2-11.0. - 5.7- inn n-W20775-07/03/74-11- 22-10.n- - S.A- IAnn-W2n $776.07 / 0,3 / 7 h-11-23-11.0-\infty$ - 5.9. i30 n-w2n777-07/03/74-11- 3.3-12.5- = 6.0- 1inn-W2n778-07/03/74-1 ?- $34=9.5-$ - 5.7. jan n-W2n779-07/03/74-12- 33-12.n- - 5,9- 1300 C-W2n780-07/03/74-17- 34-16.n- = 5.5. 700

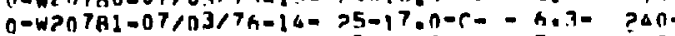
n-W2n7A2-07/03/74-14- P5-22.2- - - 5.9- izn n-W2n783-07/03/74-14= 75-17.5- - 5.7- innn-w20784-07/07/74-15- P5-17.5- - 5.7- inno n=W20785.07/03/7h-15- Ph-15.5- in - 5.5- AOC

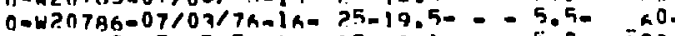
0-W20789-07/05/7n-1n-19-10.1- - - 5.5. Ta0 n=WPB792-07/05/74-1 P- >5-10.7-r. - A.9- IAnO n-W? $0796-07 / 05 / 7 h-15-14-10.5-$ - - 5.9- 70 n=w20707-07/05/74-15. 19-10.4- - 6.0- 50. $n-42 n 798-07 / 05 / 7 k-15-18-10.4-=-h \cdot n=5 n-$ D-W20799-07/05/7a-1he 24-10.5m - 5.9- 50-

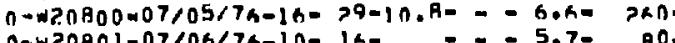
D-W20AOL1=07/06/7h-1B-1A-

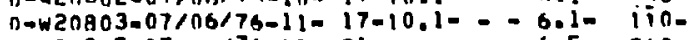

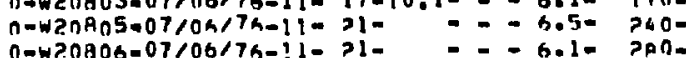
n-w?

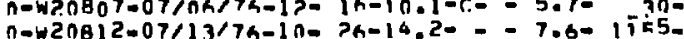
a-Wan A-W20813-07/13/7h-11- 3h-7.8-c- = 6.R- 975

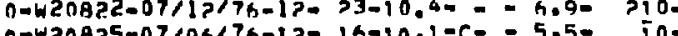

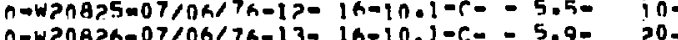
$n=w 20826-07 / 06 / 7 h-13-1 h-10.1-C_{-}=-5.9-$

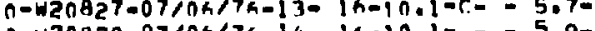
$n=W 2 n A 2 B-07 / 06 / 7 h-14-1 A-10,1=-5.90$
$n=W 2 n 829-07 / 06 / 7 A-14-1 A-10.2-=5.90$

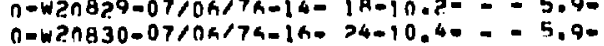
$n=w 2 n 830-07 / 0479-16=24-10.40==5.90$

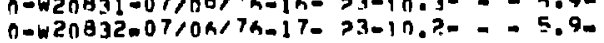

$13-3-6-4-6-3-3-1-2-2-3-3-2-=-$

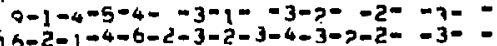
a $=1-9-4-6-2-3-1-3-4-3-2-2=-3-$ $3-1-1-4-6-2-3-1-3-4-3-2-2--3-$ $9-2-7=4-6-4-3-1-2-2-3-3-2-3-3-$

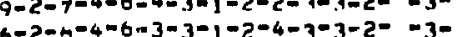

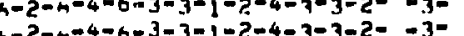
$6-2-4=4-6-3-3-1-2-4-3-3-2-3-3-=$ $12-2-7-4-6-4=3-1-2-2-7-3-2-3-3-$
$9-3-4-4-6-4-4-4-2-4-7-3-2-3-3-$ $9-3-4-4-6-3-3-i=2-4-7-7-2-=3-$ $9-3=4-4-6-4-3-1-2-2-3=7-2--3-2$ $12-3=4-4-6-3-3-1-2-1-2-2-20-3-0$ $=3-A-4-6-3-3-1-1-3-2-4-2-=1=$ $3-3-n-4-6-3-3-2-1-3-4-4-2=-8-$ $3-3-\mu=4-4-3-3-2-1-3-4-4-2--A-$ -3-6-4-6-3-3-1-1-2-7-7-2- - $A^{-}=$ 2-2-7-4-1-2-2-1-1-1-7-3-2- - $A-=$

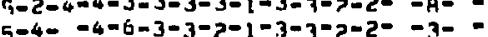
$5-5-4-4=4-2-2-2-1-3-2-7-5-=-1=$

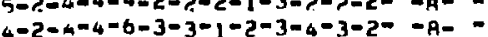
$4-2-4-4-6-3-3-1-2-3-4-3-2-$
$4-2-A-$ $3-2-4-4-6-3-3-1-1-3-7-3-2-1-A-$
$5-2-4-4-6-3-3-1-1-3-3-3-2-$ $5-2-4-4-6-3-3-1-1-3-7-3-2-$
$4-2=4-4-6-2-3-2-1-3-3-3-2-$ $\begin{aligned} & 4-2-4-4-6-2-3-2-1-3-3-3-2--A- \\ & 4-4--4-6-4-4-1-2-4-7-3+2-\end{aligned}-3-=$ $4-2-1,-4-4--3-5--4-7--2-=3-=$ $4-2-1-4-6-4-3-1-2-1-3-4-1-=-$ $6-3-4-4-6-4-3=1-2-1-3-4-1=-1=$ $x-3-4=4-6-4-3-1-2 \times 2-7-7-1=-1=-$ $6-3-7-4-6-2-3-1-2-4-3-7-1=-1-=$
$4-3-4-5-6-3-2-1-2-4-3-2-1--3-$ $4-3-4-4-6-3-3-1-2-1-1-3-2--1=$ $4-3-4-4-6-3-3-1-2-1-7-3-2=-1-=$ 3-3-4-4-6-3-3-1-2-1-3-3-2- - $1=$ $3-2-7-3-6-3-3-1-2-4-3-3-2--1=$ 6-2-7-5-8-3-3-1-2-4-j-3-2--1-: [0-2-1-1-1-4-3-1-3-4-3-3-3-3- =$16-1-4-4-6-3-2-1-2-4-2-3-2 *-3-=$ $3-2-1-5-6-2-3-2--4-2-3-2--3-$
$4-1$ $4-1-1-2-1-4-4-1-3-4-3-3-2--1=$ $4=2-1-2-1-3-3-1-3-1-2-3-2--1=$ $2-2-1-21-4-4-1-3-1-3-3-2--1=$ $4-2-1-4-6-4-3-1--4-3-2-2--1=$ $4-2-1-4-6-4-3-1-2-1-3-3-2--1-=$ $10-3-a-4-6-4-3-1-2-1-3-3-2--1=-$

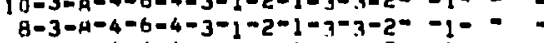
$6-3-4-4-6-4-3-1-2-1-3-3-2--1-=$
7.01
2.74

2.74
3.78

1.74

1. 74

2,5

2,70

0.7

0.19

0.17

0.4

0.10

0.10

0.47

0.10

0.10

0.10

0.10

1.20

0.38

0.10

0.10

0.10

0.10

0.22

0.72

0.14
0.10

$0.10=$

0.10

0.10

0.10

0.10

15.200

4.700

i. ?2

$0 . \overline{0}$

0.10

0.10

0.10

0.10

0.19 
APPENDIX B (continued). Field Data and Uranium Concentrations for Water Samples

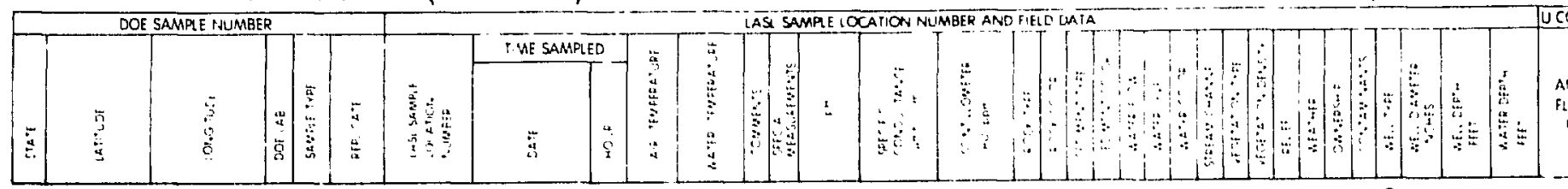
SATERTE

$36-A 1$, TAB $1-10 R .052 R-2-0 \mathrm{H}-$ $30-41.4211-104.0575-2-09-$ $36-91.8592-104 \cdot 0886-2-07$ 56-41. $0683-104 \cdot 0542-2-07-$ $56-61.6194-104 \cdot 0486-2-06-$

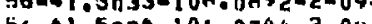
$56-41.5994-104,0744-2-09=$ $56-41.5519-106.0942-2-07=$ 56-61.9064-107.1481=2-07$56-41,00 R 7-107,1394-2-06-$
$56-41,3992-107,1311-2-10-$ $56-61.36)_{1}=107.1272-2-07$ $56-41,330$ - $107: 158 \mathrm{~h}-2-07=$ $56-4[.3 \cap A 1-107 \cdot 131\}-2-07=$ S6-4l. $25 ? 9-107.1163-2-07$ $56-41: 1614=107: 167 ?-2-07=$ $56-41$ 2n94-107.1661-2-07 $56-41$. $2044-107 \cdot 1989-2-06$ 56-4l.202月-107,1469-2-07= $56-41+2594=107 \cdot 2308=2-07-$ 56.41.2772-107.2253-2-07 56-4l. ¿कA] - 107.2169-2-07 $56-41.2975-107.2006-2-07-$ $56-41.057+2-107.2 A 28-2=07=$ $56-41.0614-107.2947-2-07=$ 56-41.0778-107.3061-2-10 $56-41.0062-107 \cdot 3031=2-07$ $56-41.0042-107 \cdot 3031-2=07-$ $56-41.0194-107.1560-2-07=$ 56-4 1.0353-107.2264-2-07= $56-41.1452-107.4289-2-07=$ $56-41.1453-107-427=-2=07$ $56-41.1333-307.4144-2-06$ $56-41,1372-107-3892-2-07$ 66-41 $5775-1040729 ?-2-07-$ $56-4105753-100.7300-2-07$

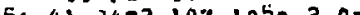
$56-41,34$ ?2-107, $105 \beta-2-07$ $56-41.3494-107.1$ A $31.2=2-07$ $36-41,3 A B 3-107,0 R 0 A-2-07-$ $56-41.4167-107.0050-2-47-$ $56-41 \cdot 4458-107 \cdot 0383-2-07=$ $56-41,1579=107,4072-2=06-$ 56041.1 . $36-41.2178-107-4411-2-06-$ $56-41.2>33-107 \cdot 6191-2-06-$ $56-41.2417-107.4561-2-06$ $56-41,2442-107,4272-2-07-$ $56-41,4183-107 \cdot 2903-2=07-$
$56-41,1100-107,9269-2=07-$ $36-41.0347-107.5009-2-07$
n-W2nB35-07/00/74-15- 13- $9.0-=-6.9-909$ $n=w 2 n 840=07 / 10 / 7 h-10=26-10.7=-5.9 m 17 n n-$

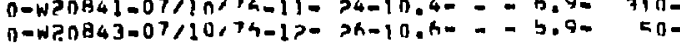

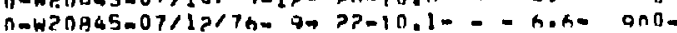

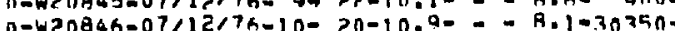
D-w20948-07/2/7h-11-32-10.9- = - 6.3m 1391-W20A48=07/1?/7h-1] $22-10.9=-6.3=139$

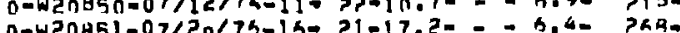

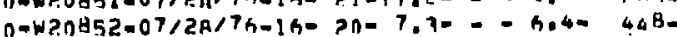

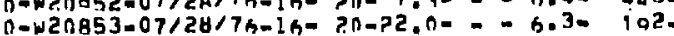
$n-w 20854=07 / 2 A / 7 h-1701 A-17.5-2=6.403>0-$

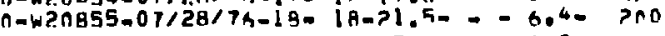
D-WZOB56-07/2A/7A-1A- 1A-17:D- - h.3- 3KD n-W20R57-07/29/7h- 9- 13-7.1- - - 5.50 342 O-WP0858-07/20/7h-1n= 16- 8.4- - - 5.9. in3 $n=W 20859-07 / 26 / 7 h-1 n-15-10.70=-5.7-$ 5 5 $n=w 2 n 860-07 / 29 / 7 h-1>0,15-1004=-5.4=\quad 42-$ n-w2nB61-07/29/7h-12- $\mid h-11.0--5.7-55$ n-W20862-07/29/7h-13- 30-1A.2- - = A.R- 405$0-W 20863-07 / 29 / 74-14-21-10.9==6.70312-$ n-W?n864-07/29/7h-14m P1-1月.11- = h.3- iA3 D-W20865-07/24/7h-15- P0-16.5- - - 6.7- 402 $0-W 20866-07 / 29 / 7 h-12-77-1 A_{1} 1=-6.50$ AnDO $0-W 20867-07 / 29 / 76-12-3 A-32.9+=0.90$ 4KD0-W20869-07/29/7h-17- 79-24.9- - - 7.A. j05$0-W 20870-07 / 29 / 7 h-14 n$ 2h-18.5-C- - 6.6- $450-$ n-W20871-07/29/7h-14-37-14.5e- - h.3= $2 \times 9=$ O-W2D872-07/24/7A-15- 2A-1B.9- - - 6.10 i31$n=W 20874=07 / 29 / 7 h-1 h-27-23.9 n$ - - hol: $Q 2$ $0-W 20877-07 / 29 / 76-1 A=17-23$ ?- = - 6.8- 4i5

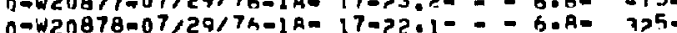
$n=W \angle 0879-07 / P 9 / 76-18-17-19.1-=-6.8$ - AnO-

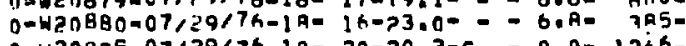

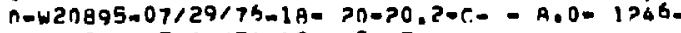
(1)W20896-07/2A/7h-19+19-17.1) - - + D=W20898-07/29/75-14- PP-17,4- = - 6.3- 252-

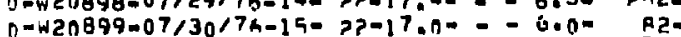
$11-W 20900-07 / 3 n / 7 S-16-23-\quad=-6.40370$ naw20804-07/3n/76-17- $21-19.00=-606=$ 990-

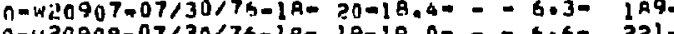
n-W20908-073n/76-18-19-19.n=-6160 321 O-W20915-07/3n/7A-1A- 17-2h+n=- = 7.1- 2nOD n-w2 n-weng18-07r3n/7h-19- 17-2.3.2- = - 6.9- 459 0नWद0919-07/3017h-19- 17-25.5- - - 6.A. CA5 0-we

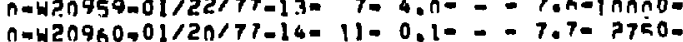

$12-4--5-6---1-3-4-2-3-2--1-3-a_{-}$
$4-3-1-5-6--2-2--4-7--1--3-$

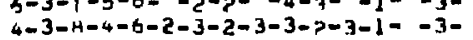
$4-3-1-4-6-2-2-2-3-3->-3-1=-3--$

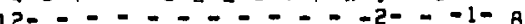
$4-5-1=4-6=-5-1=-4-5=-5-3-3-1=$ h-4- $=-5-4-6-3--4-3=-2-3-3=$ $1-1-1-4-6-2-3-1-1-3-3-3-2--3-$ $1-1-1-3-7-2-3-1--3-3-3-2--3-$ $6-1=1-4-6-5-3-1-1-3-7-3-5-1-1-$ $-2=7-4-6-2-3-1-3-3-4-3-2--3=$ 9-4- -5-6-2-2-1-3-1-3-3-2- -3$13-1-1-3-6-3-3-1-2-1-4-2-2-=-8-$
$1 n-2-n-3-6-2->-1-3-4-3-3-3-=-8-$ i $6-2-6-3-6-3-2-1-2-1-4-3-3-3-B-$ i $6-2-7-4=6-3-3-1--1-4-3-3-=A-$ $16-2-7-3-6-3-3-1-2-1=-4=7-3-1-8-$
$3-4--4-6-3-3-1-2-3-3-7-2-3-$

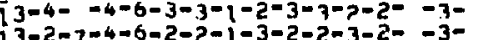
$19-2-7-3-6-3-3-1-2-3-3-3-2-3-7-$ $19-4--5-6-2-2-1-3-2-3-7-2--3-$ $6-2-7-4-7-2-3-1-1-4-7-3-2-1-$
$3-4-=4-6-2-3-1-1-4-3-3-2-1-$ $3-4--4-6-2-3-1-1-4-3-3-2--1-$
$6-3=1-5-6-1-3-1--3-2-5-2--1-$ $3-1-1-5-7-3-3-1-1=3-2-4-2-=9=$ $3-3-4-1-8-2-3-1=1-2-4-5-2-1-$
$6=3-4-4-6-3-3-1-1-2-3-5-2-1-$ $6-2-7-4-6-3-3-1-1-2-7-5-2-1-$ $0-1-6-5-6-2-3-2-2-3-3-5-2=-3-$ $9-1-7-4-6-2-3-1-1-3-2-5-2--3=$
$3-2-7-5-6-7-3-1-1-3-7-5-3--3=$ $6-2-7-5-6-3-3-3-1-3-2-5-3-=3-$ A-4- -5-6-2-2-3-1-4-4-4-4- -3$16-3-7-2-1-3-2-2-2-3-3-4-4=-3-$ $11-4--5-6-3-2-1-3-3-3-2-2--3=$ $16-4--4-7-3-3-1-3-3-4=3-2=-3-$ $13-4--5-6 m 3-3-2-2-3-3-2-2-=3-$ $13-4--4=6-2-3-1-3-3-3-7-2=-3-$ 1 $19-4-1-4-6-3-3-1-2-3-1-3-3-3-2-2=-1-$ $9-4-0-5-6-1-3-1-1-4-2-3-2-1-3-$
$0-4--4-6-2-3-3-1-4-4-5-20-1-$ 6-1-1-5-6-2-3-1-1-3-7-5-2- -1$n-4--5-6-2-3-1-1-3-2-4-2--1=$
$6=4--4-6-3-3-3-2-4-3-4-2-3-$

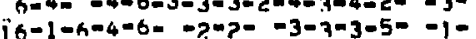
$16-1-6-4-6-3-3 m-3-3-3-5--1=$
$19-1-n-5-6-3-3-3-3-3-1--10$

0.10

0.10

0.10

0.43

0.17

3.40

1.77

0.10

0.91

2.08

$0 .{ }^{\circ}$

0.55

1.21
1.24
0.10
0.10

0.10

3.74

3.43

2,42

3.72

1.46

0.37

4.50

$13.00 \%$

0.46

7.32

0.10

0.49

1.42

1.08

$7 ! .70=$

10.90. 


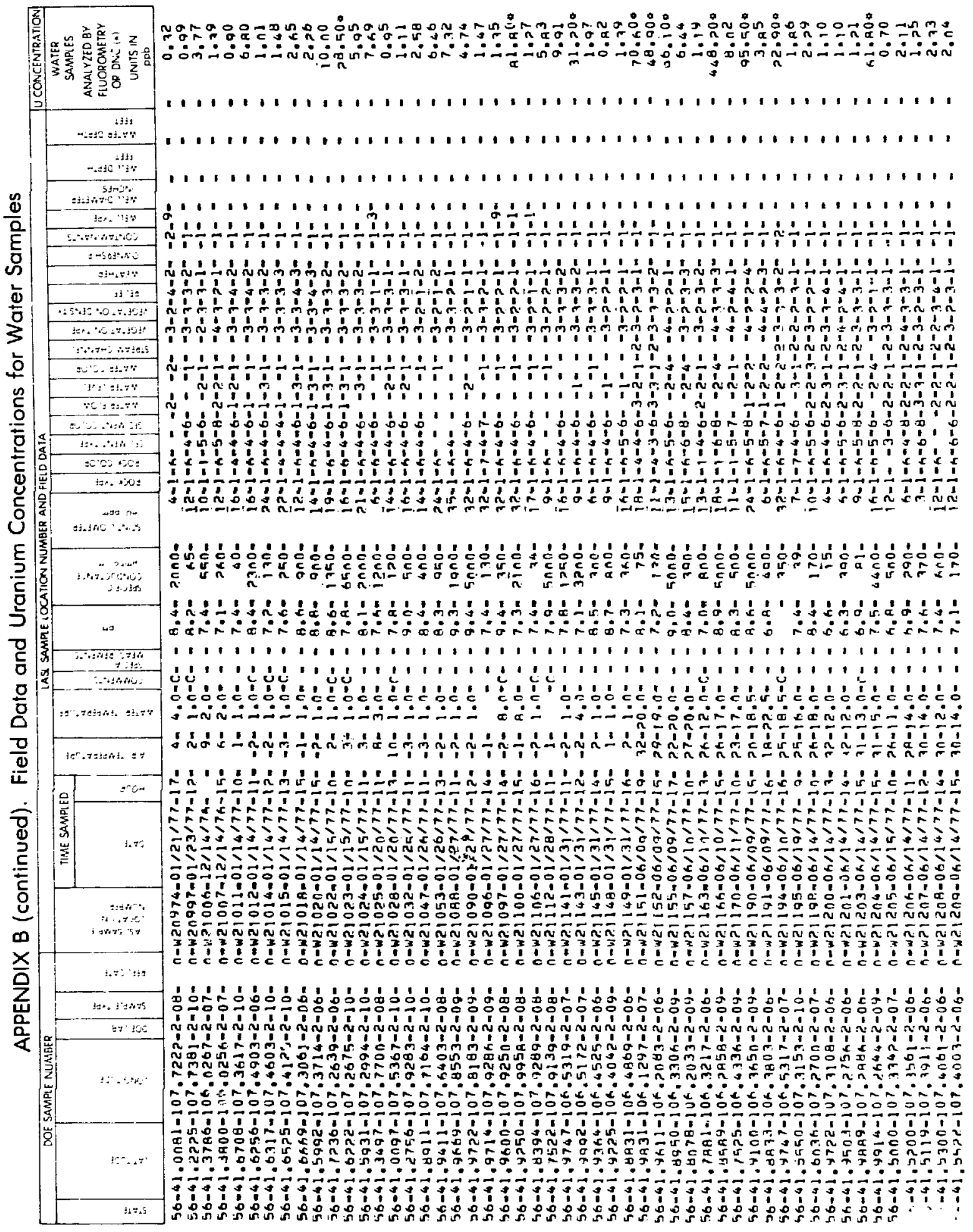


APPENDIX B (continued). Field Data and Uranium Concentrations for Water Samples

w

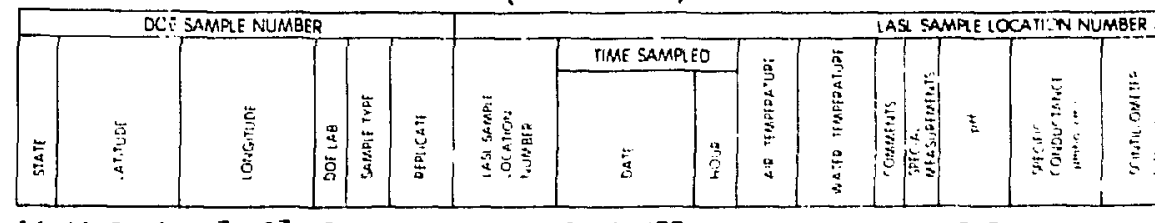

$56-41.5681-107 \cdot 3972-2-10-$ $56-41,3342-107.4469-2-06-$ $56-41.5269-107.4654-2-n 6-$ $56-41,5944-107,3256-2-10-$
$56-41.8097-107,2939-2-10=$ $56-41.8097-107.2939-2-10=$
$56-41,6139-107.2933-2=06-$ $56-41,8139-107,2933-2-06-$
$56-41,6361-107,3186-2-06-$ $56-41 \cdot 8422-107 \cdot 3561-2-06-$ $56-41.8731-107 \cdot 3667-2-06=$
$56-41,8700-107.3425-2-06-$ $56-41=4700=107.3425=2-06=$ $56-41,75 A^{3}-107,0967-2-09-$ $56-41.6438-106.6725-2=07-$
$56-41.6311-106.6456-2-06-$ $56-41.6311-106.6456-2-06-$
$56-41.6778-107.0997-2-06-$ $56-41.6778-107 \cdot 0997-2-06-$
$56-41.6953-107.1314-2-06=$ $56-41.6547=107.2039-2=06=$ $56-41.6525-107+2172-2-06=$ $56-41.555841070206=2=06=$ $56-41.6981-107.3294-2-06-$ $56=41.6756-107 \cdot 3297-2-06=$ $56-41.6567-107.3453-2=06-$
$56-41.6406-107.3789-2-06-$ $56-41.6406-107 \cdot 3789-2-06-$ $56-41.5900-107.4181-2=06=$ $56-41.5900-107.4181-2=06=$
$56-41,5628-107.4650-2-06=$ $56-41,5628-107.4650-2-06=$
$56-41.6011-107,5075-2-10=$ $56-41.5039-107.4653-2-06=$ $56-41.1075-107,4894-2-10=$ $56-4 !, 74 ; 3-\{07,459 !-2-10=$ $56-41.5656-107.5136=2-06=$ $56-41.4769-107.3833-2-06$. $56-41$. JH42-107. $4011=2-08$ $36-41.4517-107.4169-2-10=$ $56-41,1089-106.6039-2-10-$ $56-41,1350-106,5292-2-06=$
$56-41.0461-106,8003-2-07=$ 56-41,0594-106.8056-2-07$56-41.0686-106.8000-2-07=$ 56-41:1775-106,7883-2-07$56-41$. 1 A56-104. B492-2-06$56-41$. IA19-10R, B408-2-07$56-41-2292-106.6017-2-06-$ $56-41.1069-106.7861-2-07=$ 56-41.1347-106.7A25-2-07= $56-41.1196-104,7 A 0.3-2-07-$ $56-61 \cdot 1967-107.8956-2-06-$ $56-41 \cdot 2347-107.5717-2-06=$ $56-41.0774-106.4628-2-06-$

n-W21210-08/14/77-15-70-16.0- - A.5-34nnn-W21211-06/14/77-16-30- =- - B.A- 2050-W

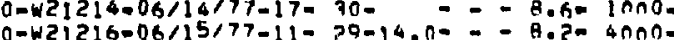
ด-w2 1-W2 $1217-00 / 15 / 77-11=39-13.0=-=7.004500$.

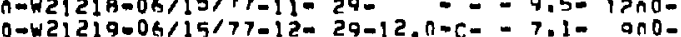
$0-W 21219-04 / 15 / 77-12-29-12.0-c=-7.1-$ ano-

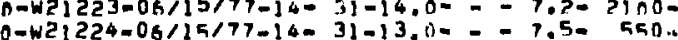

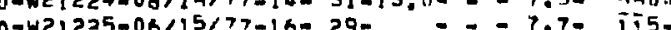

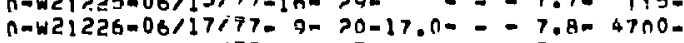

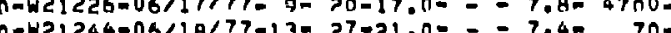
n-

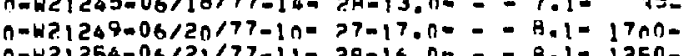
A-W21257-0h/21/77-14m 3A-12.n-C=-7.?- $1100=$ A-W21258-0h/2, /77-14- 2A-17.0- - - 8.4- 3ino-

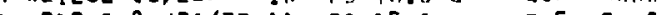
$n-w 21278-06 / 20 / 77-11-2 n-15 . n=-7.5-27 n 0=$ O=W21279-06/21/77-12- 22-11.00--6.A- 320n-W21 282-06/21/77-15- 25-11.0- - - 5.1- 05-

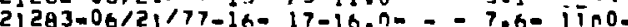
0-W21285-06/22/77-10- 32-19.0- - - 3.0- 540(-W2) $287=06 / 23 / 77-12025-12.00=-7,1=9 a 0-$ $0-W 21288-06 / 22 / 77-15-26-22.0=-9.1$ - 1AnO-

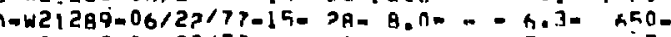
$0-121293-06 / 23 / 71-104>6-16.04=-7.4-4650$

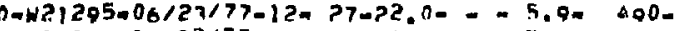

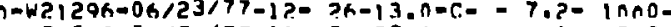

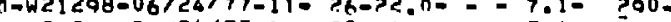

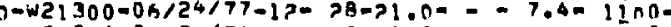

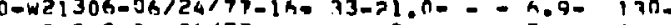
n-W2 308-0h/26/77-11- 26-18.0- - 7.2- 270-

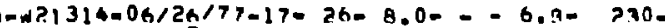
n-W n-W2] 316-06/27/77-12- 2?-9.0- - - B.A- T5. n-W21317-0K/27/77-12- 22-9.10- - 6.7- 50ก-W21318-0h/2A/77-11- 36- B.n- - - 7.2- pioA-W21319-06/26/77-:3- $77-18.0-=7.70$ - $770-$ O-W? $1320-06 / 24 / 77-14=37-14.0=-$ - 7,0- $310-$ $0-W 21321-06 / 26 / 77-15-34-9.5=-60 A-44 \pi-$ O-W? $1322-06 / 27 / 77-150$ - P - 5.5- - T.1- 100A-W21323-06/27/77-14- P1-15.6- - - 6.A- 4nn-w?1324-06/27/77-14- 37-15.n-E-6.6- 45. 管 $0=W 21334=06 / 24 / 77-11$ + 3n-1K.n- - A, $n-1350-$

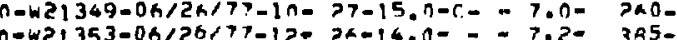

$12-1-n-5-6-2-2-1-2-3-3-4-1--1--$ $8=1-x-6-8-2-2-1-2-3-2-3-1--1=$

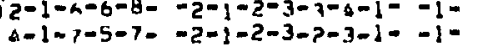
$4-3-7-4-8--2-1-2-4-2-4-1=-1=$ 3-3-7-5-8-2-3-1-2-4-2-4-1--1-

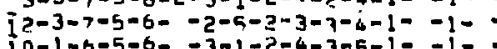
$14-1-6-5-7-2-2-1-2-3-7-7-1--1=$ $11-1-h-5-h-2-2-1-2-4-7-4-1=-1=$ $15-1-1-5-7--2-3-2-3-3-4-2=-1=$ $19-1-6-4-6-3-2-3-2-3-3-2-1--1=$
$19-1-1$ $4-1-6-5-6-2-3-1-2-4-7-7-1--1=$
$15-1-6-5-7-2-2--2-3-7-3-2-1-$ $15-1-n=5-7-2-2--2-3-1-3-2-1=$
$18-1-1-6-6-3-3-1-2-3-2-3-1-1=$ $13-1-x-3-6-2-2-1-2-3-2-3-2--1-$
$18-1-1-6-6-3-3-1-2-3-2-3-1-1-$ $6-1-6-6-8-2-2-1-2-4-3-7-2--1-=$ q-1-n-6-8-1-3-2-2-4-7->-1--1- = $6-1-4-6-8-1-3-2-2-4-7-7-1=-1=$
$6-1-6-6-8-1-3-5-2-7-3-3-1=-1=$ $14-1-6-6-8-2-3-1-3-4-3-2-2--1=$
$0-1-6-5-6-1-3-1--3-2-3-2--1=$ $15-1-h-6-8-1-3-1-2-4-3-3-4=-1=$ $15-1-n-5-6-1-3-1-2-3-3->-1--1-=$ B-1-k-5-8-2-3-1-2-2-7-7-2- -1-

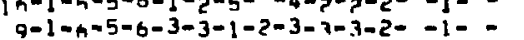
$15-1-n-5-6-1-2-4-3-3-3-2-1--1=$
$9-1-h-5-6-3-3-1-2-3-7-3-2-1-$ $12-1-n-5-7-1-3-4--4-2-2-1=-1=$

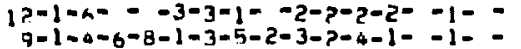
$9-1-4-6-8-1-3-5-2-3-7-4-1--1-=$
$9-1-1-6-8-2-3-1--3-9-7-1--1-=$ 16-1-7-6-7-1-3-4- -3-2-3-2- -1- $j 6-3-4-4-6--3-1--1-3-4-1--1-=$
$9-1-7-4-6-2-3-1-2-4-7-3-2--1=$ $9-1-7-4-6-2-3-1-2-4-7-3-2-1-1=$
$13-3-n-4-6-3-3-1-2-2-7-4-1-1=$ $30-3-n=4-6-3-3-1-2-4-3-5-1--1=-$ $3-3-n=4-6-3-3-1-2-1-3-4-2--1-=$
$i 9-3-A-4-7-2-2-1-2-2-3-5-1--1=$ $34-3-A-5-B-2-2-1-2-4-4-4-2=-1-=$ $72-3-4-5-8-2-2-1-2-4-7-5-2--1=$
$21+1-1-4-6-2-2-1--4-4-3-2-1-=$ $21+1-1-4-6-2-2-1--4-4-2-2--1-$
$4-3-1-4-6-2-2-1-2-5-4-5-2-$
$3-1=-$ $10-3-a-4-6-3-3-1-5-2-4-4-5-1=-$
$30-3-a-4-6-3-3-1-2-2-3-4-5-1=$ $15-3-4-4-6-3-3-1-2-2-3-4-2--1=$
$10-3-4-5-8-3-3-1-2-3-7-4-2-1-$

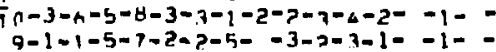
$9-1-1-5-7-2-2-5--3-2-3-1--1=$
$1-1-n-6 \cdot 3-2-2-4=-3-7-3-1--1=$ $3-3-4-5-6-3-3-1--3-3-3-2--1=$
$7-3-4-5-6-2-3-1=-3-7-3-1-1-1-$ 
APPENDIX B (continued). Field Data and Uranium Concentrations for Water Samples

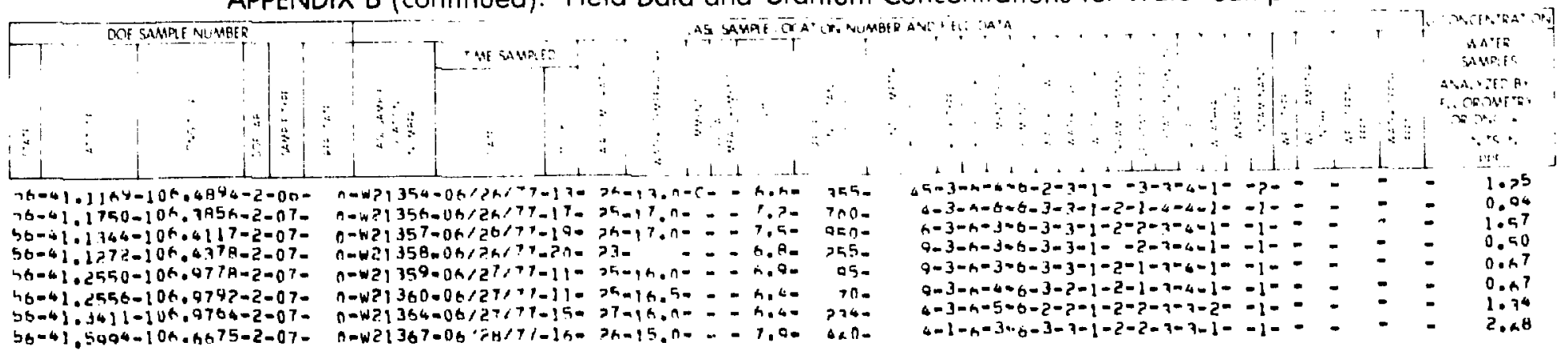


APPENDIX C

LISTINGS OF FIELD DATA AND URANIUM CONCENTRATIONS

FOR SEDIMENT SAMPLES

(See Appendix $D$ for Code to t,istings) 


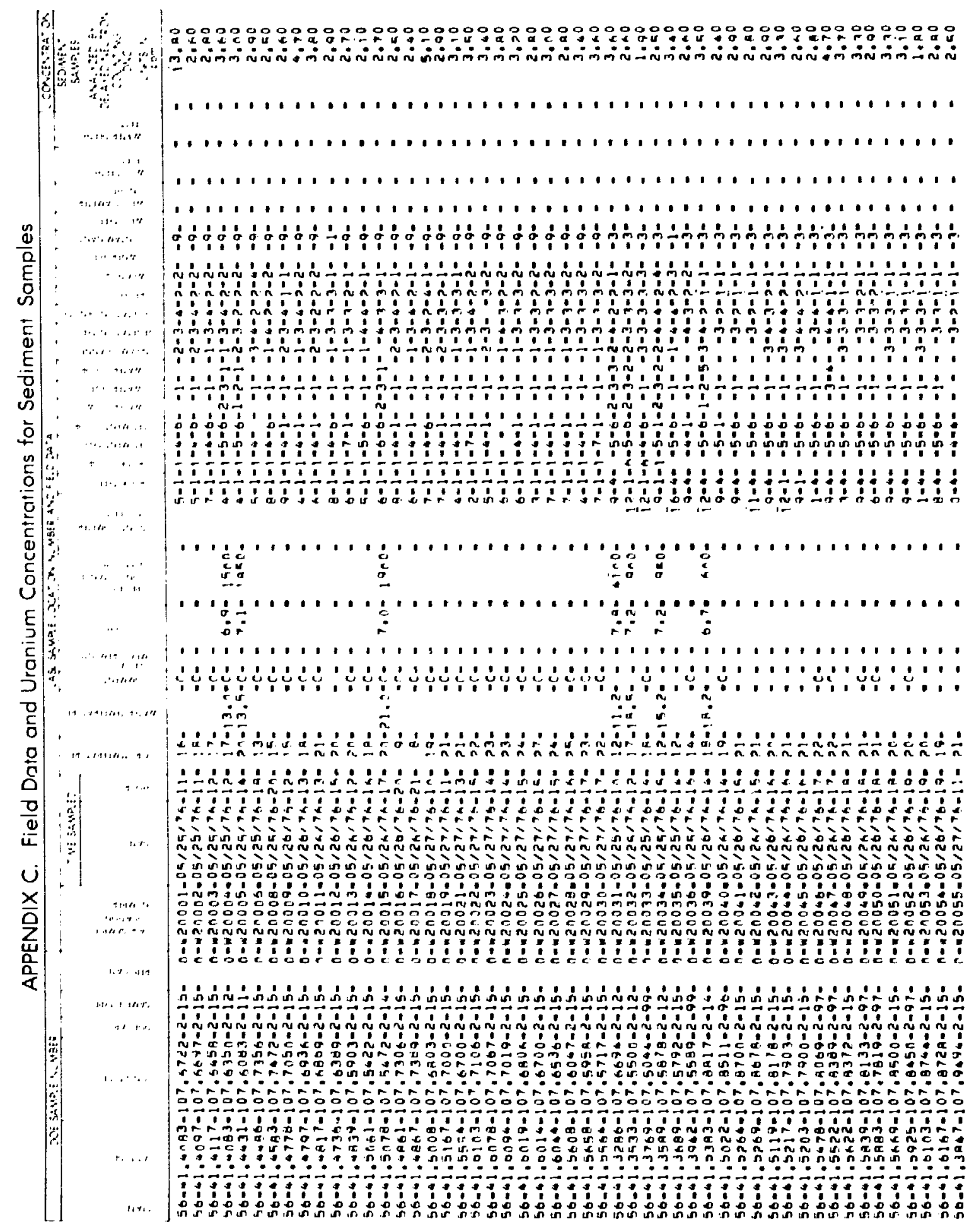









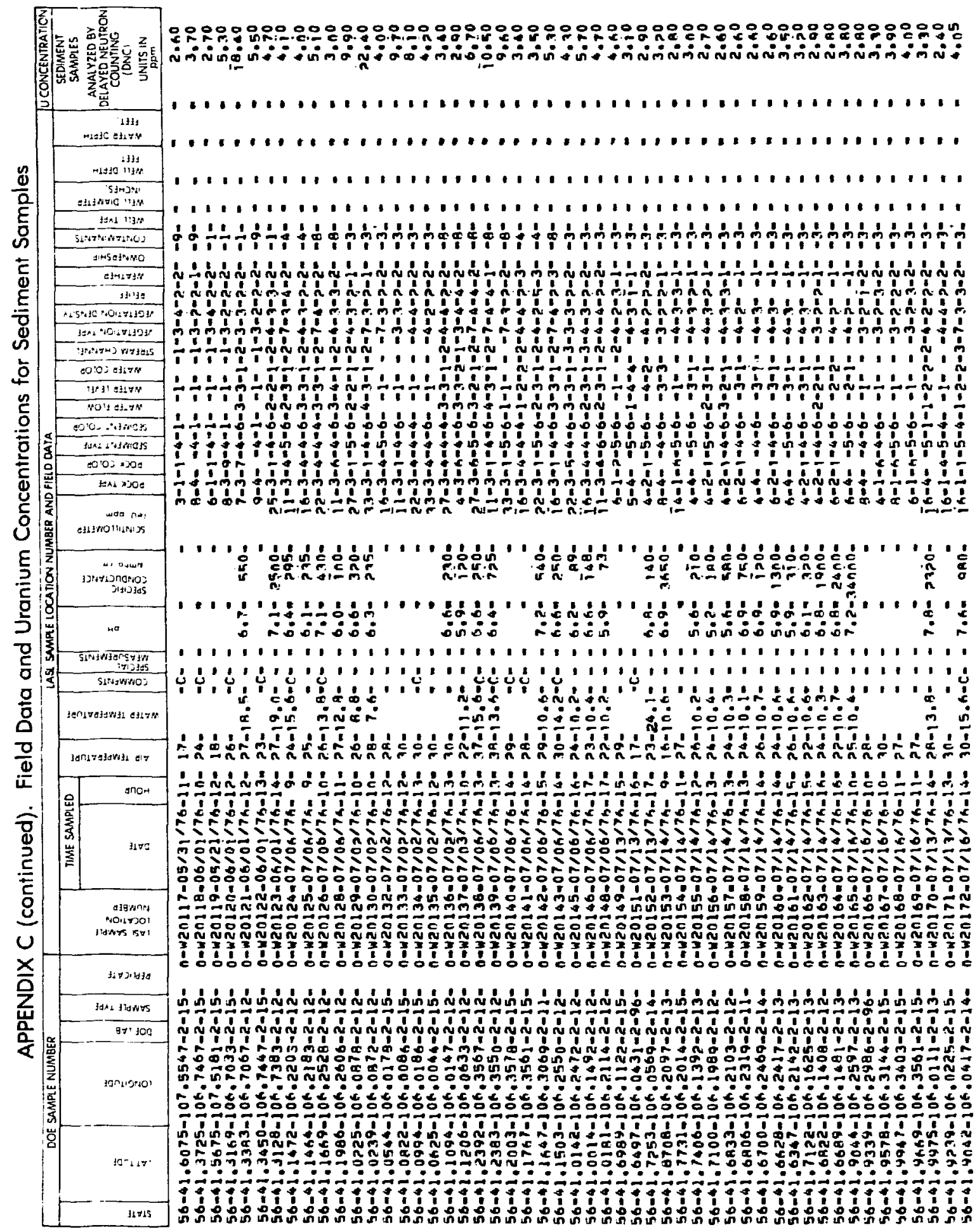




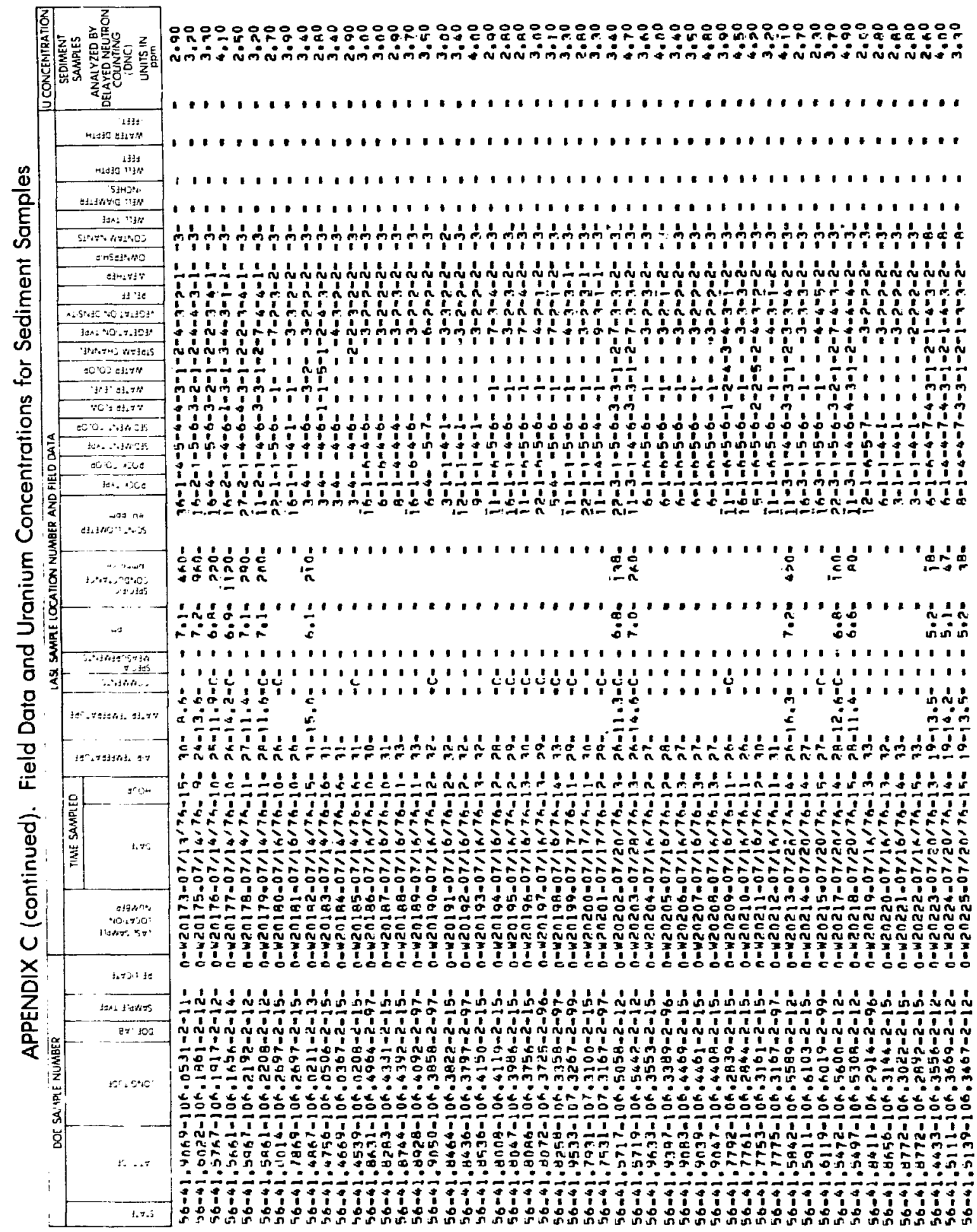




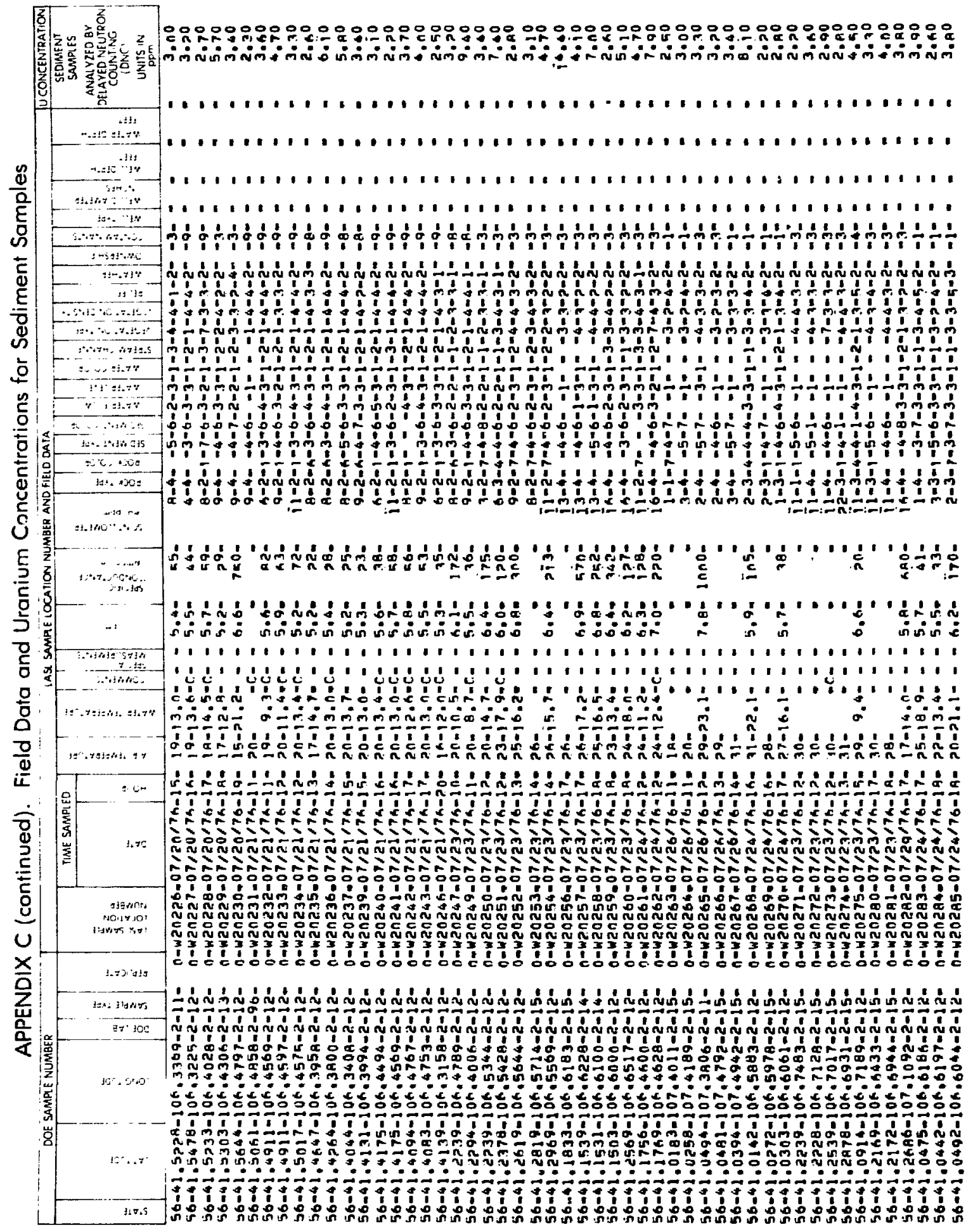


APPENDIX C (continued). Field Data and Uranium Co:centrations for Sediment Samples

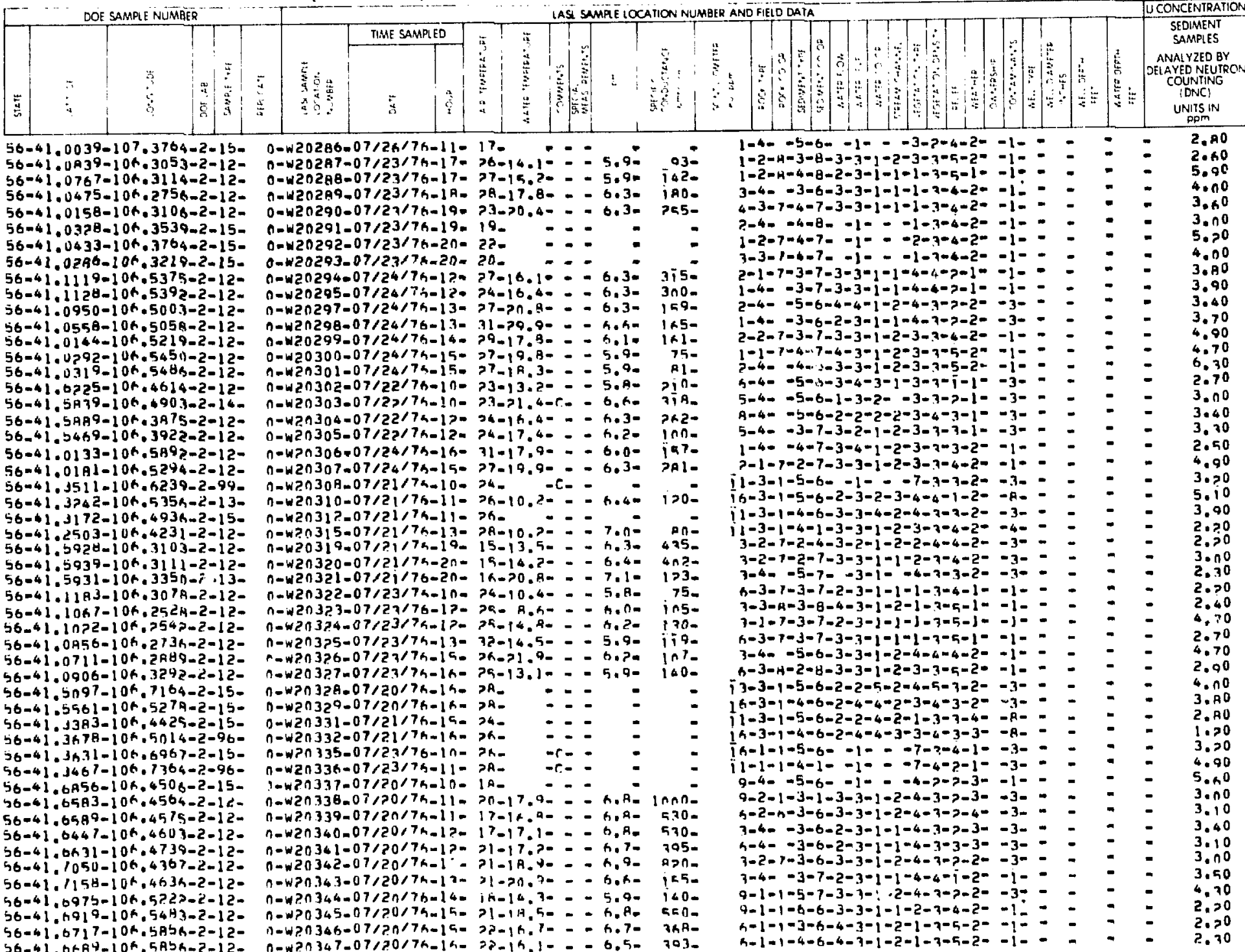




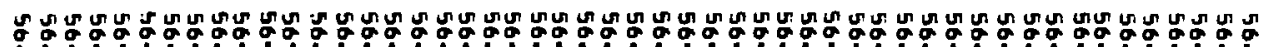

mutw

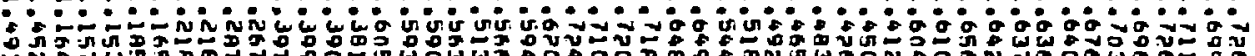

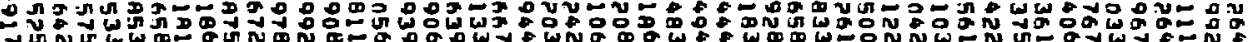

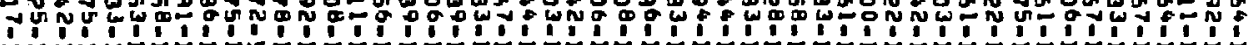

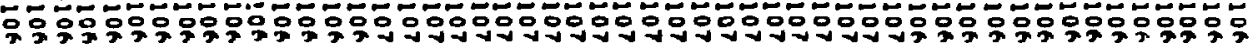

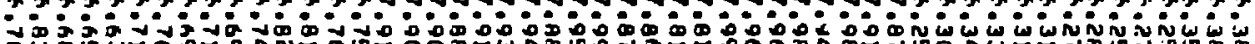
س ०

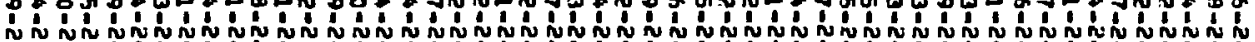

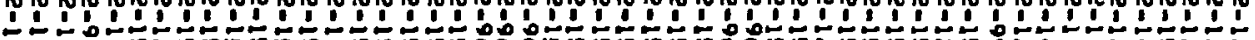

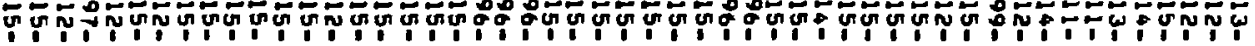

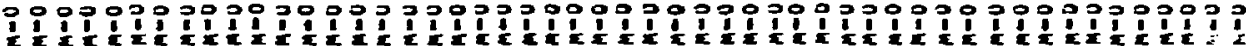

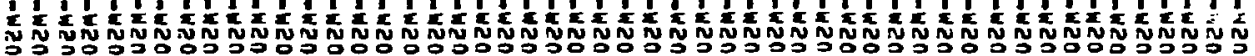

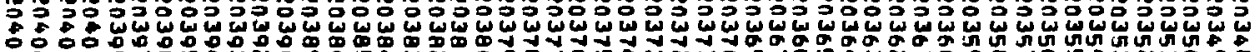

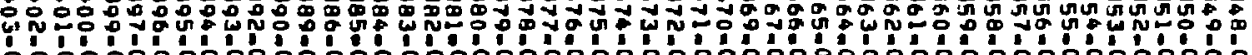

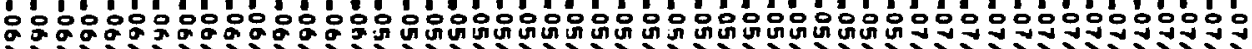

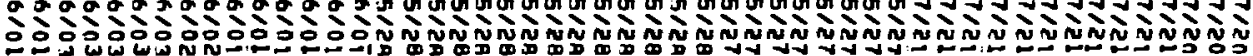

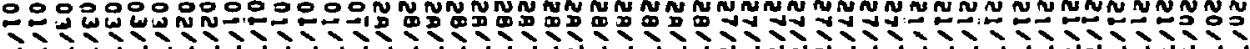

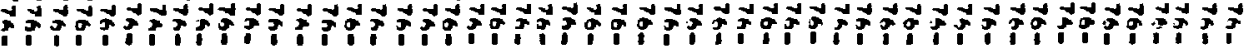
В

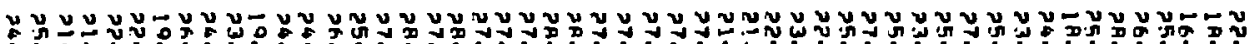
:

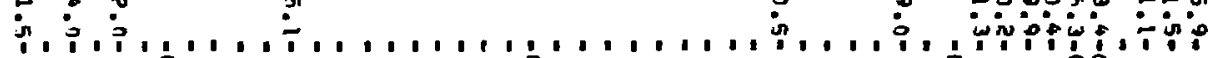

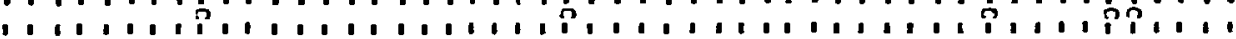

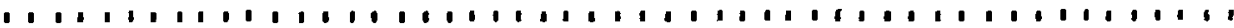
ํ.

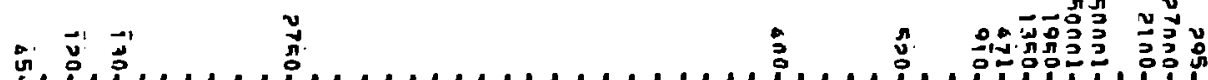

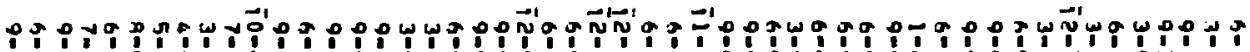

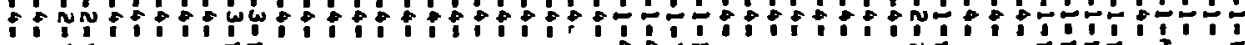
: :

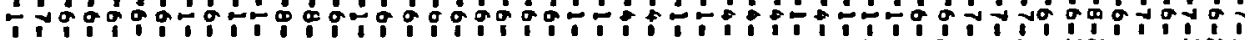

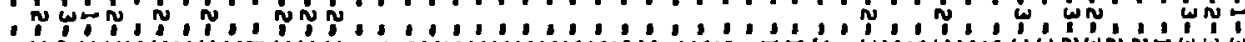
7 1 Y

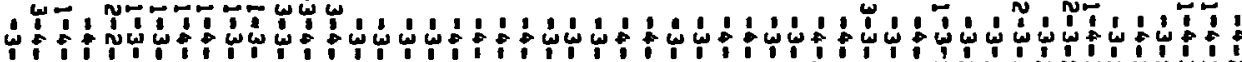
1 $\overrightarrow{1}, 1$ :

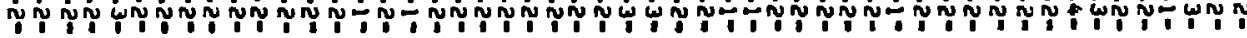

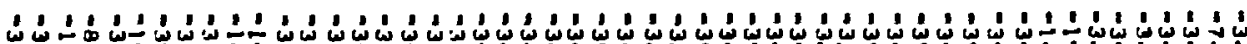

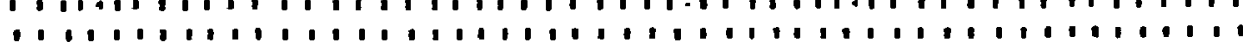

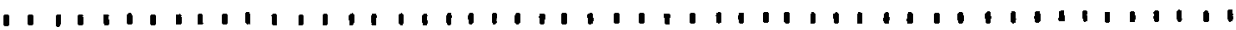

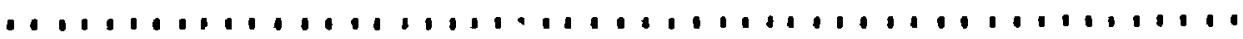

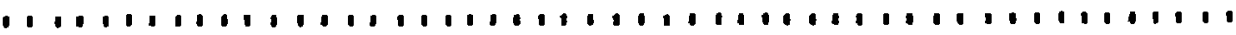
N

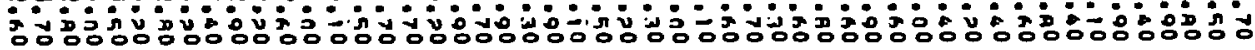

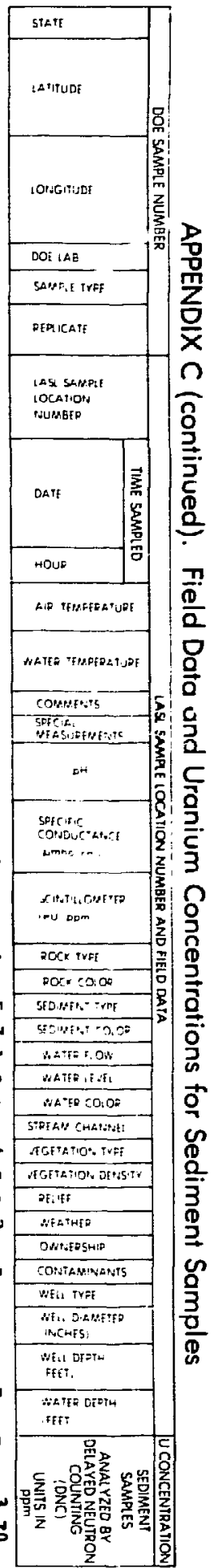




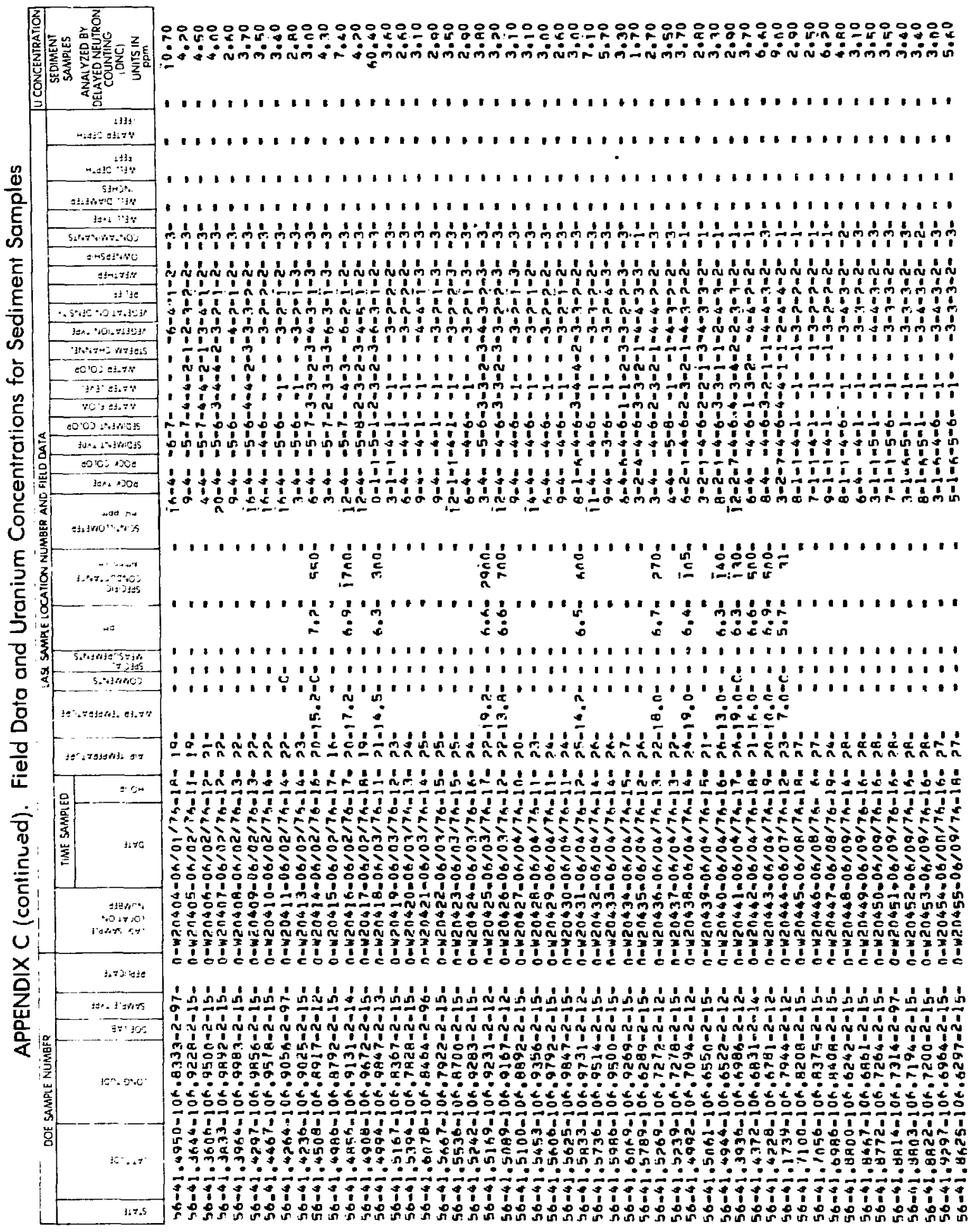


APPENDIX C (cantinued). Field Data and Uranium Concentrations for Sediment Samples

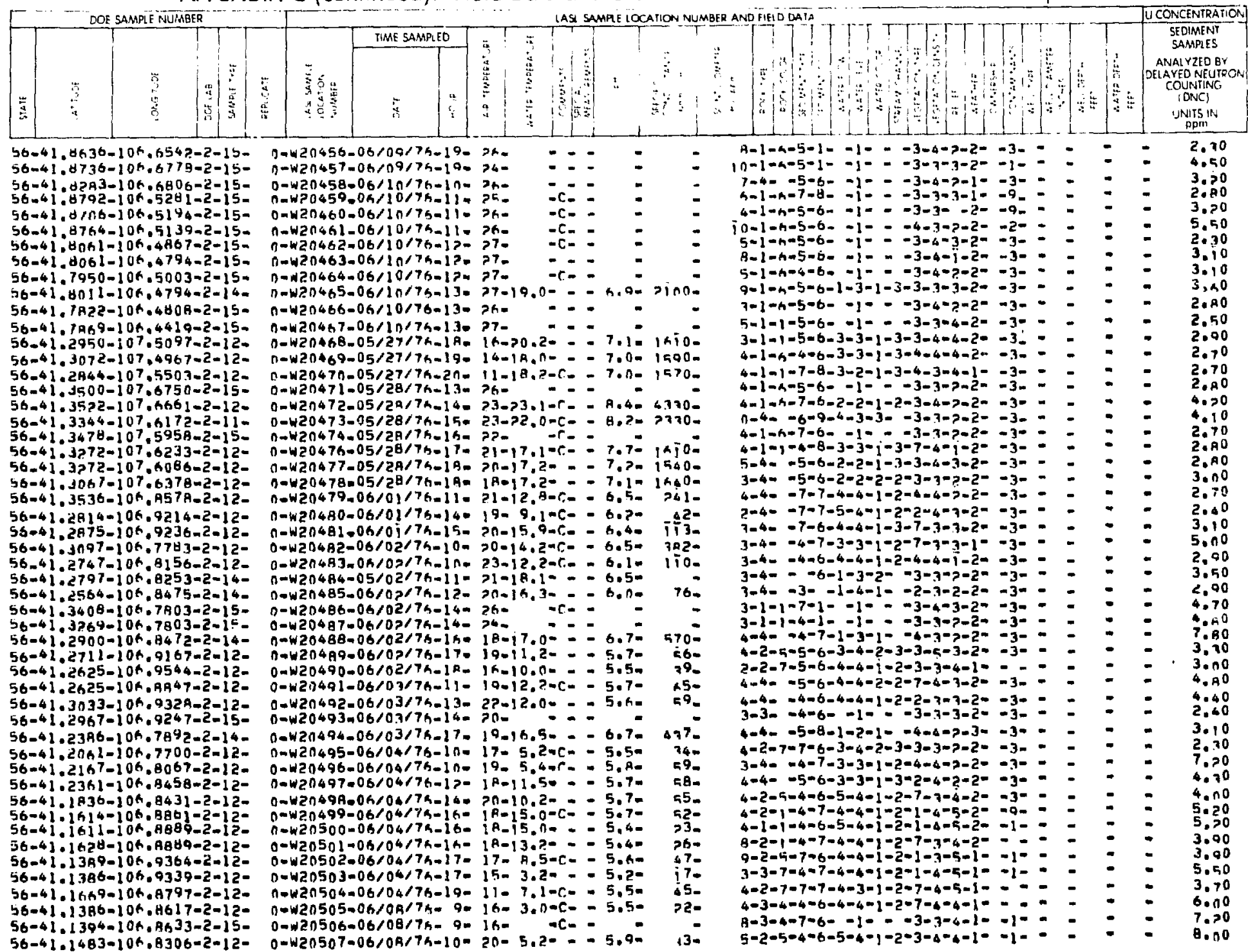


APPENDIX C (continued). Field Data and Uranium Concentrations for Sediment Samples

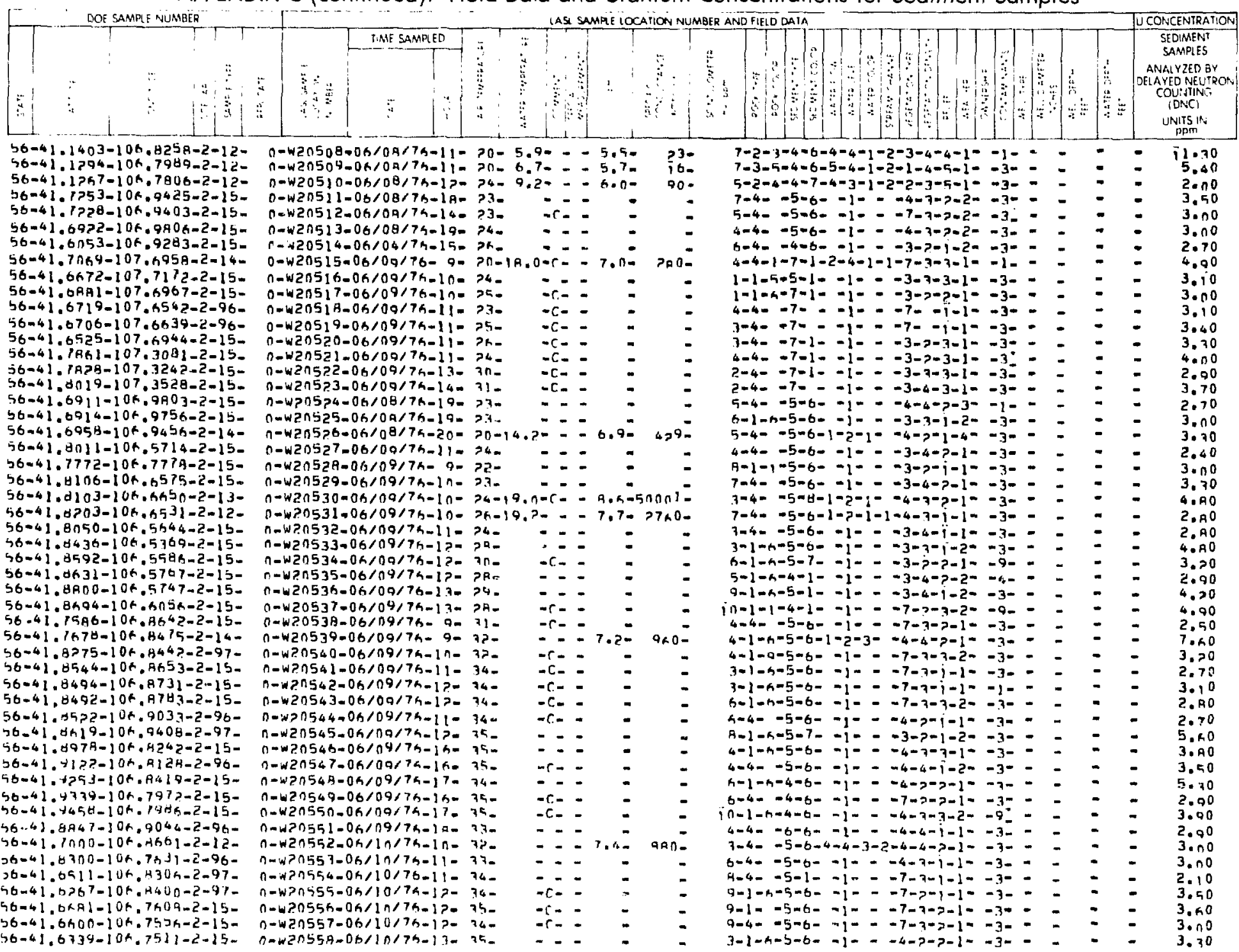




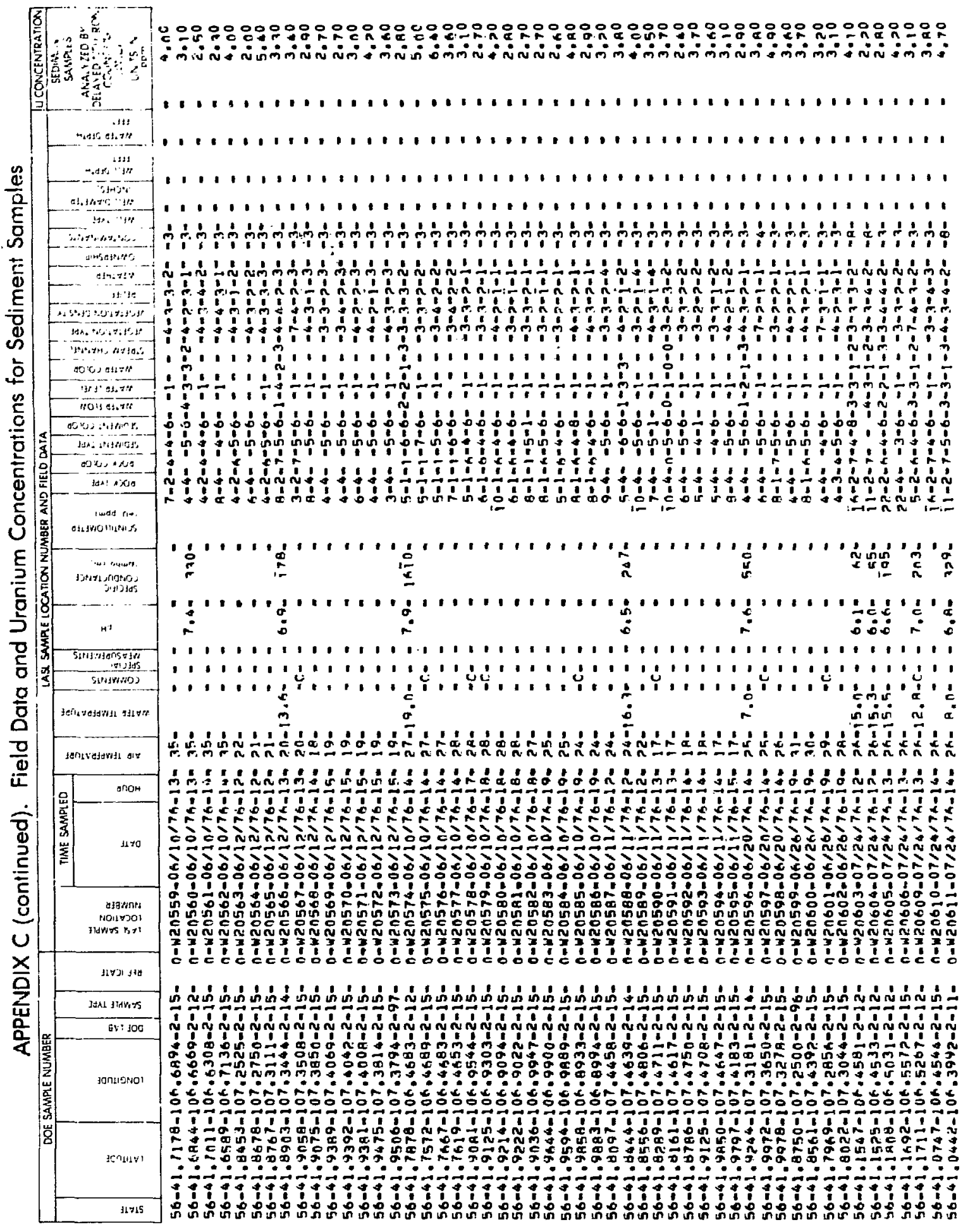




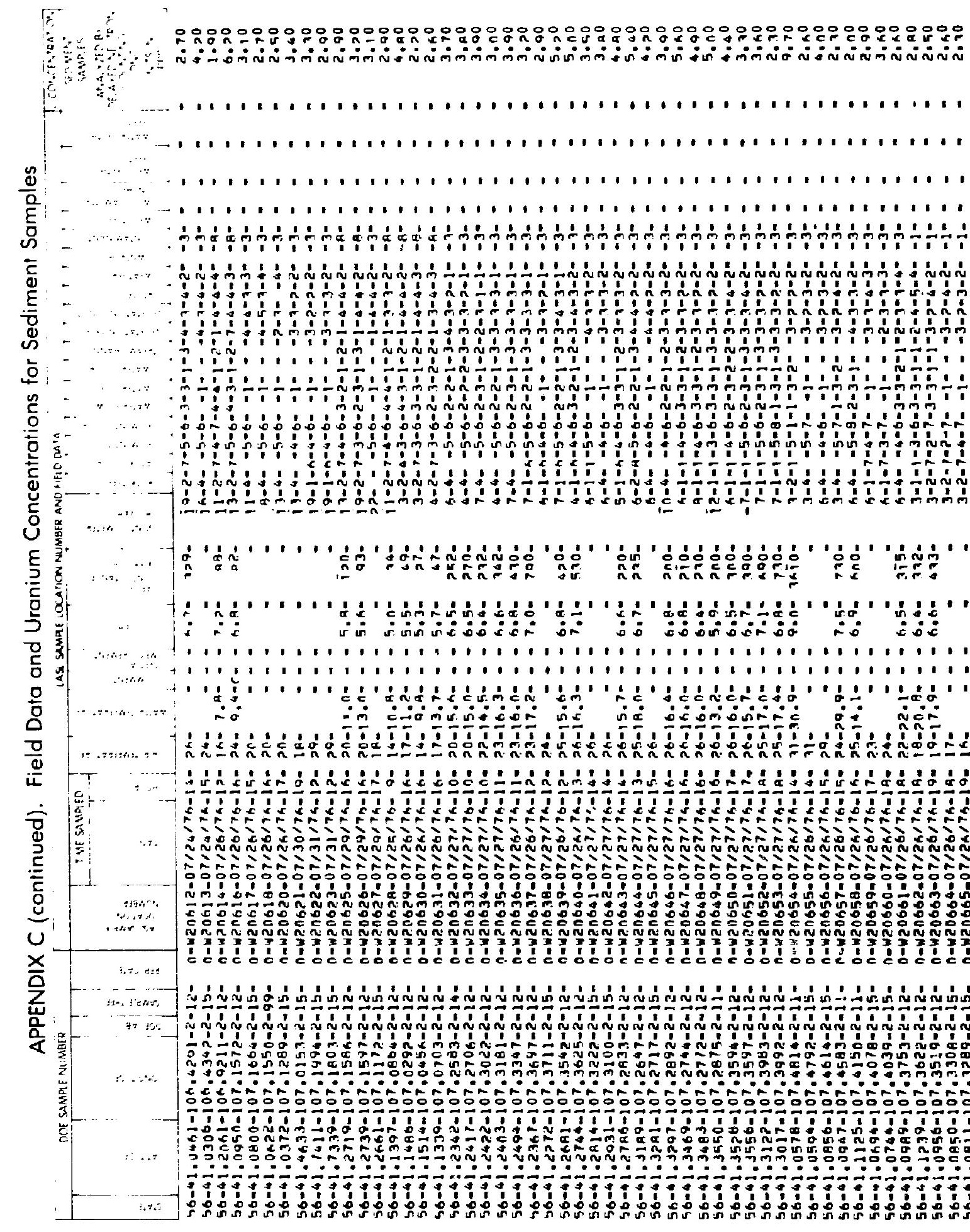




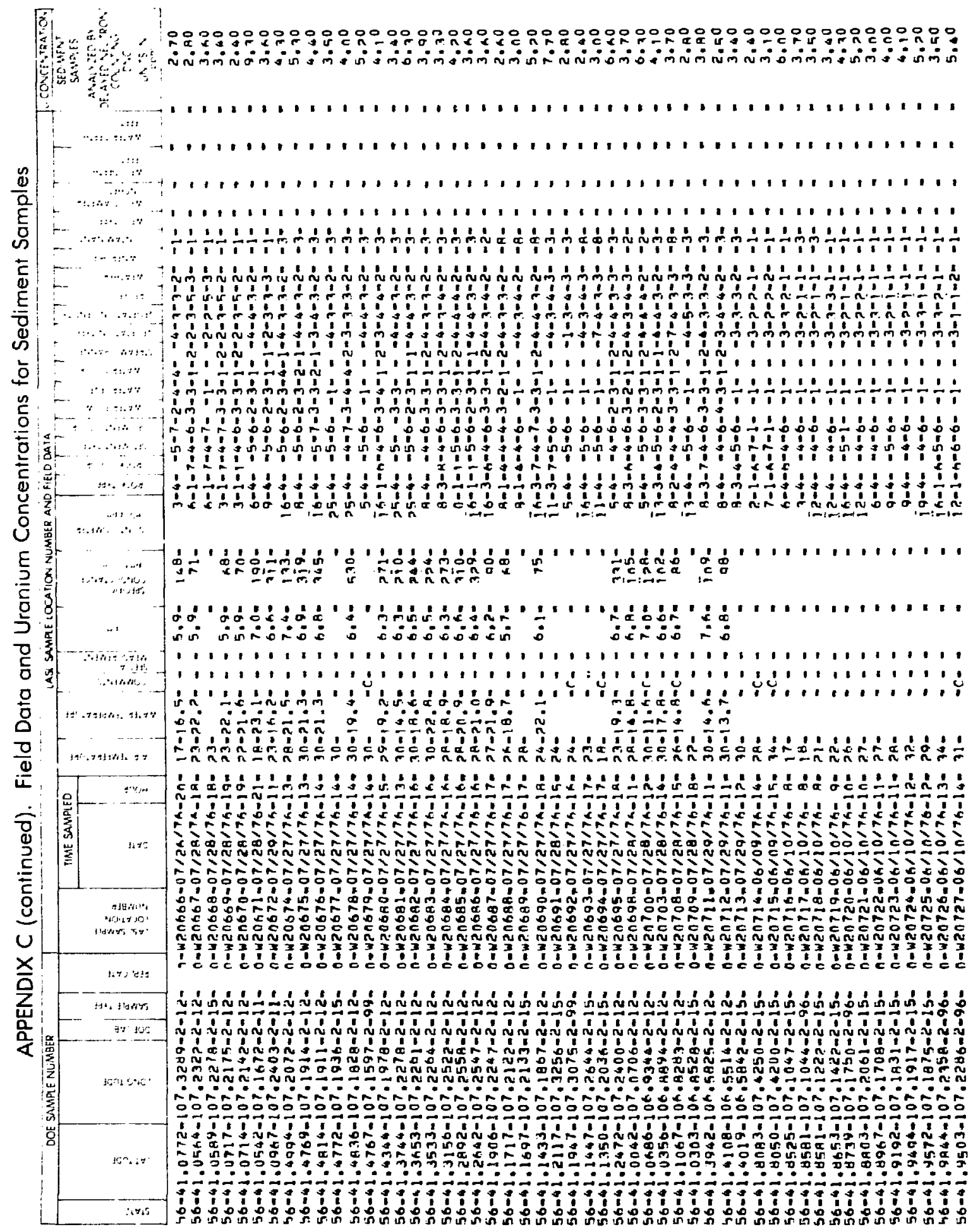




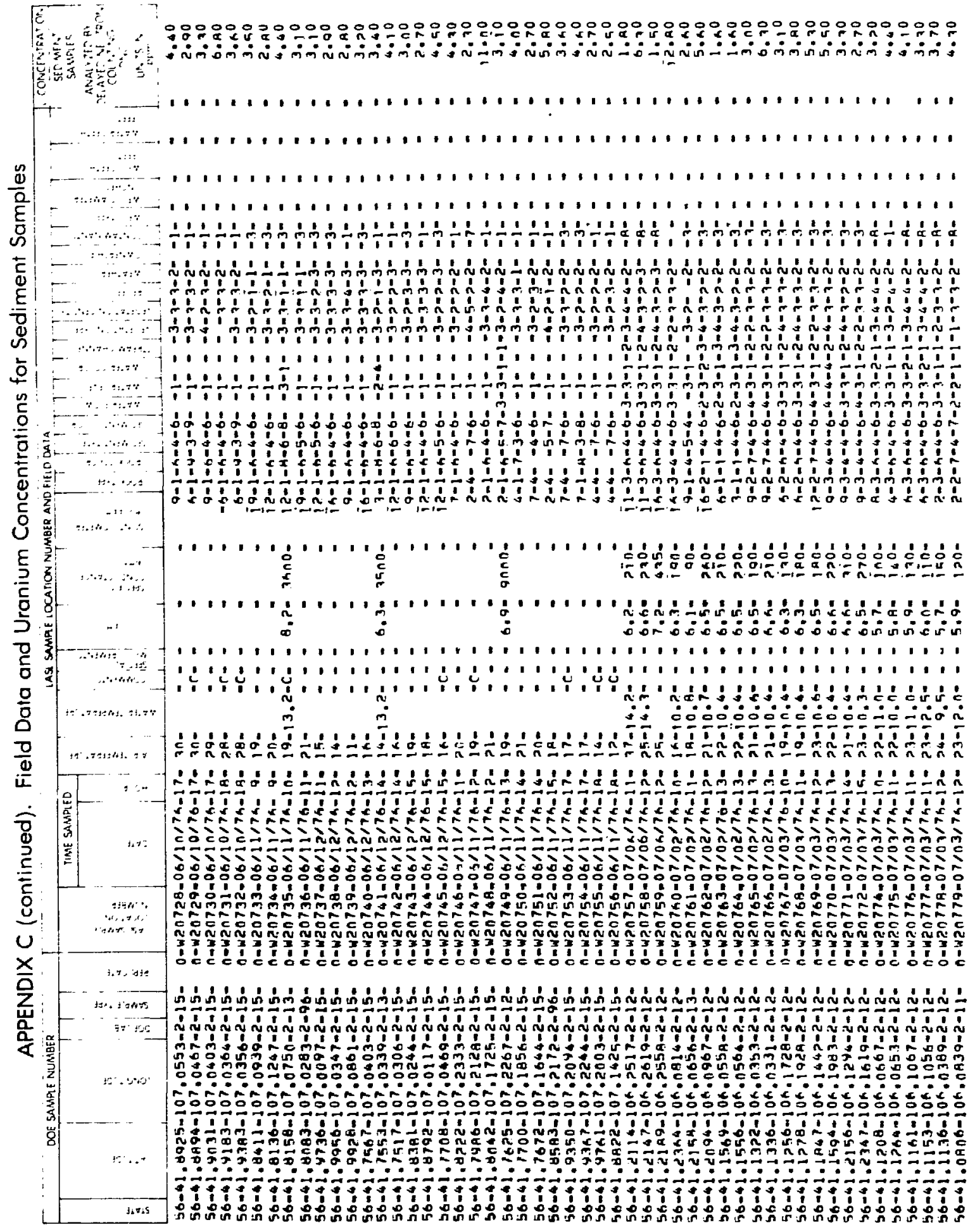




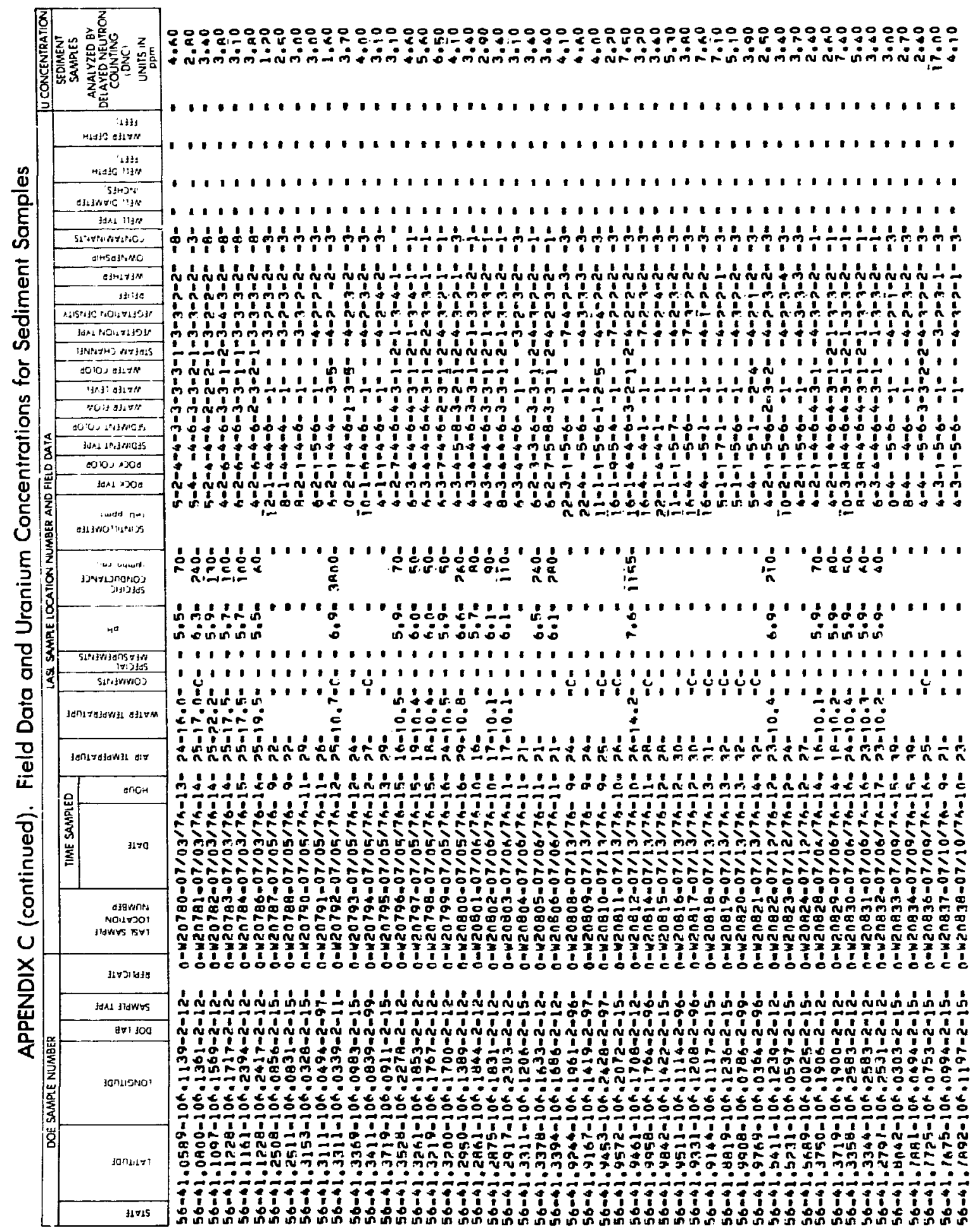




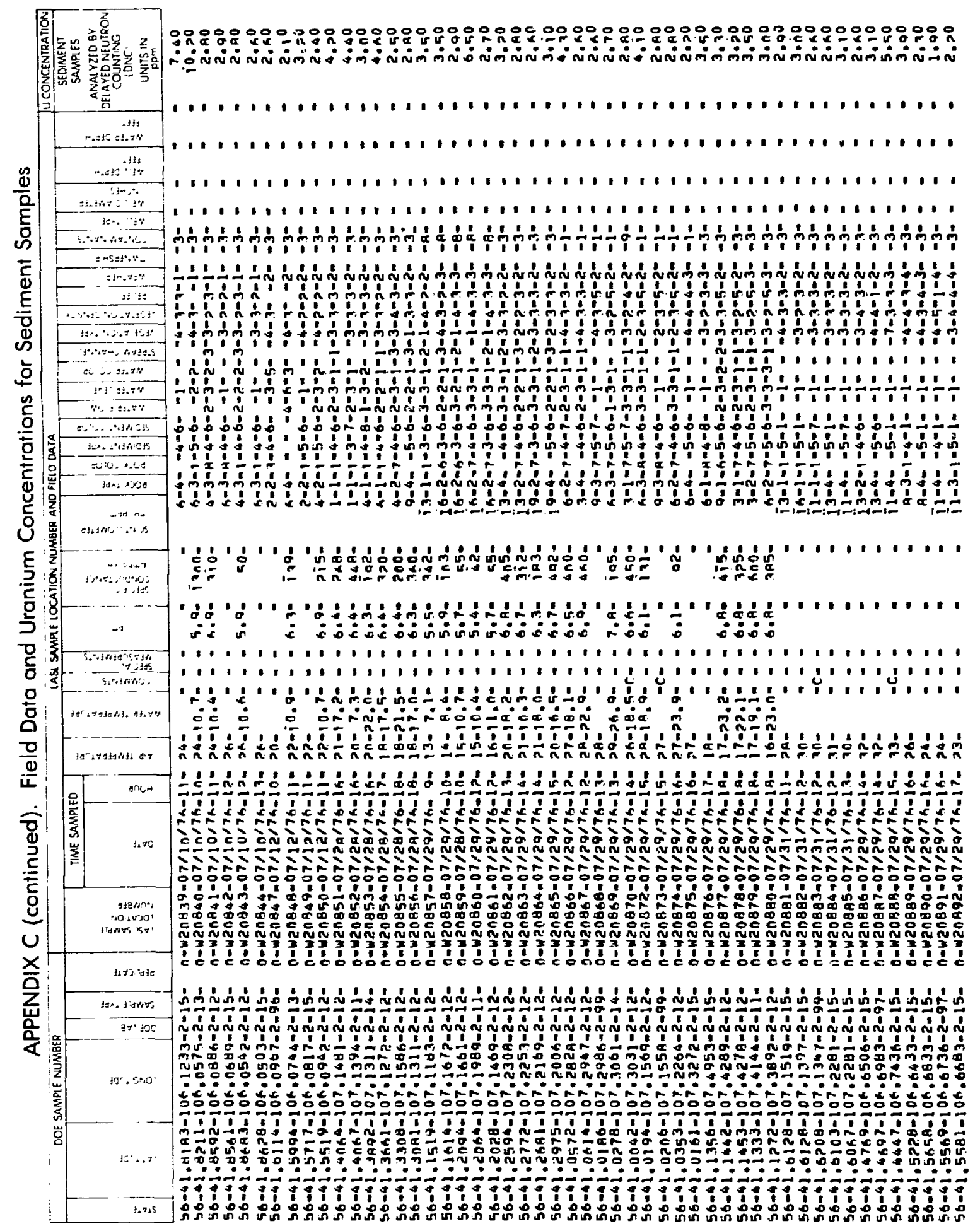




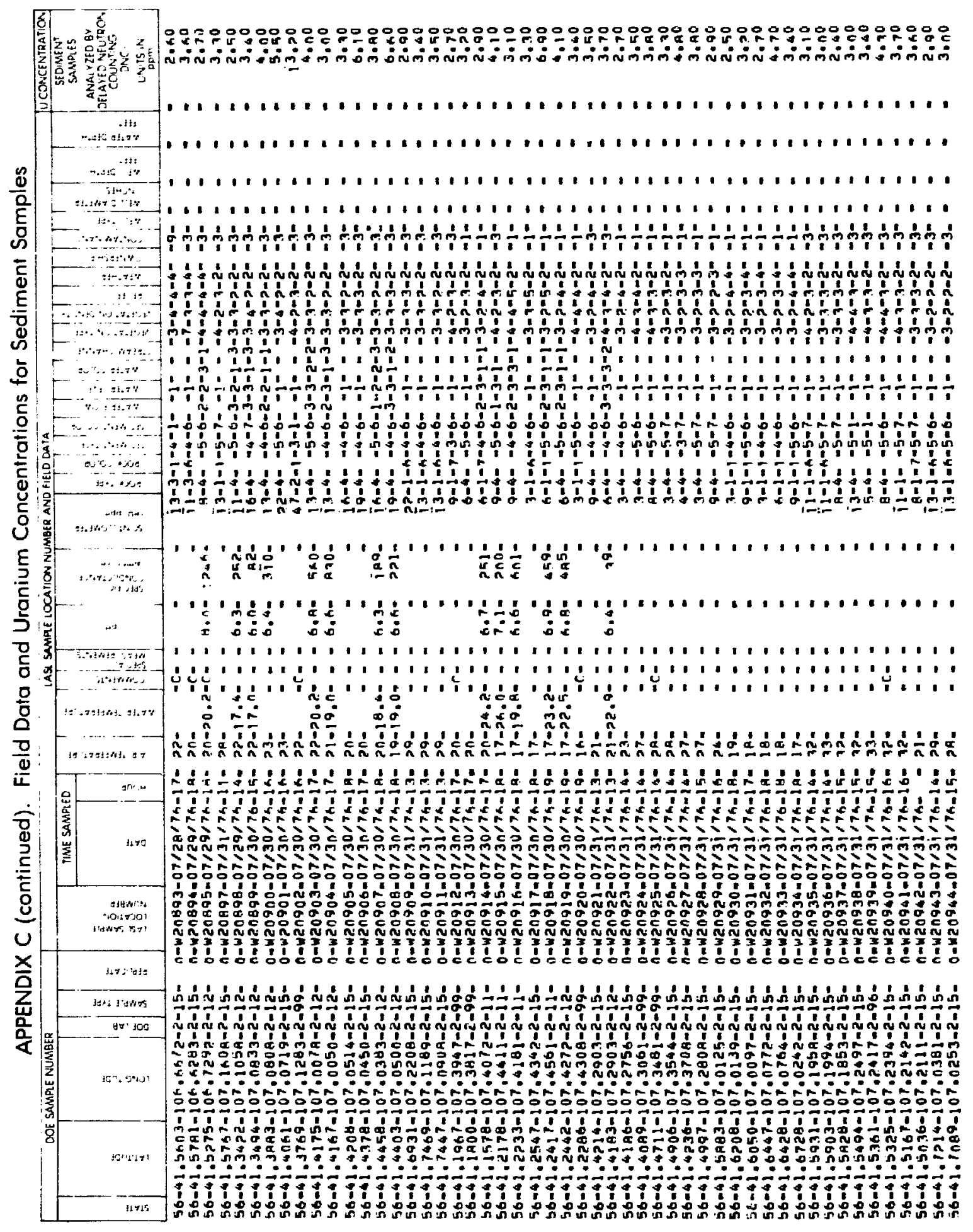




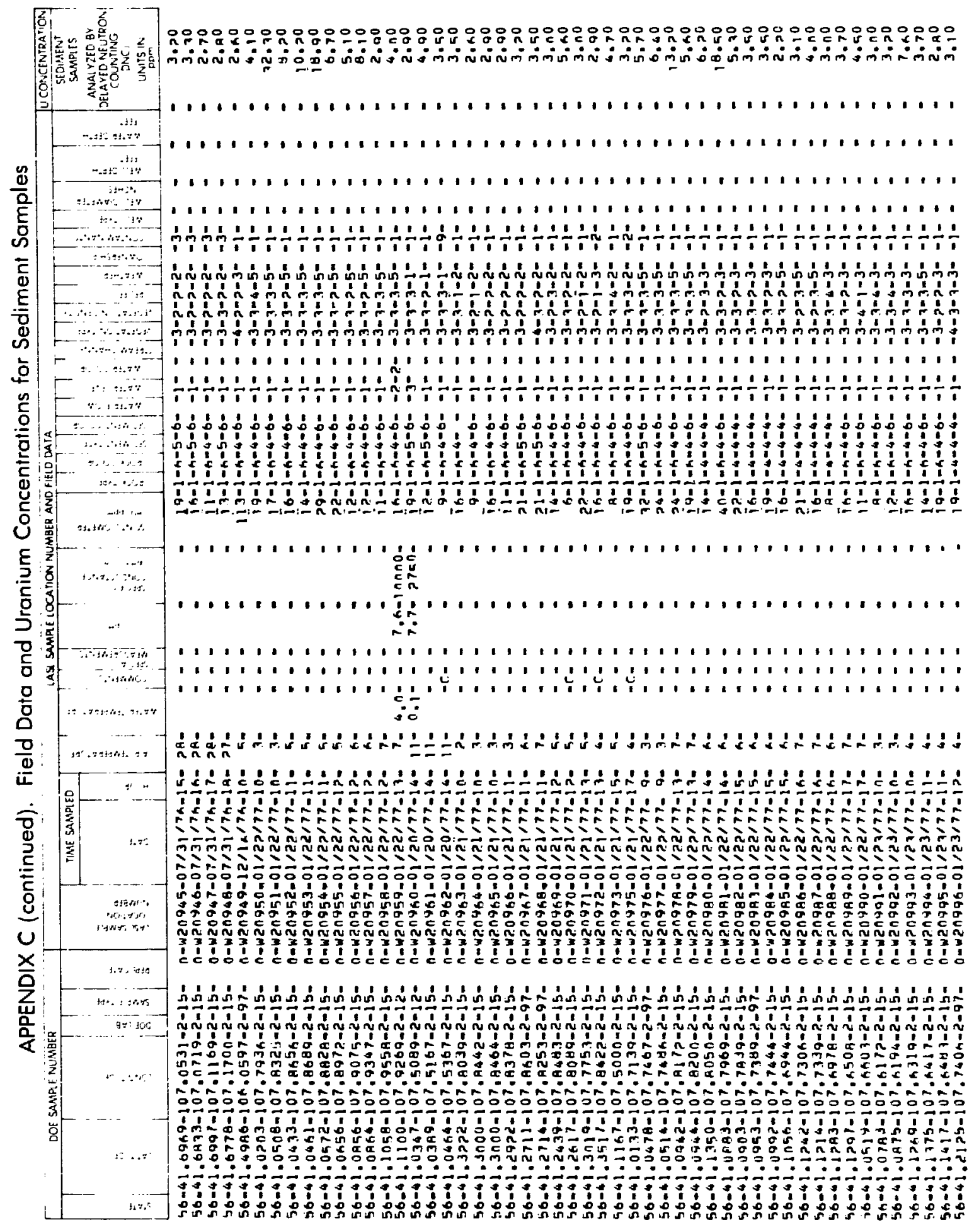




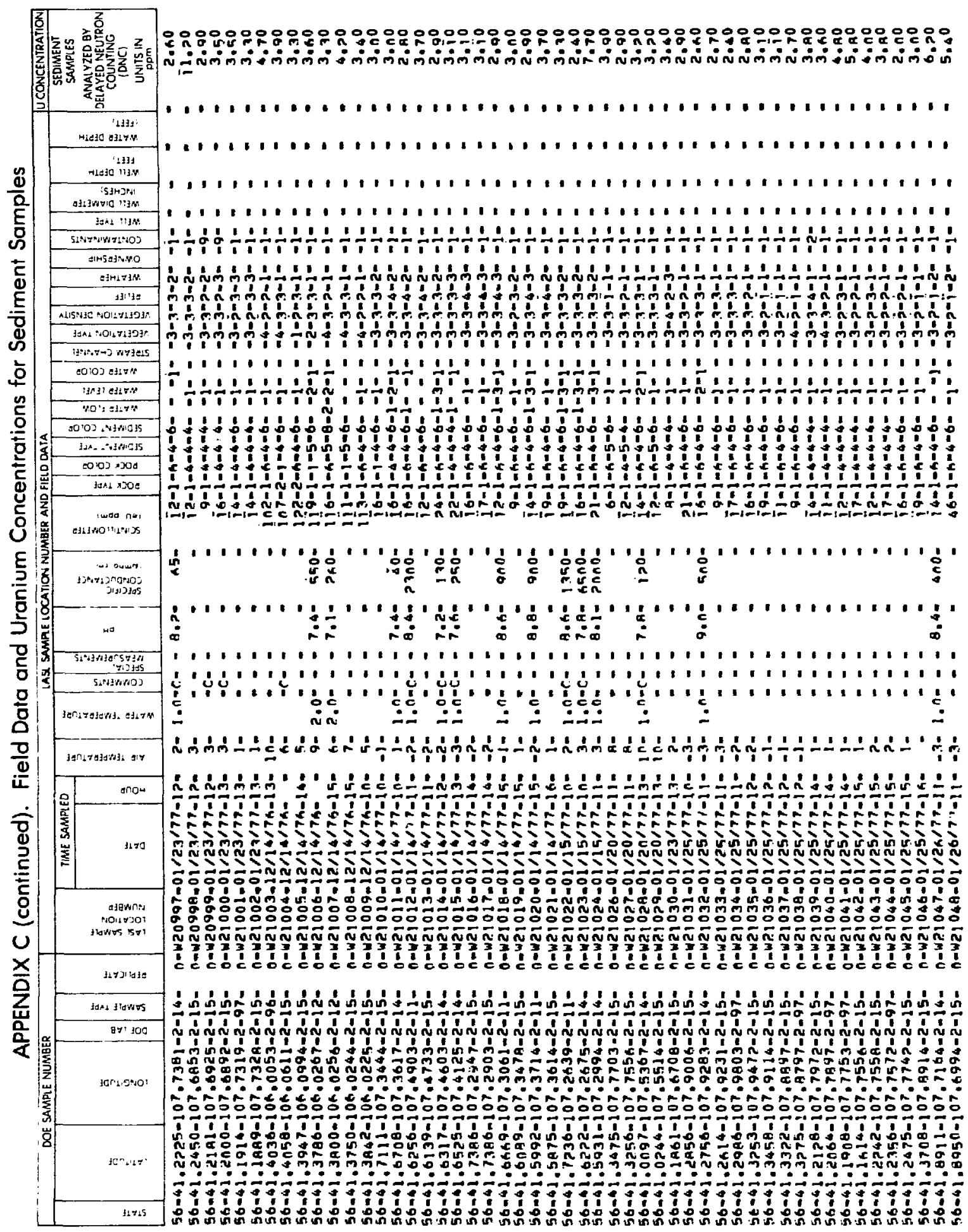




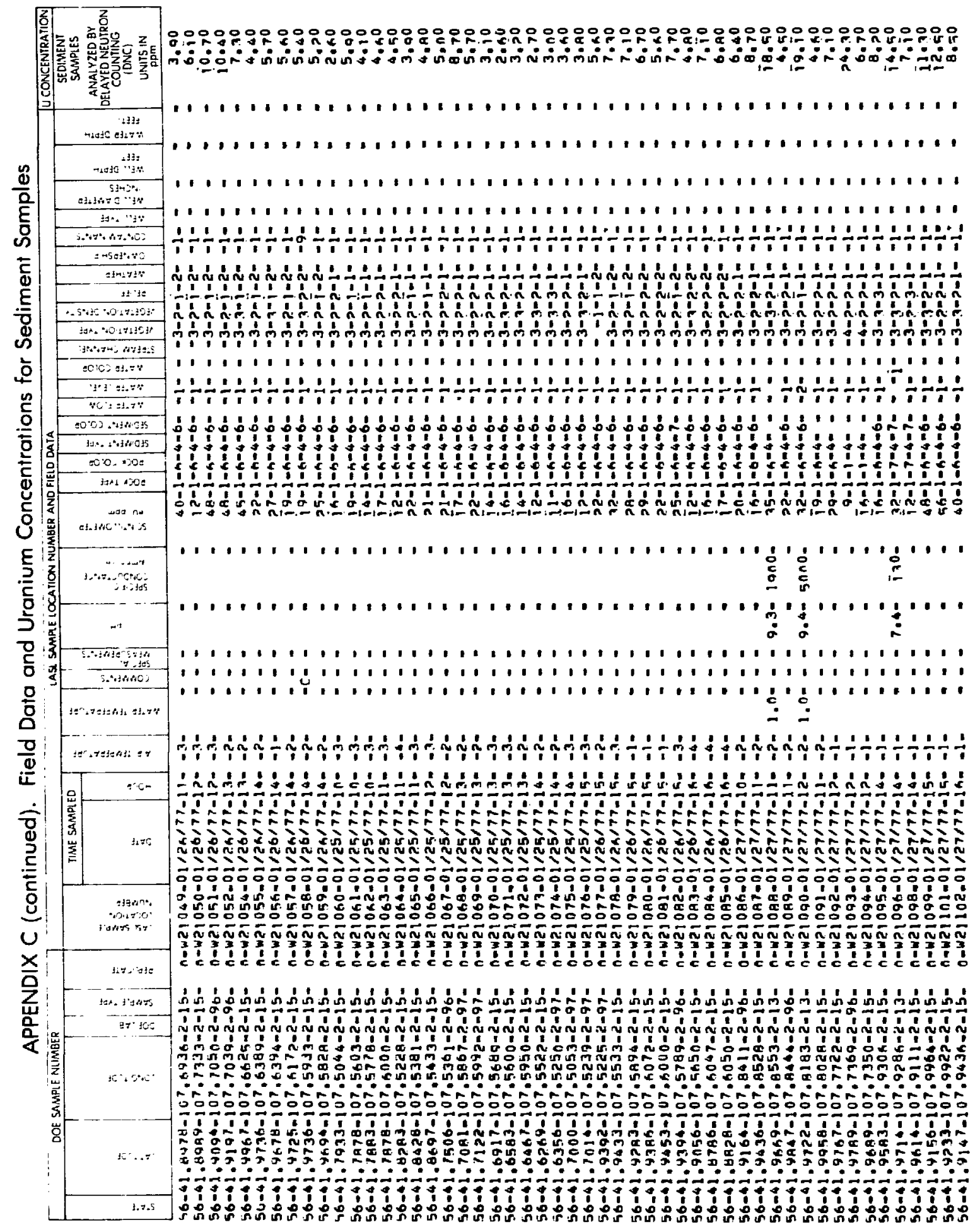




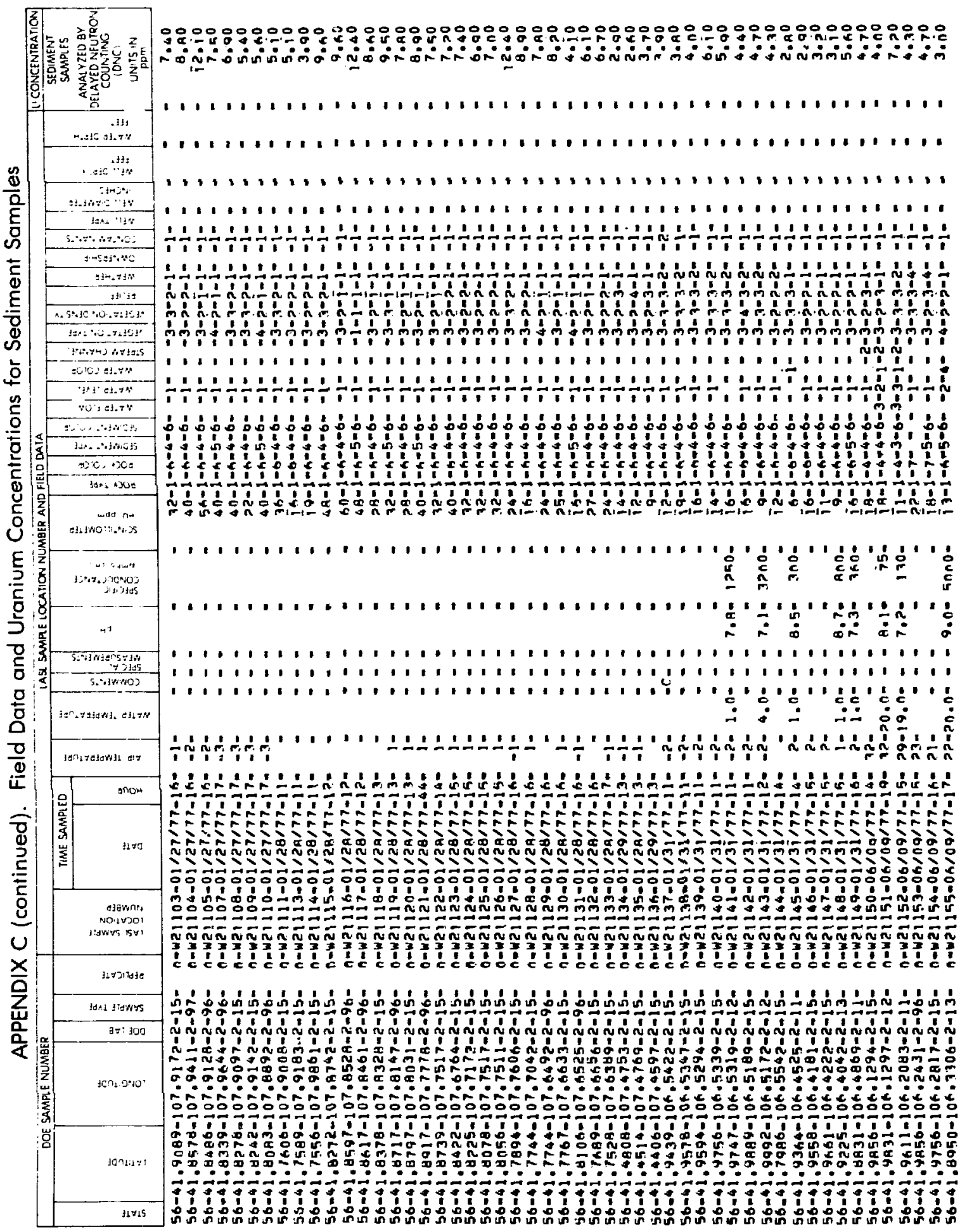




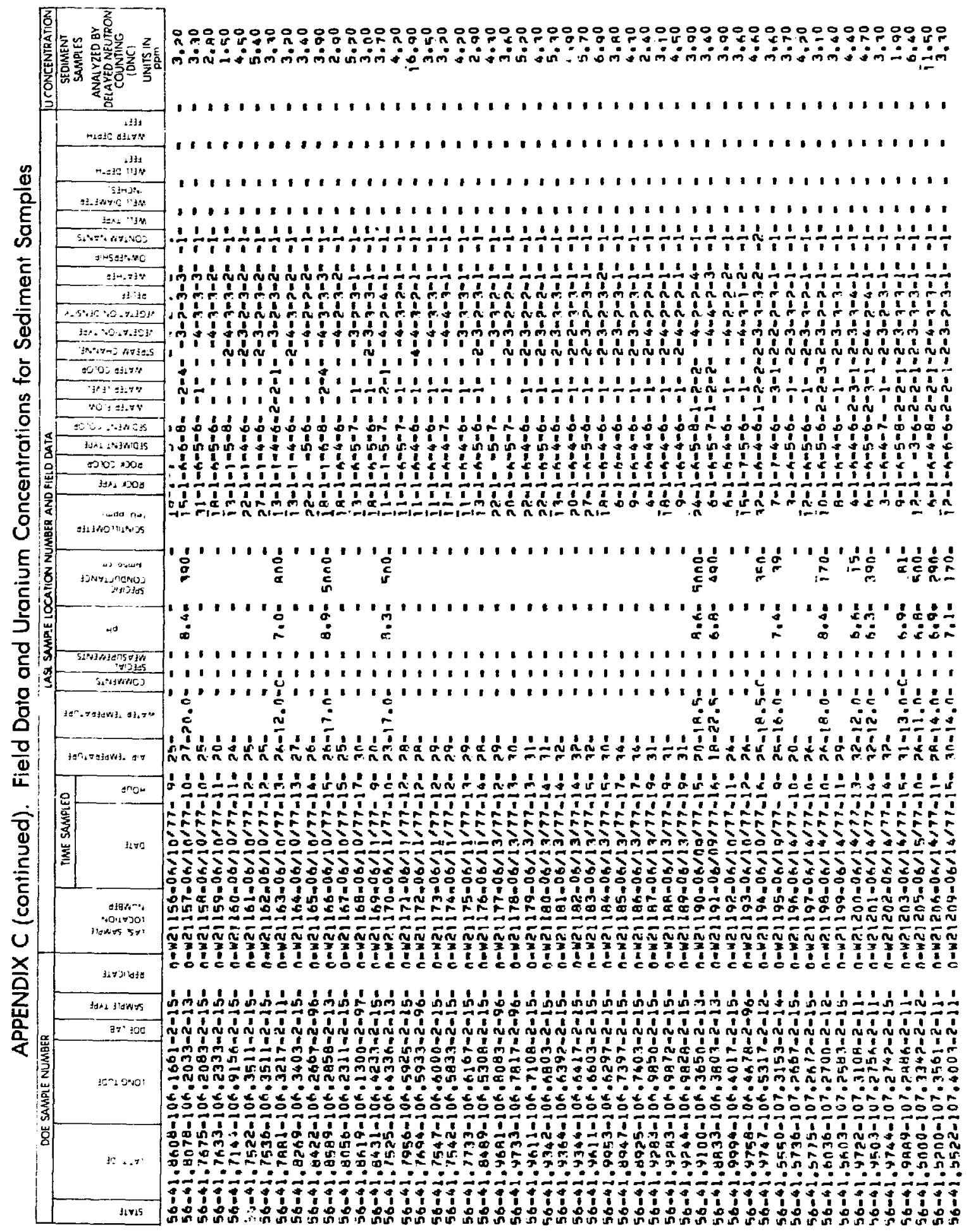




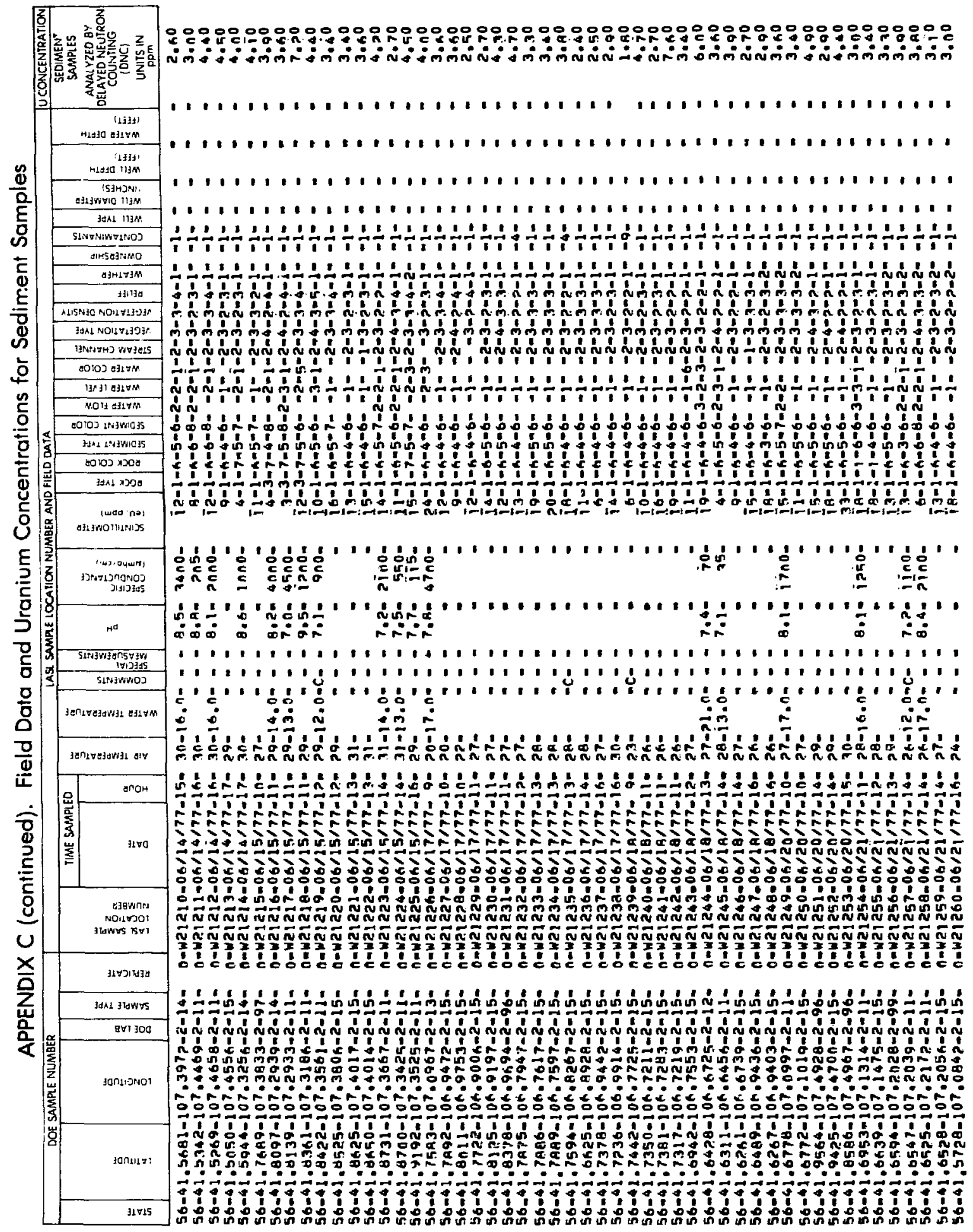




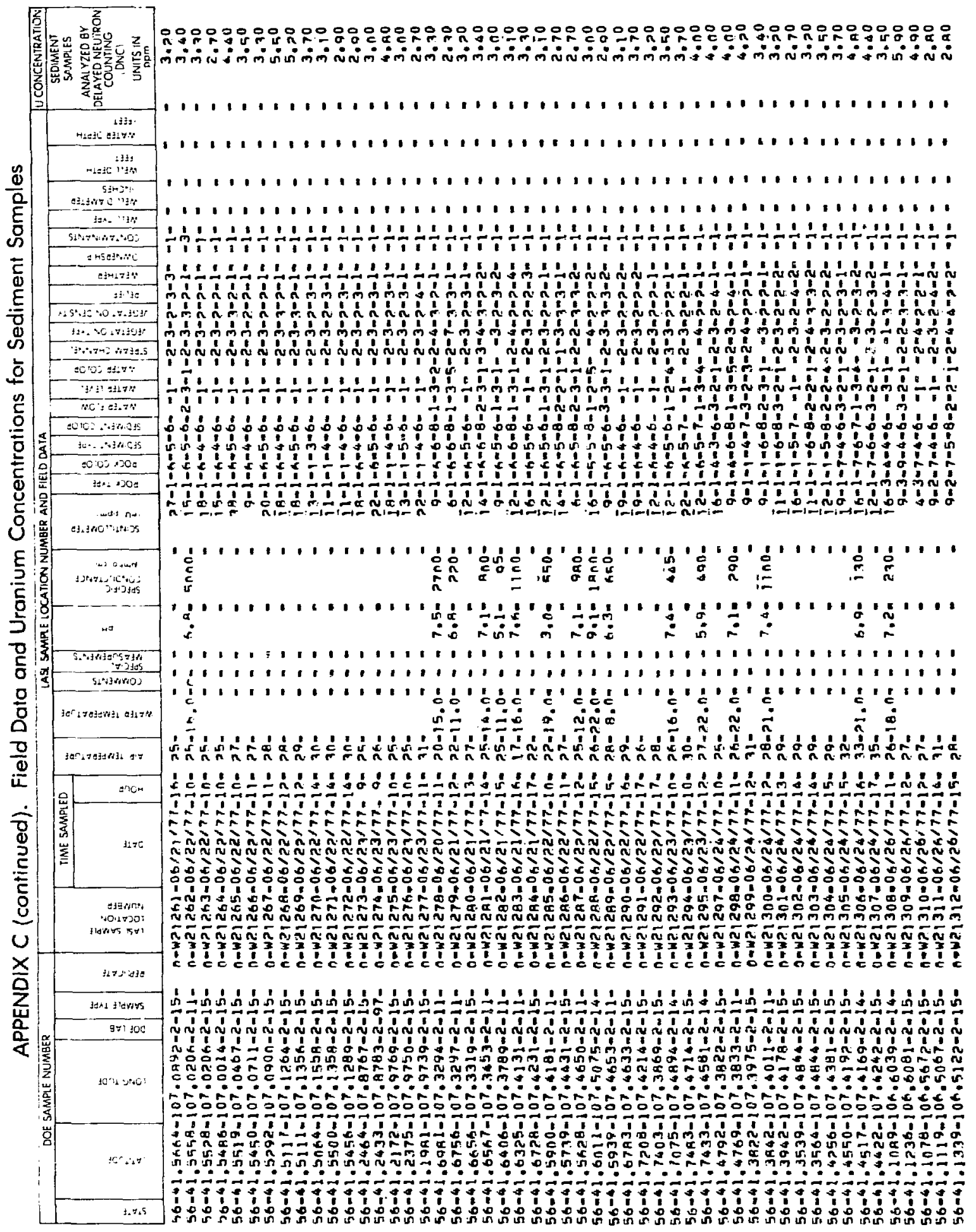




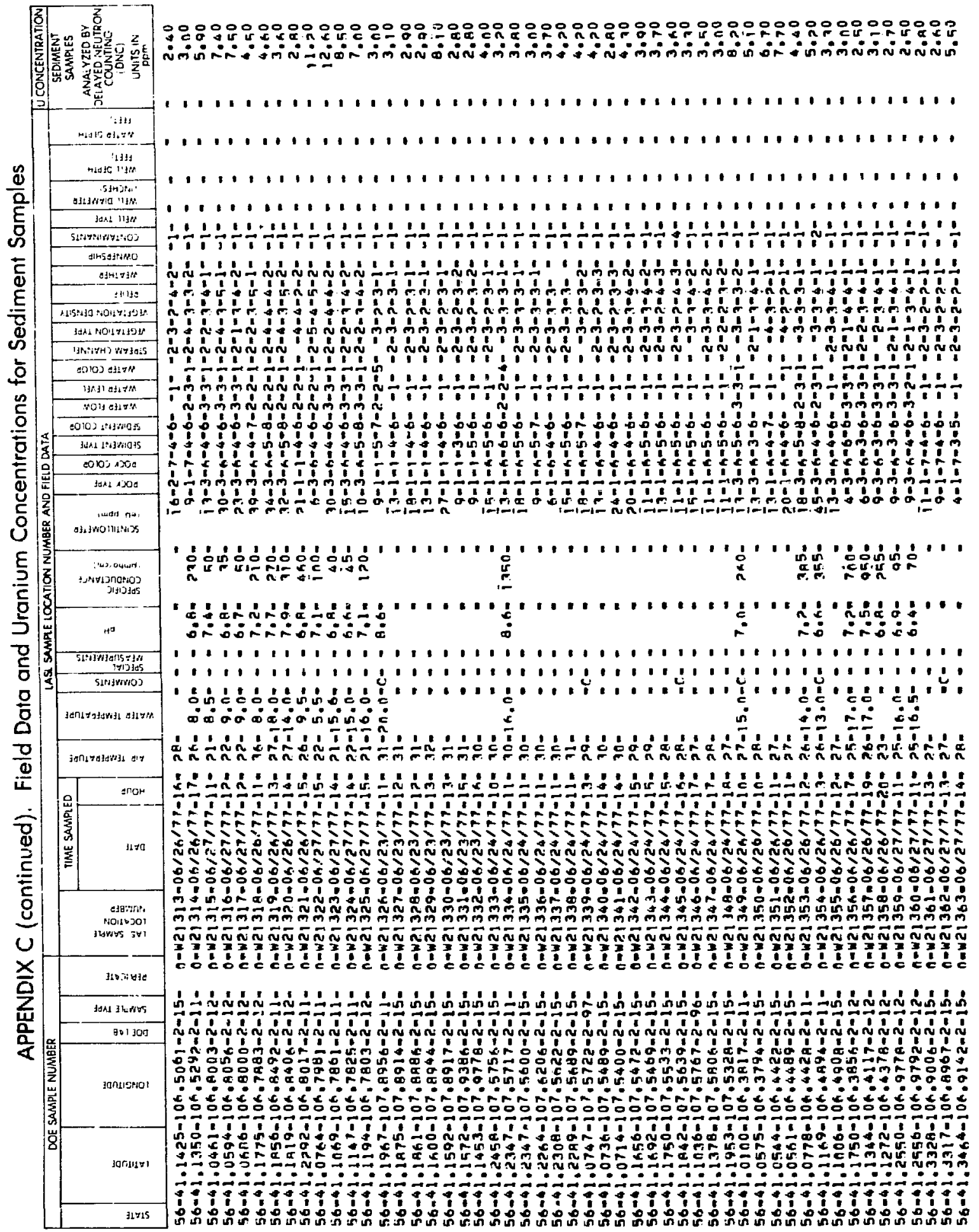


APPENDIX C (continued). Field Dala and Uranium Concentrations for Sediment Samples

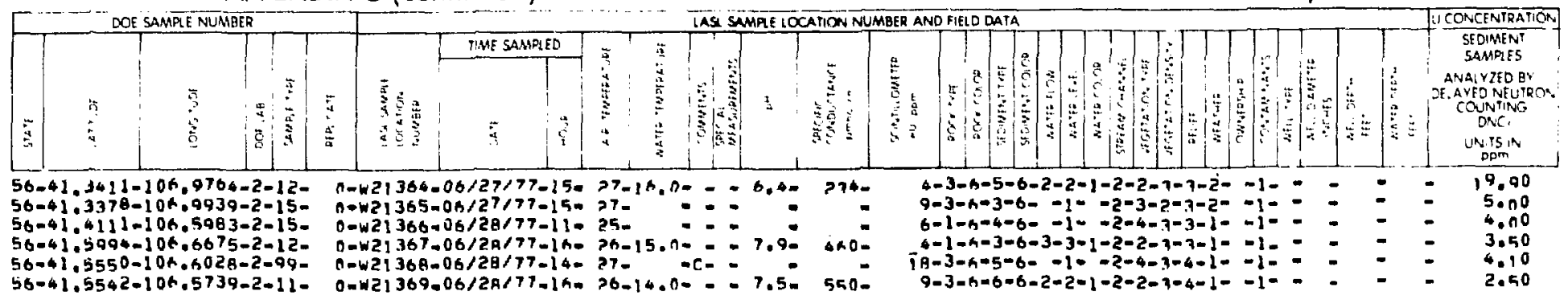


APPENDIX D

CODE TO DATA LISTINGS

APPENDIX D-I

Explanation of Codes Used

APPENDIX D-II

Key to Sample Types 


\section{APPENDIX D-I}

EXPLANATION OF CODES USED

\section{DOE SAMPLE NUMBER}

STATE: A two-digit Federal Tnformation Processing Standards (FIPS) code, designating the state from which each sample came. For the states heing covered by the LASL, the code numbers are:

Alaska $=02$
Arizona $=04$
Colorado $=08$
Idaho $=15$

$\begin{array}{ll}\text { Montana } & =30 \\ \text { New Mexiao } & =35 \\ \text { Oklahoma } & =40\end{array}$

$\begin{array}{ll}\text { Texas } & =43 \\ \text { Utah } & =49 \\ \text { Wyoming } & =56\end{array}$

LATITUDE AND LONGITUDE: Samplo location, in degrees and decimal degrees to four places. Although generally much better, locational accuracy cannot be guaranteed closer than about $300 \mathrm{~m}$ (1.000 ft).

DOE LAB: A Department of Energy (DOE) one-digit identifier designating the DOE laboratory responsible for taking the samples and data shown in the listings, as woll as providing the analyses of the uranium and other elementa concentrations, if any. The LASL is designated by the numeral ?.

SAMPLE TYPE: A two-digit identifier which specifically designates the pertinent properties defining the sample type to which the listed data relate. For explanation of the code used, refer to the attached "Key to Sample Types," Appendix D-II.

REPLICATE: A three-digit sequential number assigned to indicate a multiple sample of a single sample type from a single location. The largest number in use iadicates the most recent sample taken, and there will always be smaller sequential numbers representing earlier samples back to 000, which is the initial sample from any given location. Except in the case of special studies, there will be no replicate samples and this entry will therefore be 000 .

\section{LASL SAMPLE LOCATION NUMBER AND FIELD DATA}

LASL SAMPLE LOCATION NUMBER: A unique six-plano alphanumeric designator permanently assigned by the LASL to every location ampled. For internal use these numbers are assigned in blocks to the various areas individually treate and reported upon, and therefore serve to generally locate the samples within various areas for which the LASI, is responsible as follows.

Location Numbers

N00 001 tirirough N99 999

C00 001 through C99 999

W00 ool through w99 999

Y00 001 through M99 999

$A D 0$ 001 and above

LOO 001 and above

000001 and above

\section{State}

= Principally New Mexico

$=$ Principally Colorado

$=$ Principally Wyoming

= Principally Montana

= Alaska only

$=$ Areas beyond the western boundary of LASL's region as established by DOF in 1977 .

$=$ Areas heyond the eastern boundary of LASL's region as established by DOE in 1977 . 
TIME SAMPLED: The DATE that the sample was taken, in terms of the number of the MONTH, followed by the DAY and finally the YFAR, separated by slashes, and then the TIME it was taken on that date to the nearest whole HOUR on a 24-hour clock.

AIR TEMPERATURE: The temperature that was measured in the shade at the time of sampling, to the nearest whole degree Celsius $\left({ }^{\circ} \mathrm{C}\right)$.

WATER TEMPERATURE: The temperature that was neasured in the sample water (in situ whenever possible) at the time of sampling, to tise nearest one-tenth of a degree Celsius (J. $2^{\circ}$ ).

COMMENTS: A "C" in this column indicates that some secondary comment not included in the listing was recorded at the sample location. This information will be used by the LASL in evaidating the data, and if appropriate, it will be mentioned in the final report.

SPECIAL MEASUREMENTS: An "S" in this columa indicates that one or more rielt measurements in addition to those listed were made at tine sample location. A description of any special parameters measured and the measured value at each sample location will be included in the final HSSR survey report on the area.

$\mathrm{pH}$ : The $\mathrm{pH}$, to the nearest one-tenth $(0.2)$ of a $\mathrm{pH}$ unit, that was neasured in the water at the sample location at the time of sampling.

SPECIFIC CONDUCTANCE: The conduetivity, in $\mu$ mo/cm, that was measured in the water at the sample location at the time of sampling. Conductivities which exceed the range of the meter (i.e., >50 000 llmhos/ $\mathrm{m}$ ) are denoted by 50001 in Appentixes $B$ and $C$.

SCINTILLOMETER: The equivalent uranium (eU), in ppm, as measured on a flat ground surface within $10 \mathrm{~m}$ of the sample location using a scintillometer fitted with a differential gamma sampler (DGS). The effect of the DGS is to introduce a fixed geometry into the measurement and remove the background.

ROCK TYPE: The single digit in this column provides a general description of the dominant lithologic regime at or near the sample location, as given below.

$$
\begin{array}{ll}
1=\text { Sedimentary } & 3=\text { Igneous } \\
2=\text { Metamorphic } & 4=\text { Unknowi }
\end{array}
$$

ROCK COLOR: The single digit in this column provides an indication of the observed dominant color of local bedrock exposures at or near the sample location, as given below.
$\mathrm{l}=$ White/Buff
$4=$ Pink/Red
$2=$ Yellow
5 = Green
$7=$ Gray
3 = Orange
$6=$ Brown
$8=$ Black
$9=$ Other

SEDIMENT TYPE: The single digit in this column provides a subjective evaluation of the dominant sediment type at the sample location, as given below.
$1=$ Boulders
$4=$ Sand
$7=$ other
2 = Cobbles
$5=$ Mud
$3=$ Gravel
$6=$ Muck 
SEDIMENT COLOR: The stingle digit in this column indicates the observed dominant color of the bottom sediment (stream channel, lake bed, etc.) at the sample location at the time of sampling, as given below.
1 = White/Buff
4 = Pink/Red
$7=$ Gray
$2=$ Yellow
$5=$ Green
$8=$ Black
$3=$ Orange
$5=$ Brown
9 = Other

WATER FLOW: The single digit in this column provides a subjective evaluation of the water movement at the sample location at the time of sampling, as given below.
$l=$ Stagnant
$2=$ Slow
$3=$ Moderate
$5=$ Torrent
4 = rast

WATER LEVEL: The single digit in this column provides a subjective estimate of water quantity at the time of sampling, relative to its usual condition at the sample location, as given below.
$1=$ Dry
$3=$ Normal
5 Flood
2 = Low
4 = High

WATER COLOR: The single digit in this column provides a subjective evaluation of suspended load in the sample water- as, given below.
1 = Clear
$3=$ Cloudy
$5=$ A.lga.l
2 = Murky
$4=$ Muddy
$6=$ Other

STREAM CHANNEL: The single digit here gives a subjective evaluation of stream channel character at the sample location at the time of sampling, as given below.
1 = Depositing
2 = Eroding
$3=$ Unknown

VEGETATION TYPE: The single digit in this column provides a subjective evaluation of the dominant plant type in the visinity of the sample location, as given below.
$1=$ Conifers
$4=$ Grass
$7=$ Other
$2=$ Deciduous
$5=$ Moss
$3=$ Brush
$6=$ Marsh

VEGETATION DENSITY: The single digit in this column provides a subjective estimate of the amount of plant cover in the vicinity of the sample location, as given below.
1 = Barren
$3=$ Moderate
$5=$ Very Dense
2 = Sparse
4 = Dense

RELIEF: The single digit in this column provides a subjective evalustion of the topography within a few hundred meters of the sample location, as given below.

$$
\begin{aligned}
& l=\text { Flat } \\
& 2=\text { Low }(<15 \mathrm{~m})
\end{aligned}
$$$$
3=\text { Gentle }(15-60 \mathrm{~m})
$$$$
4=\text { Moderate }(50-300 \mathrm{~m}) \quad 5=\text { Other }
$$ 
WEATHER: The single digit in this column gives the observed climatic condition at the sample location at the time of sampling, as given below.
$1=$ Clear
$3=$ Dvercast
$5=$ Sno'sy
2 = Partly sloudy
$4=$ Rainy
$5=$ Dther

OWNERSHIP: When shown, the single digit here gives a broad alassification of administrative responsibility or general ownership of the land at the sample location, as given below.
$l=$ Federal
$3=$ Private
$5=$ Dther
2 = State
4 = Indian

CONTAMINANTS: The single digit here indicates known or suspected local factors tikely to influence analytical results, as given below.
$1=$ None
4 = Industry
$7=$ Urban
$2=$ Mining
$5=$ Sewage
$3=$ Recreation
3 = Agriculture
5 = Power generation
$9=$ Other

WELL TYPE: If a well water sample, the single digit, in this column provides a general description of the type of well from which the sample was taken as given bolow.

$\begin{array}{lll}1=\text { Windmill-stock } & 4=\text { Suction pump } & 7=\text { Hand bail } \\ 2=\text { Windmill-domestic } & 5=\text { Jet pump } & 9=\text { Unknown } \\ 3=\text { Submersible pump } & 5=\text { Large turbine } & 9=\text { Other }\end{array}$

WELL DIAMETER: When shown, the one or two digits in this column give the measured or estimated inside diameter, in inches, of the well casing from which the water sample came.

WELL DEPTH: When shown, the one, two, or three digits in this column give the totai drilled depth from the surface, in feet, of the well from which the sample came. Three $9 \mathrm{~s}$ in this solumn iadicates a well depth greater than $1000 \mathrm{ft}$.

WATER DEPTH: When shown, the one, two, or three digits in this column give the known depth, in feet, from the surface to the standing water in the well. A -1 in this column indicates a flowing artesian well.

URANIUM CONCENTRATION: The value given in tiis column is the analytically derived value of the total uranium concentration found in the water sample in $\mathrm{ppb}$, or in the sediment sample in ppm. Those uranium concentrations in water that are shown with an asterisk were measured using a delayed-neutron counting method, while those witiout an asterisk were determined fluorometrically. The uranium analyses as determined by both of these methods at the LASL are directly comparable, as described in Appendix A. 


\section{KEY TO SAMPLE TYPES}

This numerical key provides the necessary tie between the specific type or form of each sample taiken and each individuzl suite of iield and laborztory data to which the sample relates. It defines the various sample types collected by the LASL in the DOE HSSR for uranium.

The two-digit key number assigned to each sample type designates three distinct properties of the samples taken. These properties are: (a) The general sample source (spring or stream or dry siream, etc.); (b) The sampl: medium (water or sediment, etc.); and (c) The treatment given tiae sample in the field or laboratory pior to its analysis by the LASL.

The key numbers are inserted in the appropriate columns of the speaially formatted DOE sample numbering system to positively identify the sample type for $a ! l$ LAST, sample data submitter.

KEY NO. SOURCE / MEDIUM / TREATMENT

01 - Spring water sample untreated.
02 - Stream water sample untreated.
03 - Well water sample untreated.
04 - Natural pond water sample untreated.
05 - Artificial pond water sample untreated.

05 - Spring water sample filtered through an 0.45- $\mu$ membrane filter and acidified to $a \mathrm{pH}$ of $\leq \mathrm{l}$ with reagent-grade nitric acid ( $\left.\mathrm{NNO}_{3}\right)$.

07 - Stream water sample filtered through an $0.45-\mu$ memorane filter and acidified to a $\mathrm{pH}$ of $\leq \mathrm{l}$ with reagent-grade nitric acid $\left(\mathrm{HNO}_{3}\right)$.

08 - Well water sample filtered through an $0.45-\mu$ membrane filter and acidified to $a \mathrm{pH}$ of $\leq l$ with reagent-grade nitric acid ( $\left.\mathrm{HNO}_{3}\right)$.

09 - Natural pond water sample filtered through an 0.45- membrane filter and acidified to $a \mathrm{pH}$ of si with reagent-grade nitric acid ( $\mathrm{HNO}_{3}$ ).

10 - Artificial pond water sample filtered through an 0.45- $\mu$ membrane filten and acidified to $a \mathrm{pH}$ of $\leq l$ with reagent-grade nitric acid $\left(\mathrm{HNO}_{3}\right)$.

11 - Wet spring sediment sample dried at $\leq 100^{\circ} \mathrm{C}$ and sieved to -100 mesh through stainless steel sieves.

12 - Wet stream sediment sample dried $a t \leq 100^{\circ} \mathrm{C}$ and siever to -100 mesh through stainless steel sieves. 
13 - Wet natural pond sediment sample dried at $=100^{\circ} \mathrm{C}$ and sieved to $=100$ mesh through stainless steel sioves.

14 - Wet artificial pond sediment sample dried at $\leq 100^{\circ} \mathrm{C}$ and sieved to -100 mesh through stainless steel sieves.

15 - Dry stream sediment sample dried at $\leq 100^{\circ} \mathrm{C}$ (if necessary) and sieved to -100 mesh through stainless steel sieves.

95 - Dry natural pond sediment sample dried at $\leq 100^{\circ} \mathrm{C}$ (if nesessary) and sieved to $=100$ mesh through stainless st.eel sieves.

97 - Dry artificial pond sediment sample dried at $\leq 100^{\circ} \mathrm{C}$ (if necessary) and sieved to -100 mesh through stainless steel sieves.

98 - Other water

These key numbers are to be used only for water (98) or

99 - Other sediment sediment (99) samples coming from a special source and/ or given a special treatment not described for any of the types of samples above. When used in the 1 istings published herein, the source and treatment given the samples so designated are described in the text. 


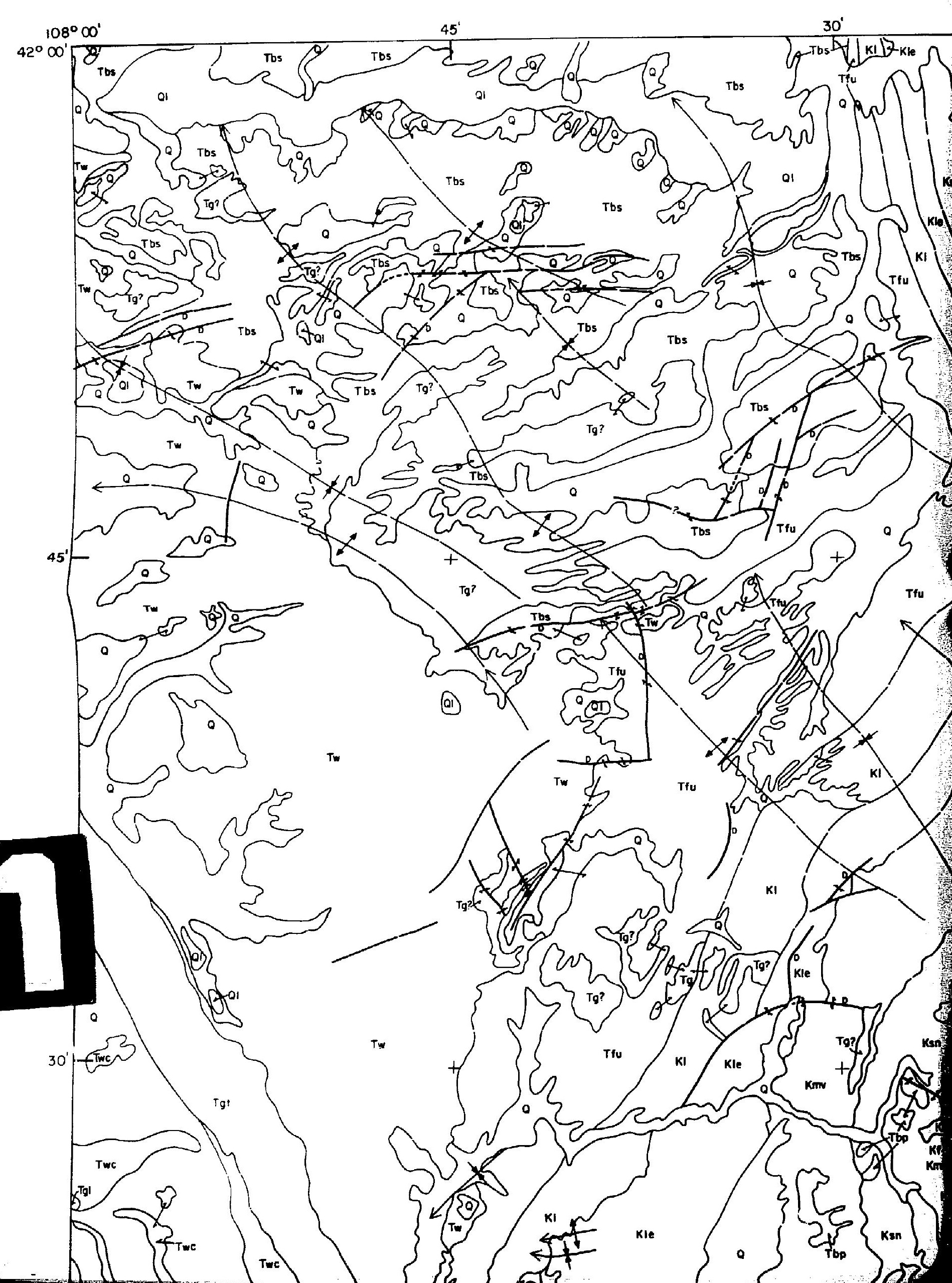




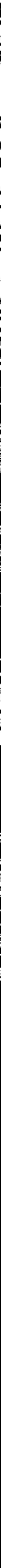

$\mathrm{kmt}$ As

3

$-60+100 \mathrm{~m})(-\mathrm{A}$ h o $62+3 \int^{2}$ ? 


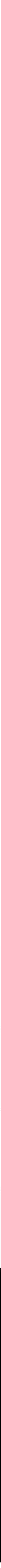




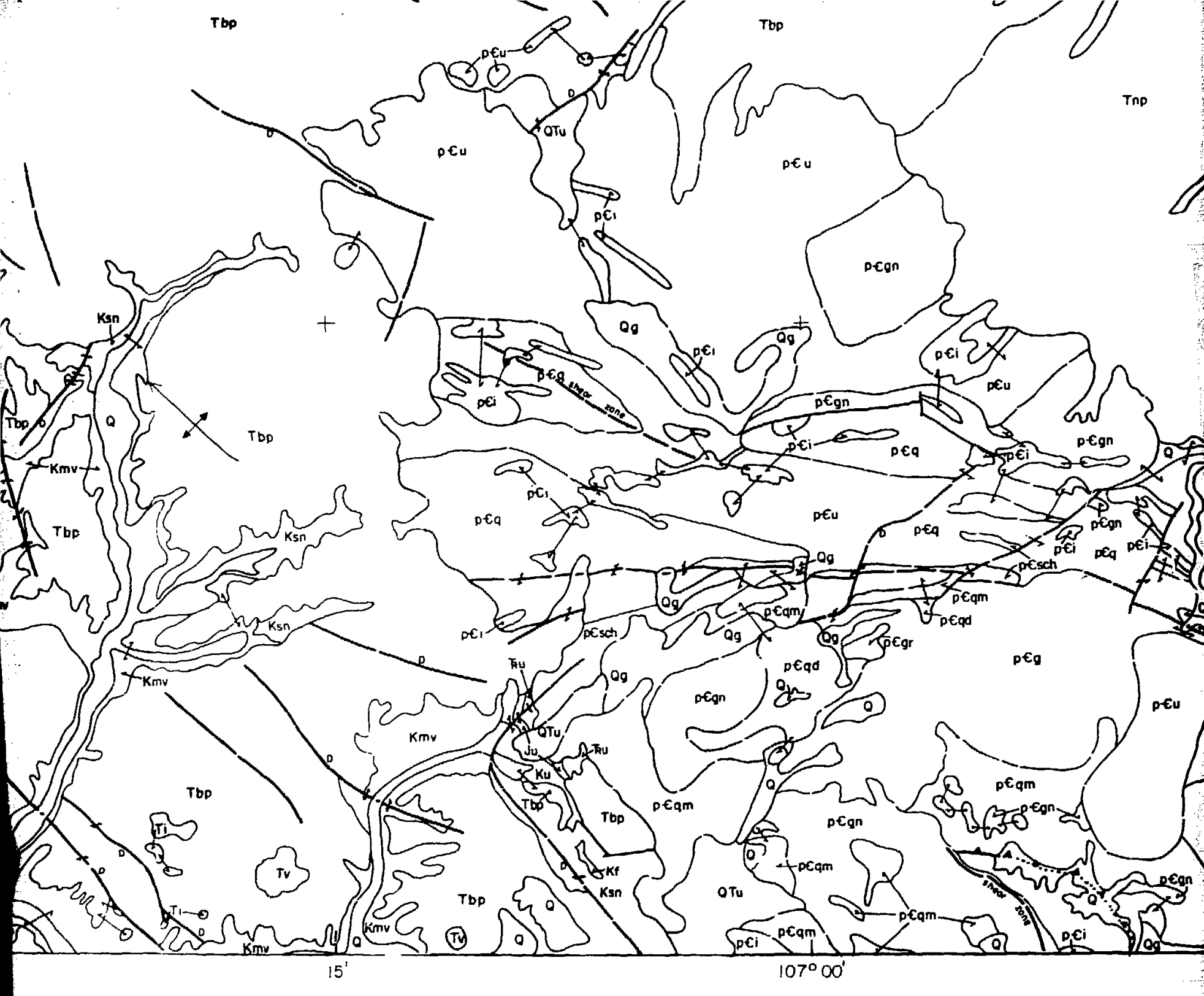

SCALE 1250000

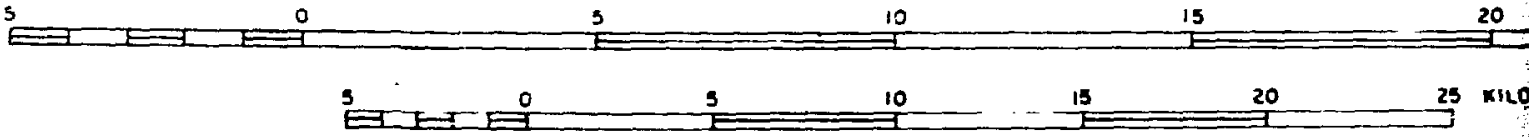

\section{GEOLOGIC MAP OF THE RAWI NTMS QUADRANGLE, WYOMI (After Intrasearch, 1977)}




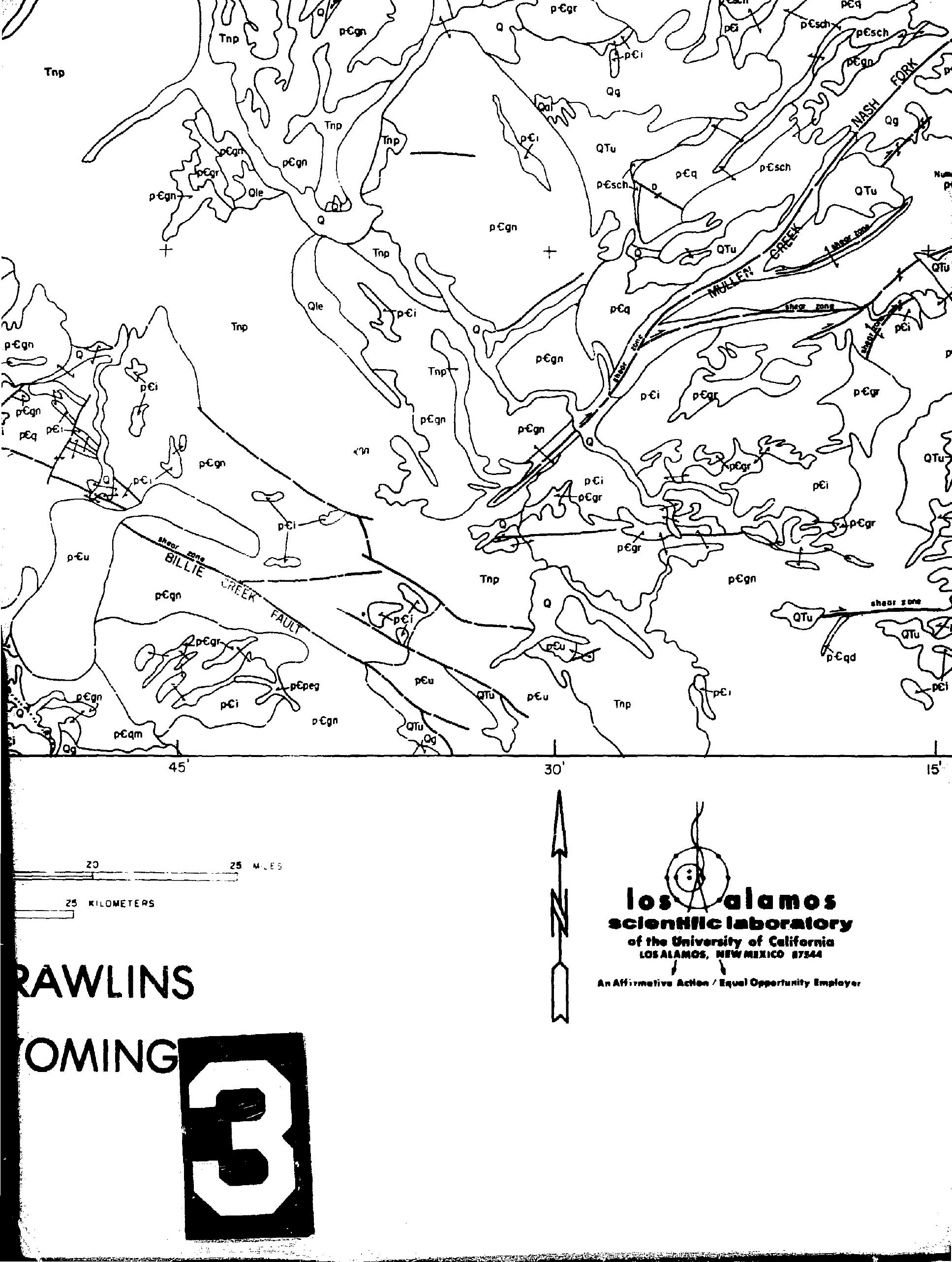




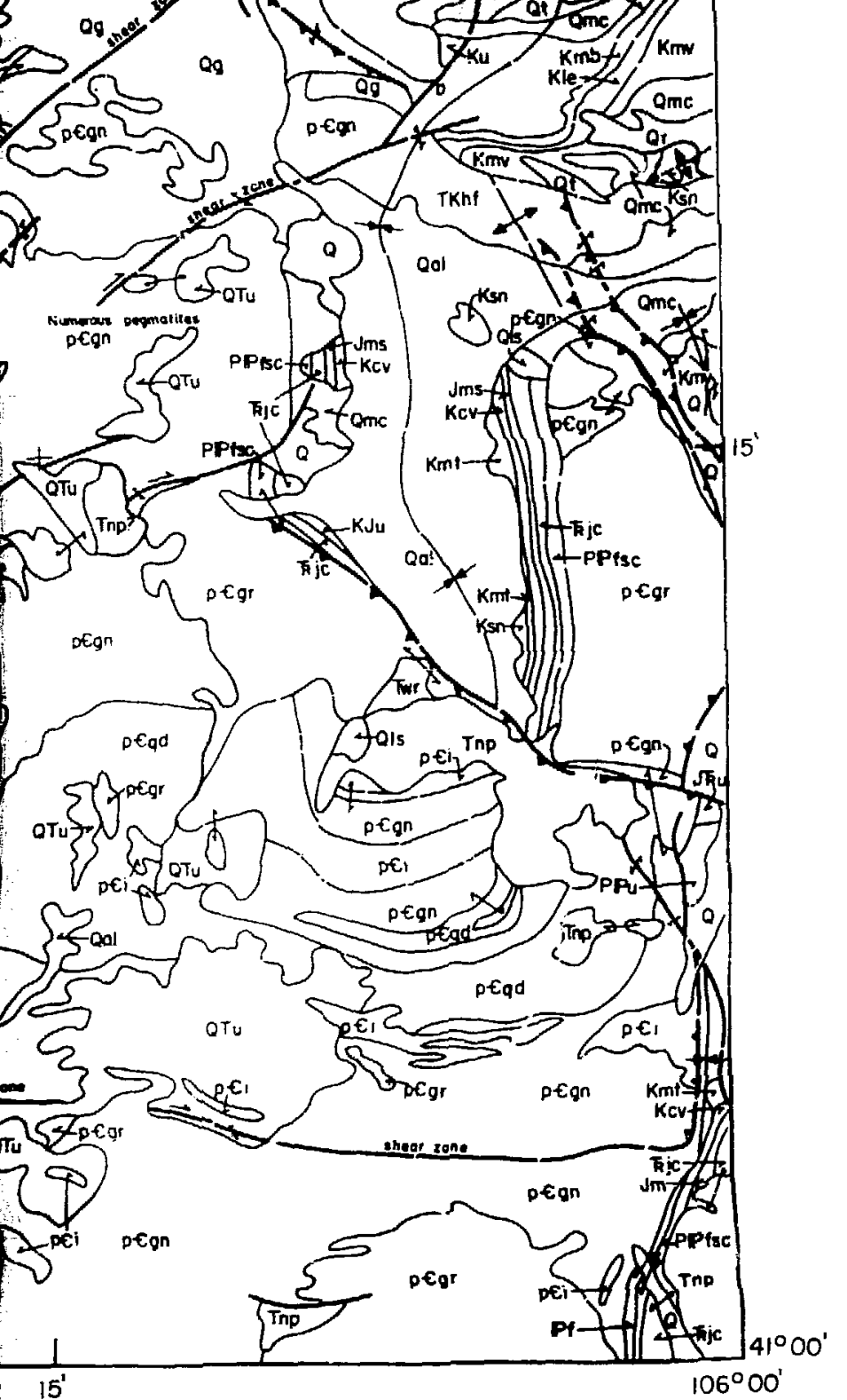

\section{EHIS SHALE}

ardy shalp sliestone and sandstone with lora: weos of codi some iron-stone concretions.

\section{xint}

\section{MESAYERDE GRDUP}

Sray to white, cross-bedded sandstone inter. Dedded cali. shate and siltestone.

\section{Ime \\ MANCOS SHALE}

Dark gray-black shate local sandstone and fossiliferous If fmestones.

\section{STELE SHAL}

Gray to dark-gray shale with thick units of fine-gratned sandstone at top.

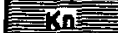

NIOBRAPA FOARATIO

Gray shale at base, overlain by gray silty limestone and gray shale.

\section{FROKTIER FORATTION}

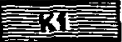

Dark shale with siderite concret ians and

bentonite beds. Hall creek sandstone at tOD.

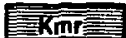 \\ NOWR SHILE \\ Siliceous shale wich bentonite byers,} ilver-gray weathering.

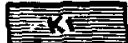

THERHSPOLIS SHALE
Oark shale with thif, brown Sandstone beds. Muddy sandstone member at top.

\section{Fिर}

Daxót Shitostrone

ión to red cross-bedded sandstone and snat

\section{TKev}

CLOVERLY GRLUP

Conglomeratic sandstone at base, pink st.le in middie, ust-colored sandstane at top

$$
\text { 焉 }
$$

MORPTSON FORTATION

Pink, Gurple, and Olue-grey shale, abundane

green thert. White sandstone beds at :OD.

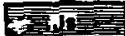

SUMDATCE FOROPATION

Gray and green shales, sandstone irit nolits intest on

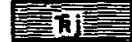 \\ JELA FDPRATIOO}

Drange to red shales and siltestones with cta pebole conqlumerate at base.

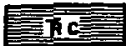

CMIGATER FOB TIO

Red shales, red silitstones, scme then beds nt Itmestone dnd gypsur.

\section{EPPIS \\ FOREILE LIAESTONE}

BIuish-qray compact crenulated 1 imescone.

$$
\text { Ps }
$$

\section{WYOMING}

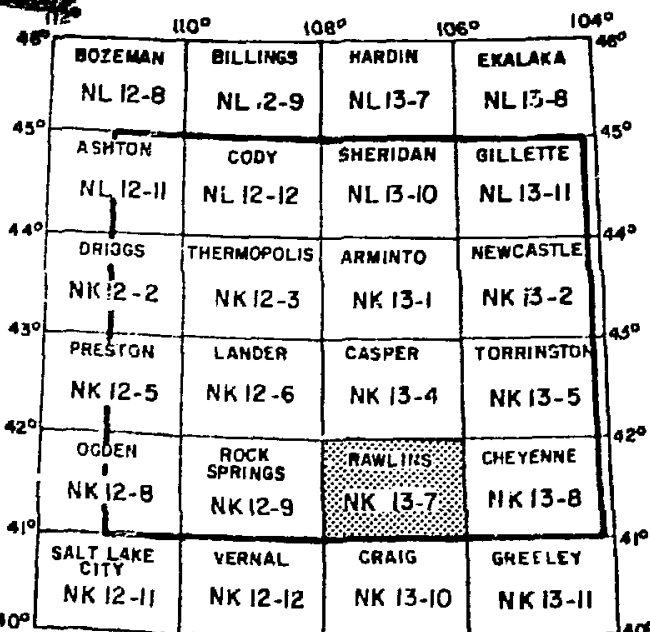

Red shales and siltstones with local beds grpsum.

\section{Po}

GOOSE EGG FORMATION

Red shales, siltstone and beds of 1 imestone and gypsum.

\section{$\mathrm{PPC}$}

CASPER FOEHATOM

White cross-bedsed sandstone with 1 itmestone near 100 .

\section{Pf}

FOUNTAIN FORMATION

Puro', drkns te sandstone, siltstone and shale.

\section{Pre $\mathrm{Pr}$}

TENSLEEP FOASETION

White to buff, cartiy dolonitic sardstane. To light colored porous sandstone.

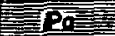

AMSDEN FORMATION

Red shale and limestone sequence with Banuin sandstone nember ot base. 
\begin{tabular}{l} 
Oal \\
\hline Alic \\
Montle le cover \\
Mandslide deposits
\end{tabular} Gravels

terrace deposies

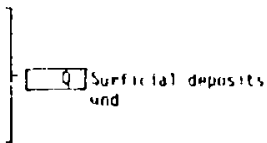

XII.

GHELE SHALE

chale with thick unites of

ane at top.

\section{Th}

- merlatn by gray silt

inimle.

si

Iir Fomation TIt creath sandst one ot top

\section{5}

inisisute mimionite layers. tim.

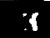

Wals SHLLE

iv. tor at top.

\section{insmosiont}

sandstone and shale

\section{(av}

DUUERLY GROUP

mteme at base, pink shale in sendstone at top.

\section{Ts}

Hainowingiow blumgrey smile. abundan beds at top.

\section{ris}

athonimow

Ties, semstone and oolitio

\section{DI}

JiLT Fomtion

es and siltstanes with r lay at at bis.

\section{Tc}

Nithonation

Elititones, some thin beds of inim.

\section{IIPII \\ IIt TISSTONE}

et cremulat nod ifmestone.

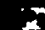

atlina shile

elestenes with local beds of

\section{5}

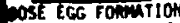

trone and beds of 7 imestone

\section{8}

CASPER FONIATTION

sandstone with linestone

\section{$y$}

Girtu Formation mbictene, siltstone and shale.

\section{IS}

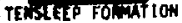

Tertly dolomitic ic sandstone. TOP crtys dolomistone.

\section{ros}

mestone sequence with Darw1 7 at base.

\section{Eln!}

IERT IARY

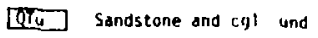

Ti Intrustives

volcantcs

North Dark fm

White hiver fm

Wha River im

Battle Spring $\mathrm{fm}$

Bridger $f m$

Washak ie fm

Dut ton Creek fm

Marrow Creek

mor

Cothedral blutfs tongue

fore union $f$ ir

Hanna fri

rerris $\mathrm{fm}$

fox Hylls im

ance for terb Medicine How in

Lewis sh

Mesaverae fol

CRETACEOUS

- Niobrera fm und

rontier im

Oakote ss

Claverly gp

\section{Junassic}

ratesstc

Lis

Jeim im

Chuguter $\mathrm{fm}$

PERMIAN

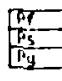

Forelle 1:

Gotasika sh

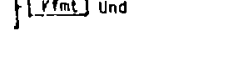

Thr]Green kiver im

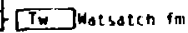

tThe und

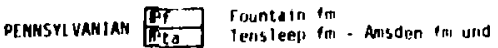

mississippian Datis Madison is

Cameariay

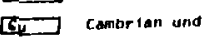

Jms [3] und

Tis nu und

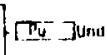

PRECAMGRIAN

[CT Mafic tqueous ror.

Schist

Granlte

Querts manzonite

Quartz diorlte

Guartzlee, blate and phyltite

Ganite ond awares monzenite

$\frac{u}{n}$
0
$\frac{a}{\alpha}$
$\frac{\alpha}{r}$
7 are.juns

[X] ] und

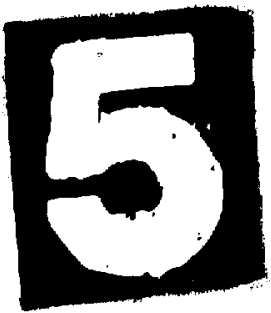

[iu] und

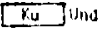

[kJum Und

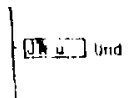

7

[PPD und

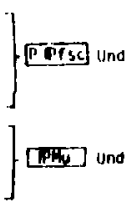

Tip

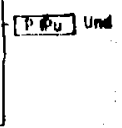

GEOLOGIC SYMBOLS

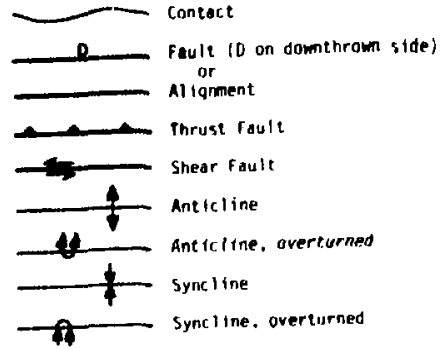




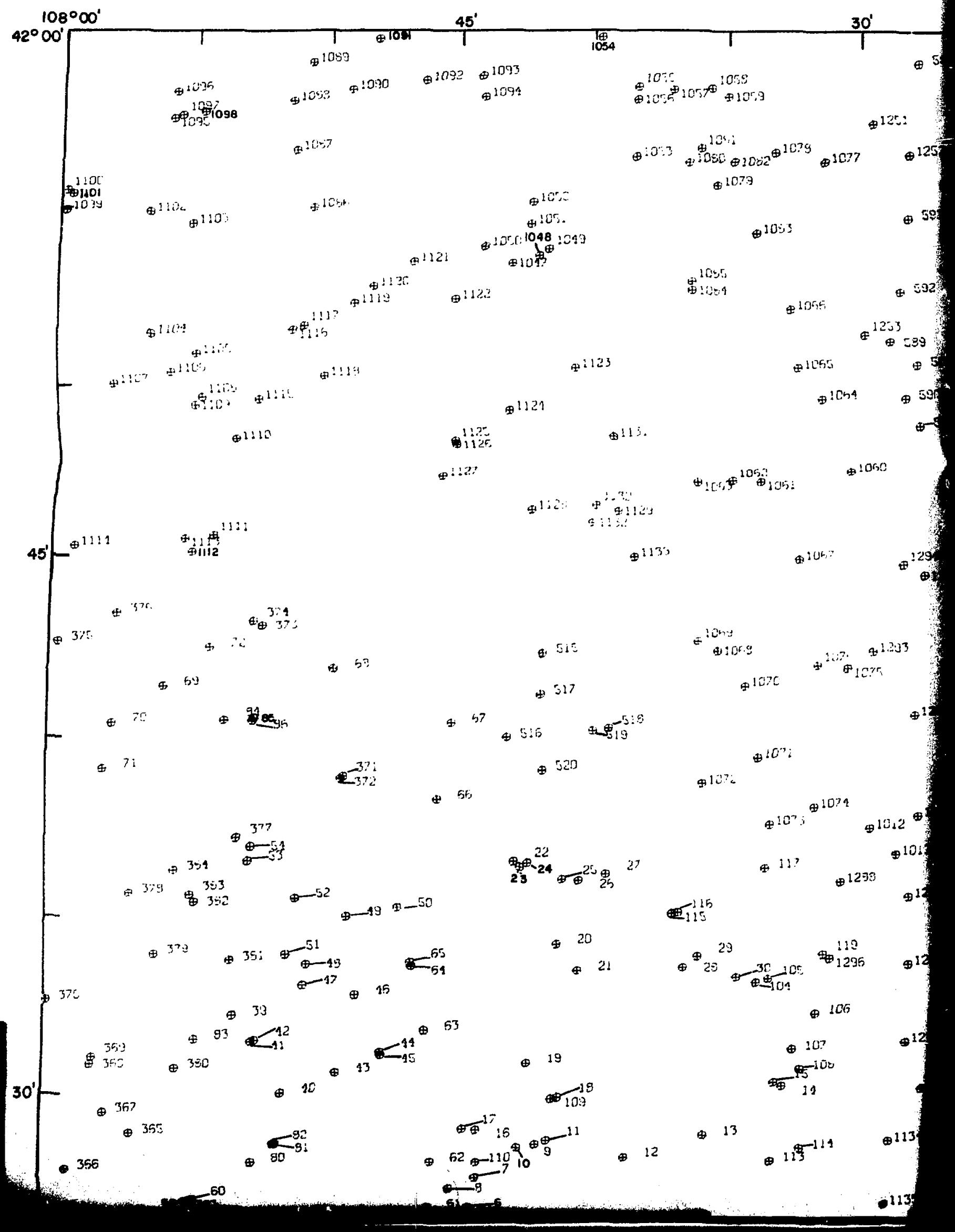




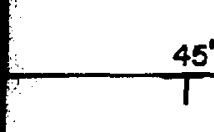

$45^{\prime}$

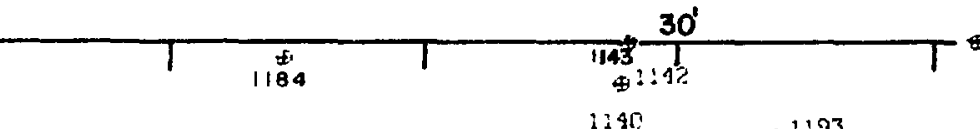

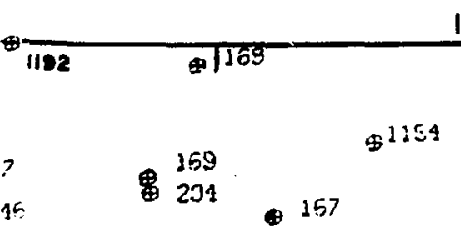

$15^{1}$

$\oplus^{1153} \oplus 513^{\oplus}$

$1279^{11 / 4}$

4:2: 9is

$\left.114\right|^{21994}$

की:3:

由1145

9

早 9152

95

$\oplus 5$

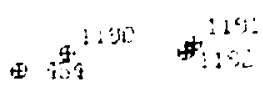

$91: 37$

Si: 13

stis 45

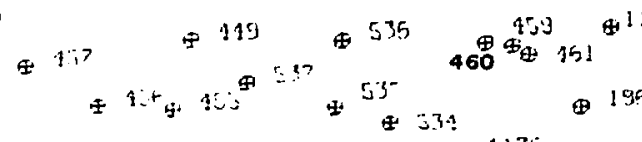

$$
\begin{aligned}
& \text { 4. } 121 \\
& \oplus^{4}: 3
\end{aligned}
$$

$\$ 115$

$\mp 20$.

$\$ 155$

$\oplus 50$

4:1145

$\oplus$ : UOS

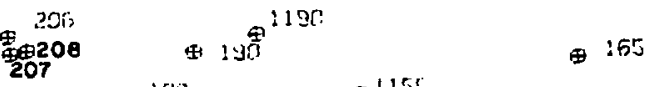

$$
\oplus ! 93
$$

$$
\text { (4) } 40
$$$$
\text { 4. } 193 \text { 由 } 11912212
$$$$
\text { *220 } 1: 56
$$$$
\begin{gathered}
193 \\
4: 63 \quad 191 \\
192
\end{gathered}
$$$$
+153
$$

4. $2 ! 961165$

6197

$4+161$

$0^{12.32}+\frac{1232}{1253}$

$$
\begin{aligned}
& \pm 3: \\
& 423 .
\end{aligned}
$$

Fin?

65

$$
\begin{aligned}
& g^{2}+2
\end{aligned}
$$

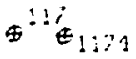

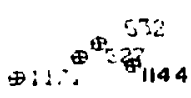$$
\text { क } 45 \frac{162}{4503}
$$$$
\oplus \overbrace{156}^{571} \oplus 15 \%
$$

क 575

$$
\text { 由:57 } 402
$$

255
139 435 由 190 $\oplus 1153$ 1153
$2: 2$ 211 盟 $\operatorname{An}^{13:}$ 由1167 由1157 


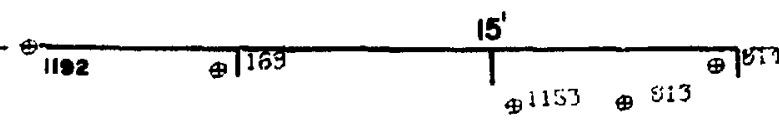

$\oplus^{1193}$

$$
\begin{aligned}
& \theta^{1117} \\
& 0^{1145}
\end{aligned}
$$

\$11:5

电 209

๓157

$\Phi^{1151}$

${ }^{4} 20 \%$

$\$ 155$

4: 1119

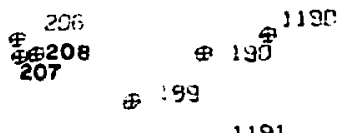
$\oplus^{1191}$

451 \& 193

由 195

$$
\begin{aligned}
& 4^{153} 1: 59 \quad 191 \\
& +107
\end{aligned}
$$$$
\text { Q }
$$

$$
\oplus \text { 䵫1222 }
$$$$
\text { 由 } 220
$$$$
\text { Q1:65 }
$$

由 165

㽞 $32:$

๑5 210 क 312 由15

\section{PLATE III}

- 15920 $\left.170^{4}\right]^{420} 00^{\prime}$

9921

$\oplus 905$
$99: \%$

$4^{953}$ 9:3

(17)
由 $\begin{aligned} & 17 j \\ & 6172\end{aligned}$

$\oplus 174$

$\$ 9: 9$ 


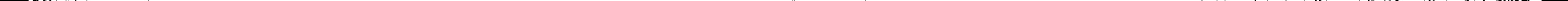




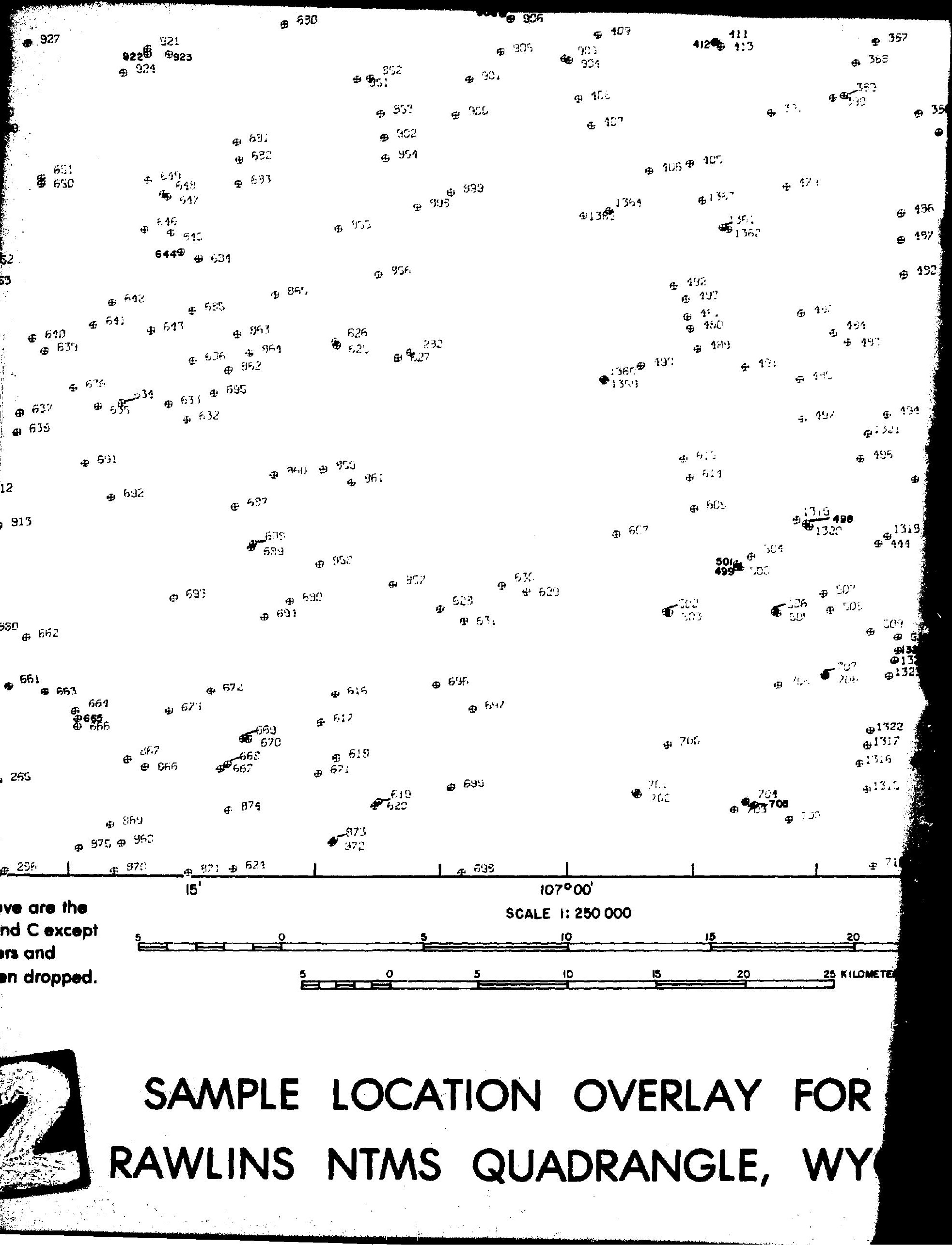




$$
e^{1355} \Psi^{732}
$$

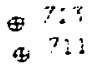

$\pm 233$

$\Phi 245$$$
\begin{aligned}
& 245 \\
& 243
\end{aligned}
$$$$
325
$$$$
\mp 25
$$

- 355

$\oplus 115$

43

由 923

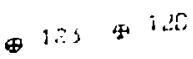

$\oplus$

*3:"

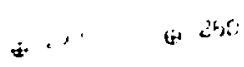

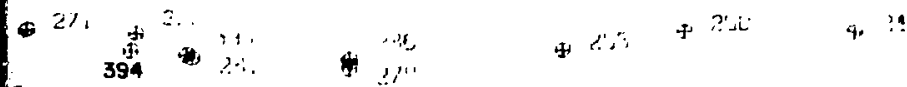

$$
\begin{aligned}
& \pm \because \because \\
& 4 \% \\
& 4 \ddot{i}
\end{aligned}
$$

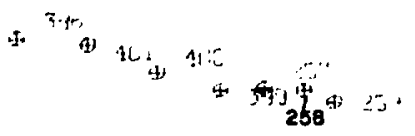

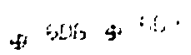

$$
\begin{aligned}
& \text { +. : }:-
\end{aligned}
$$

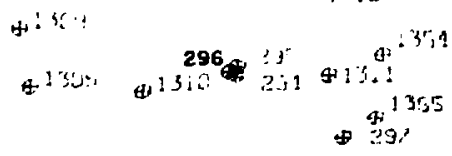

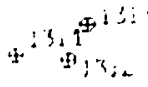$$
+27 \pi
$$$$
93: 2+31 ?
$$$$
330 \% \frac{34}{7}
$$

象 $\begin{aligned} & 913 \\ & 329\end{aligned}$

*.7 735

由3.

由?

a 13

g. $34 \mathrm{~s}^{3}$

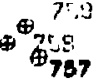

$$
\begin{aligned}
& \text { c } 123
\end{aligned}
$$

4. 12?

9 77

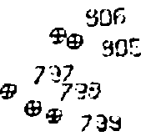

\section{\& IN:}

$6 ! 35+19 !$

$$
\begin{aligned}
& \text { 9.12 由.2t } \\
& \text { ต } \\
& 4143 \quad 5 \begin{array}{l}
121 \\
125
\end{array}
\end{aligned}
$$

$$
\begin{aligned}
& \text { 6. } 11 \\
& \text { a } 3: 2
\end{aligned}
$$

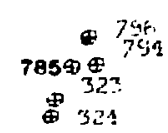

$$
\begin{aligned}
& 9 \begin{array}{r}
763753 \\
4
\end{array}
\end{aligned}
$$

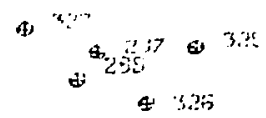

4.

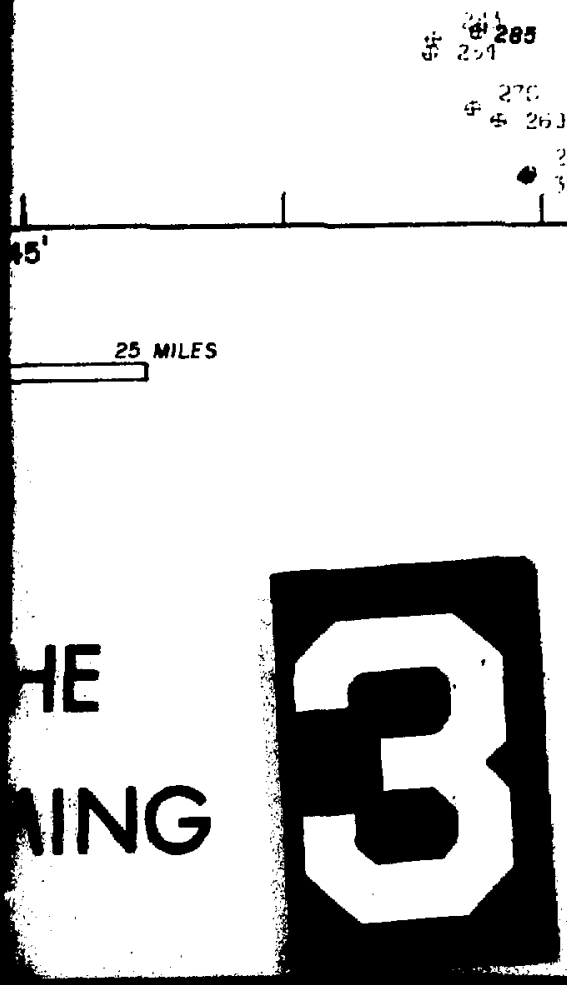

4.

4 $2 \mathrm{di}$

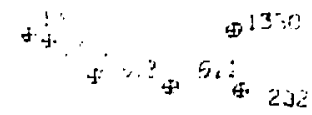

* 29?

9) 7,55 


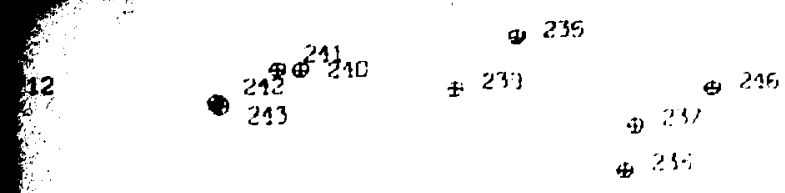

$5 \% 5$
$0 ? 7$

0332

5. 325

4. $10:$

(19) 1004

$1003 \%$

1002

1006 界1007

4. 27

$3309, \because$

$3 i 0$

$43:$

$4 \%$

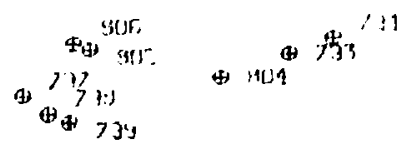

9. 7.52

o. $y, 1$

a $4 \%$ प1\%

(4)

(1) $7 \times$

म $\because 1$

(- $i^{2}$

in

(3) $7: 37$

251

$914:$

$$
\text { (4) }
$$

(5. 7 : :

12:

$$
\text { (4) } 1.2: 1
$$

w

$$
\text { +. } 132 \text { का }
$$

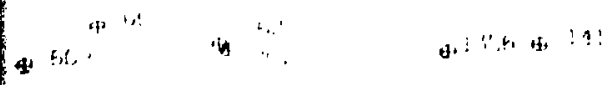

$$
\text { 9: : } 4:
$$

(4)

$$
\text { in in }
$$

417

a. 1.2

4. 7

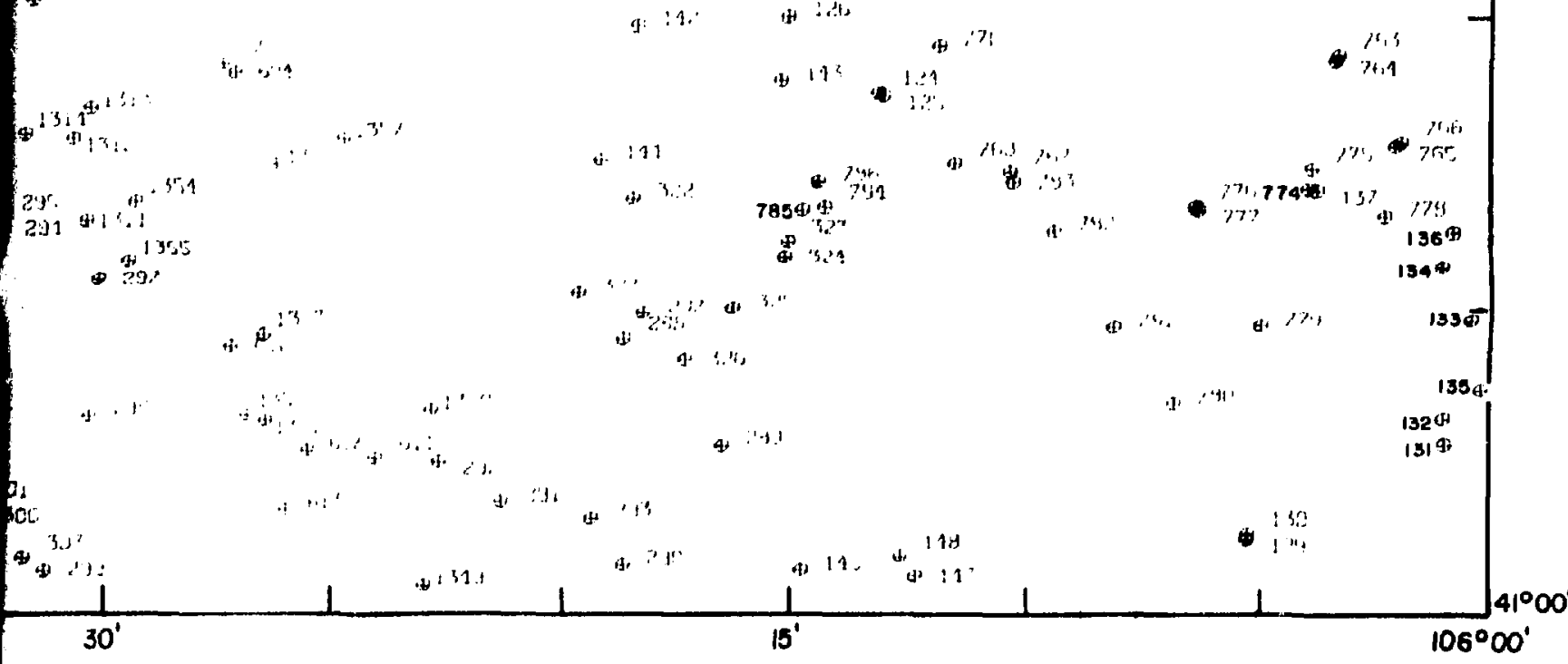

N
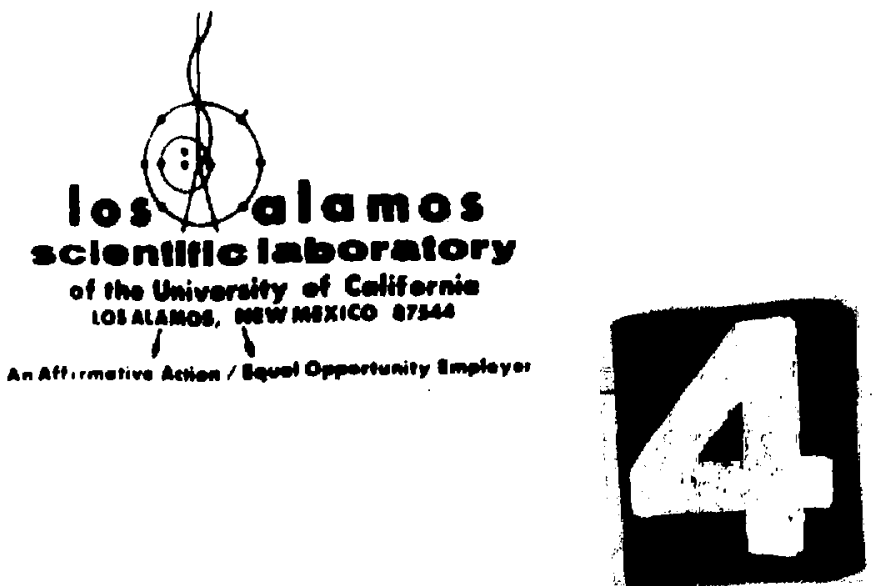


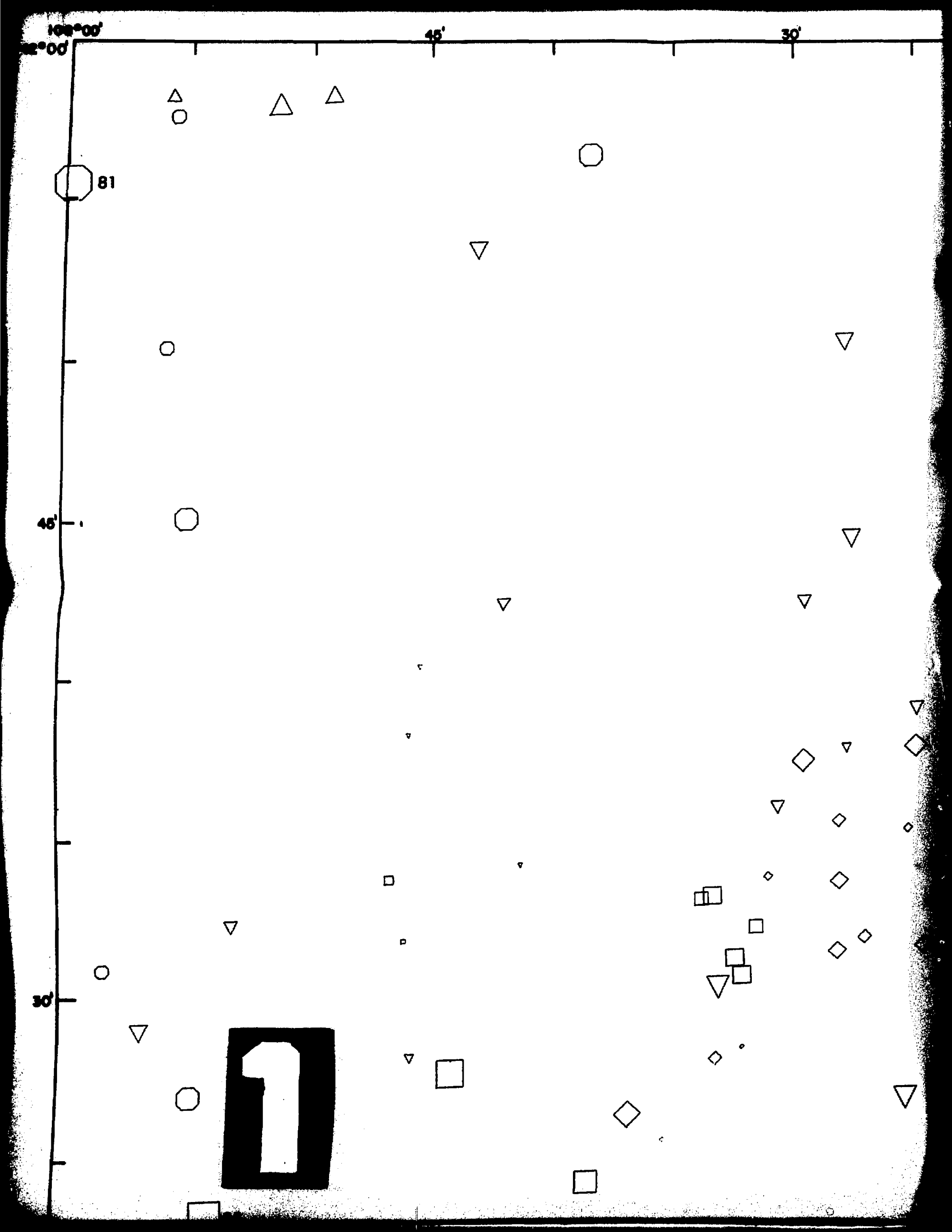




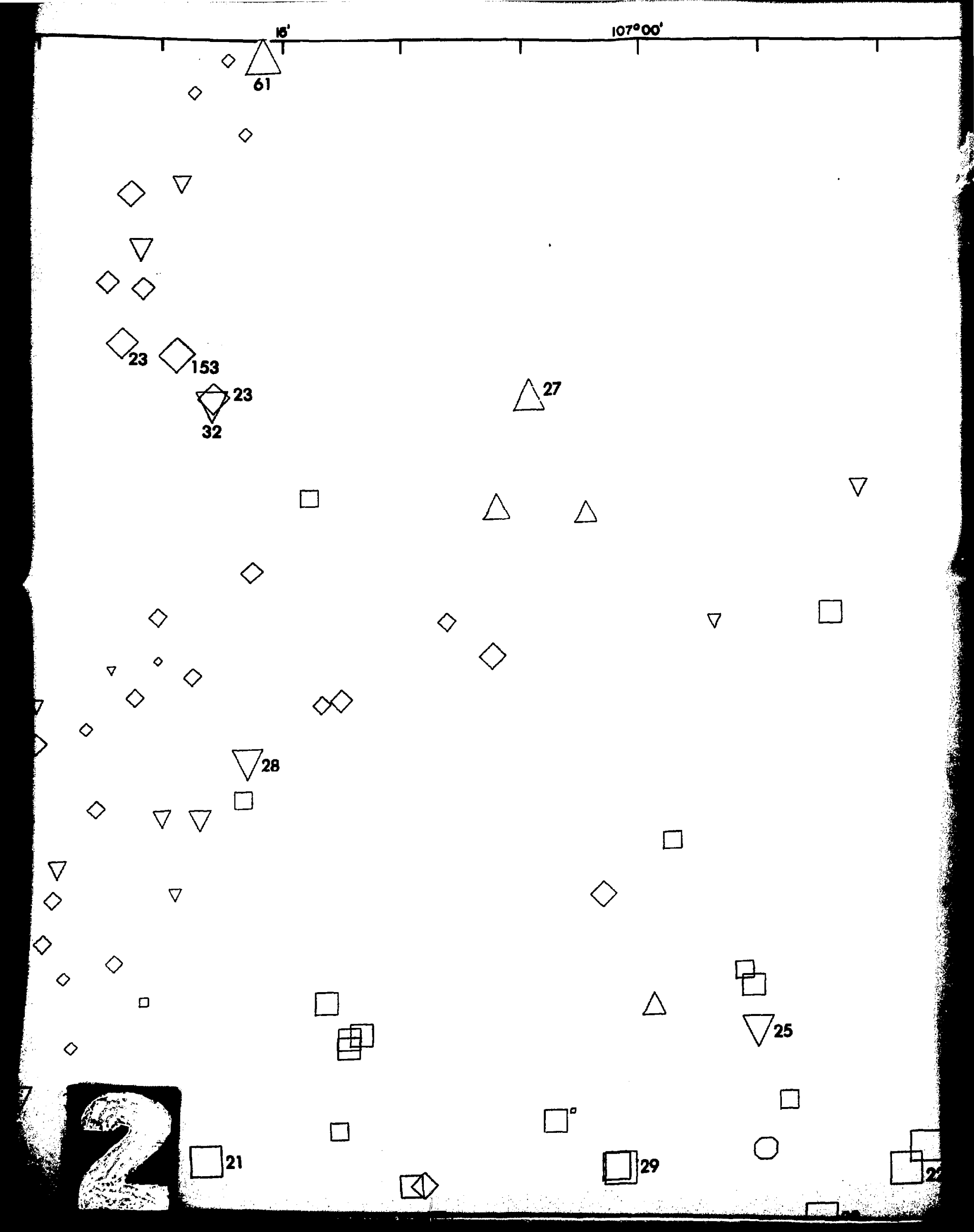




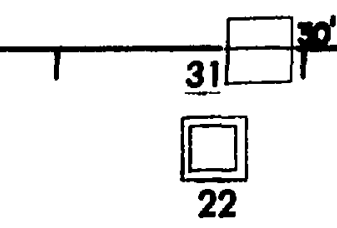

1
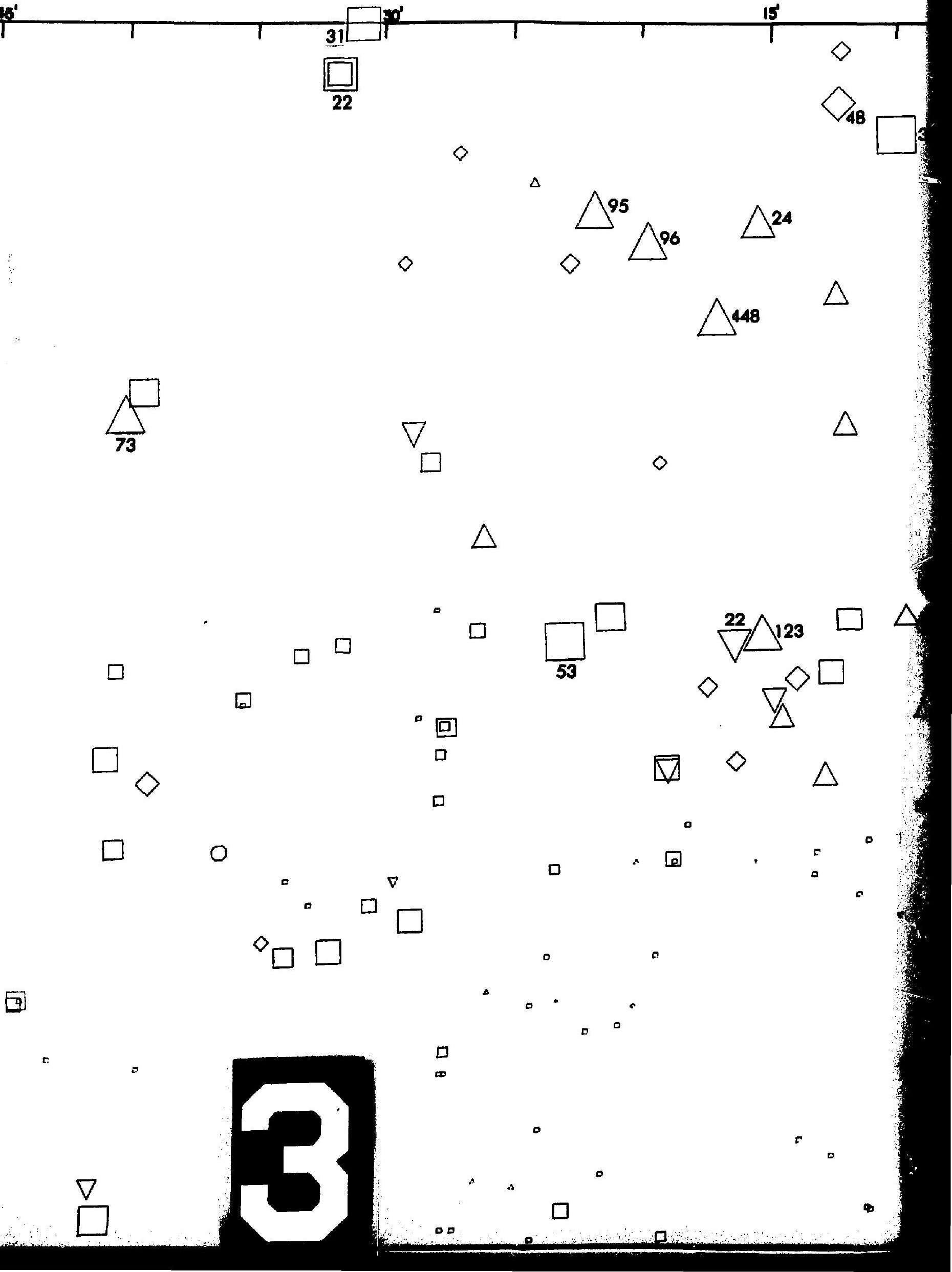


\section{PLATE III}

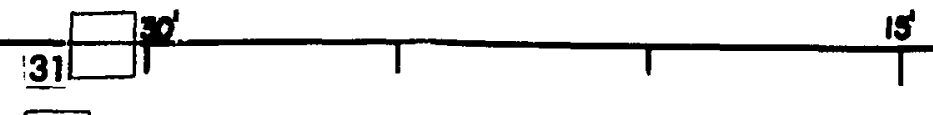

$\square$

$\diamond$

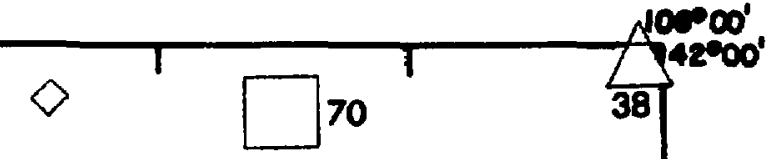

0

$\Delta$

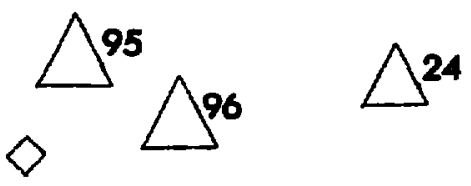

$\triangle 48$

$\triangle$

$\widehat{V}_{48} \square_{35}$

$\nabla$
$\square$

$\triangle$

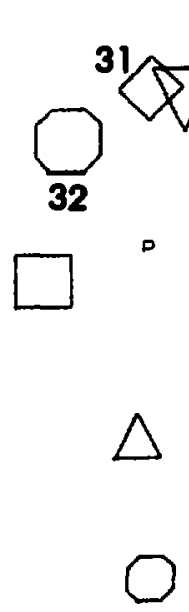

$\diamond$

0

$\square \square$<smiles>C1CC1</smiles>

口回<smiles>C1CC2CCC12</smiles>

$-\square$

口

$\square$

$\nabla \diamond$

$\triangle$

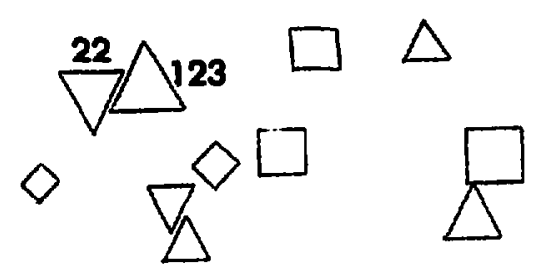

$=\quad \square^{\nabla} \square$

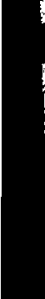

$\square$

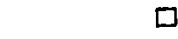

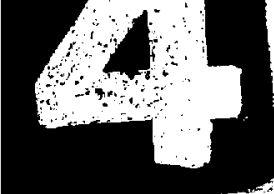

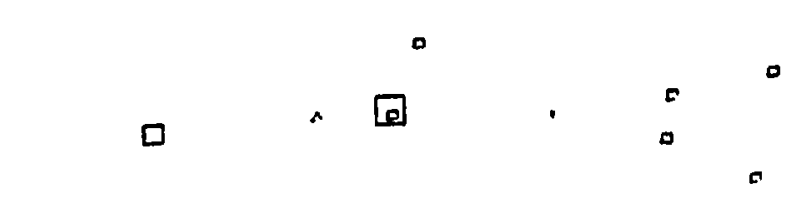

$\triangle$ 


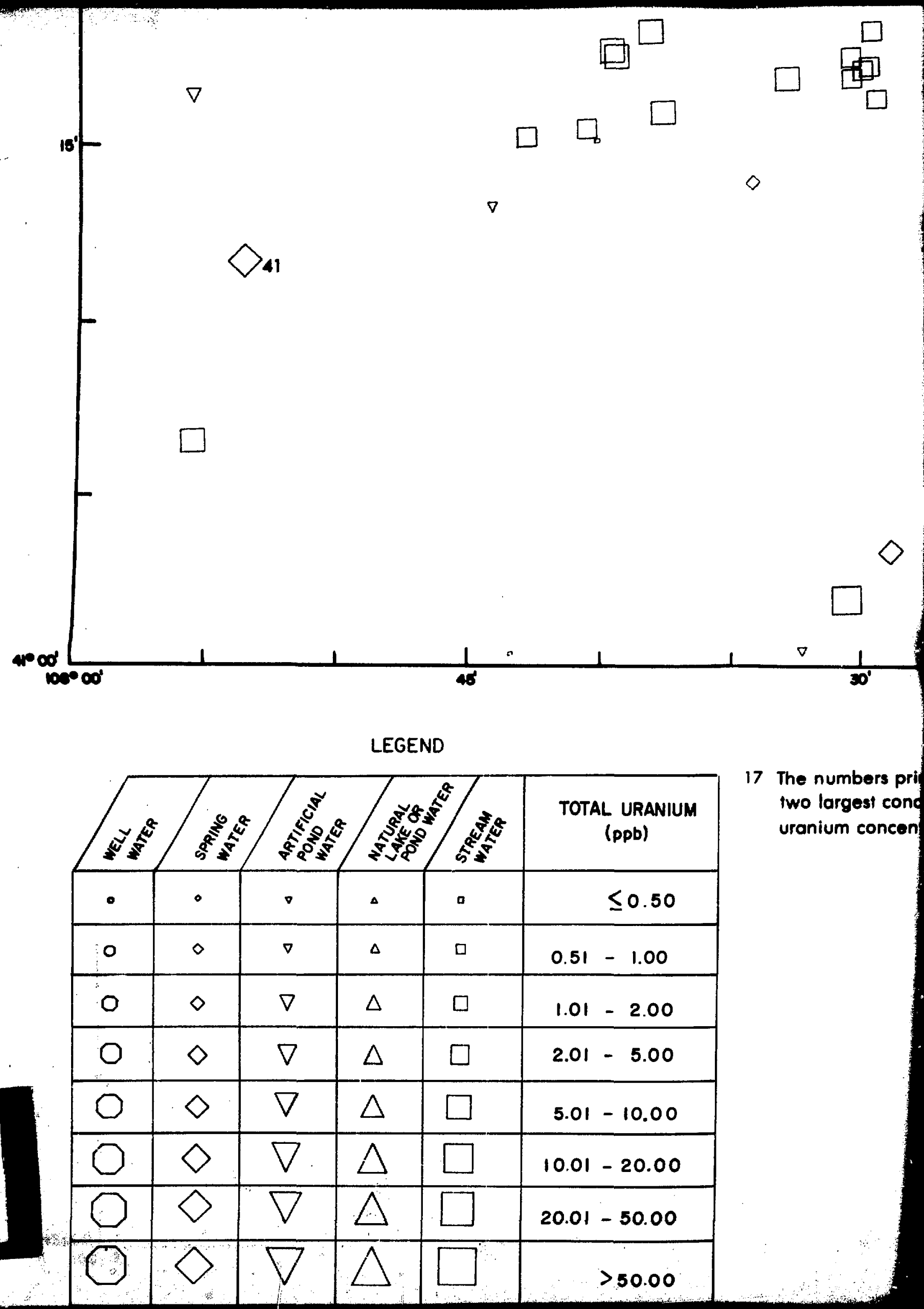




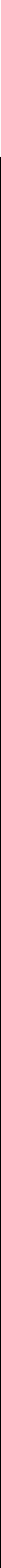




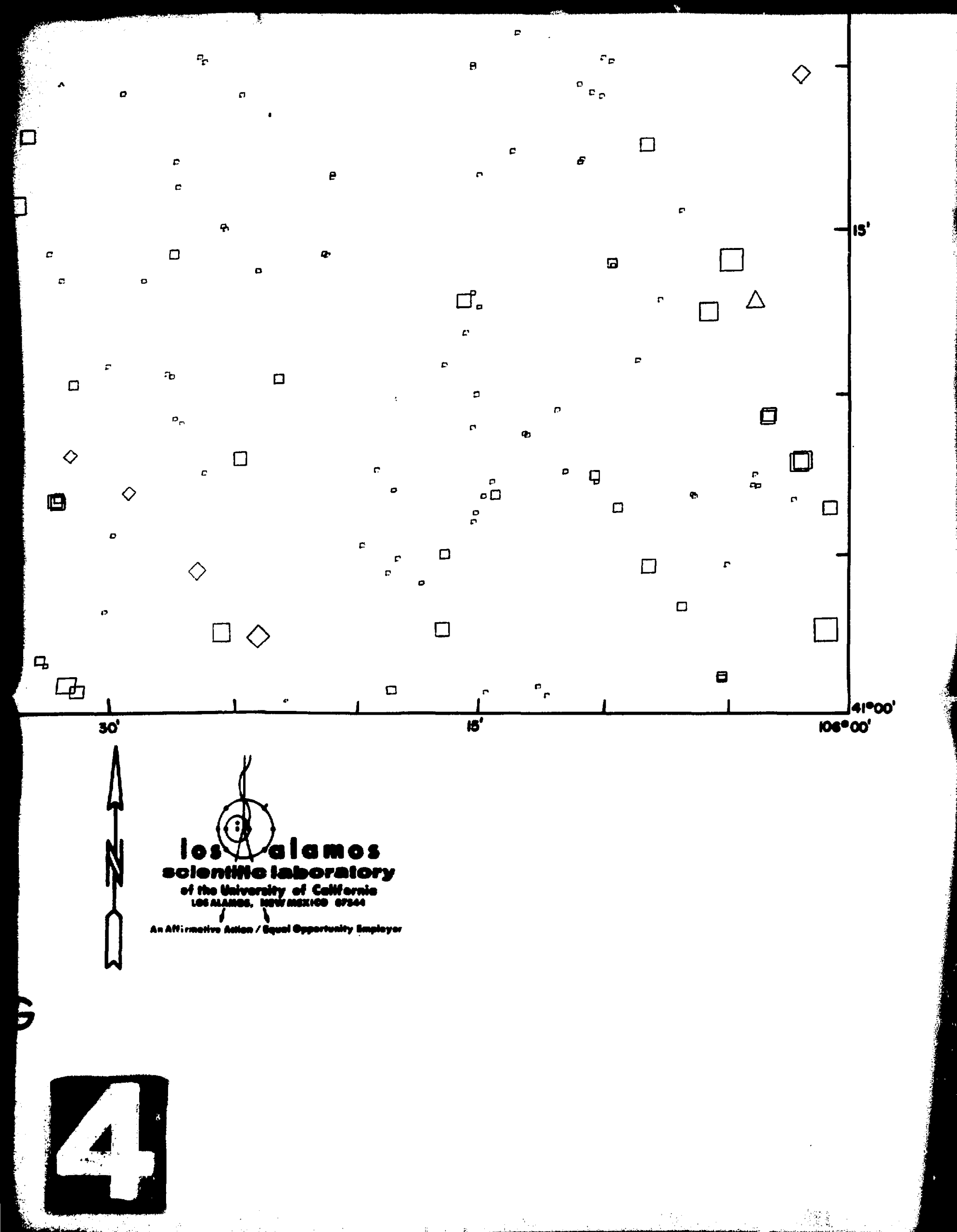




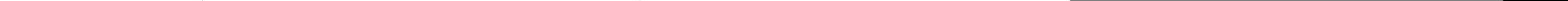




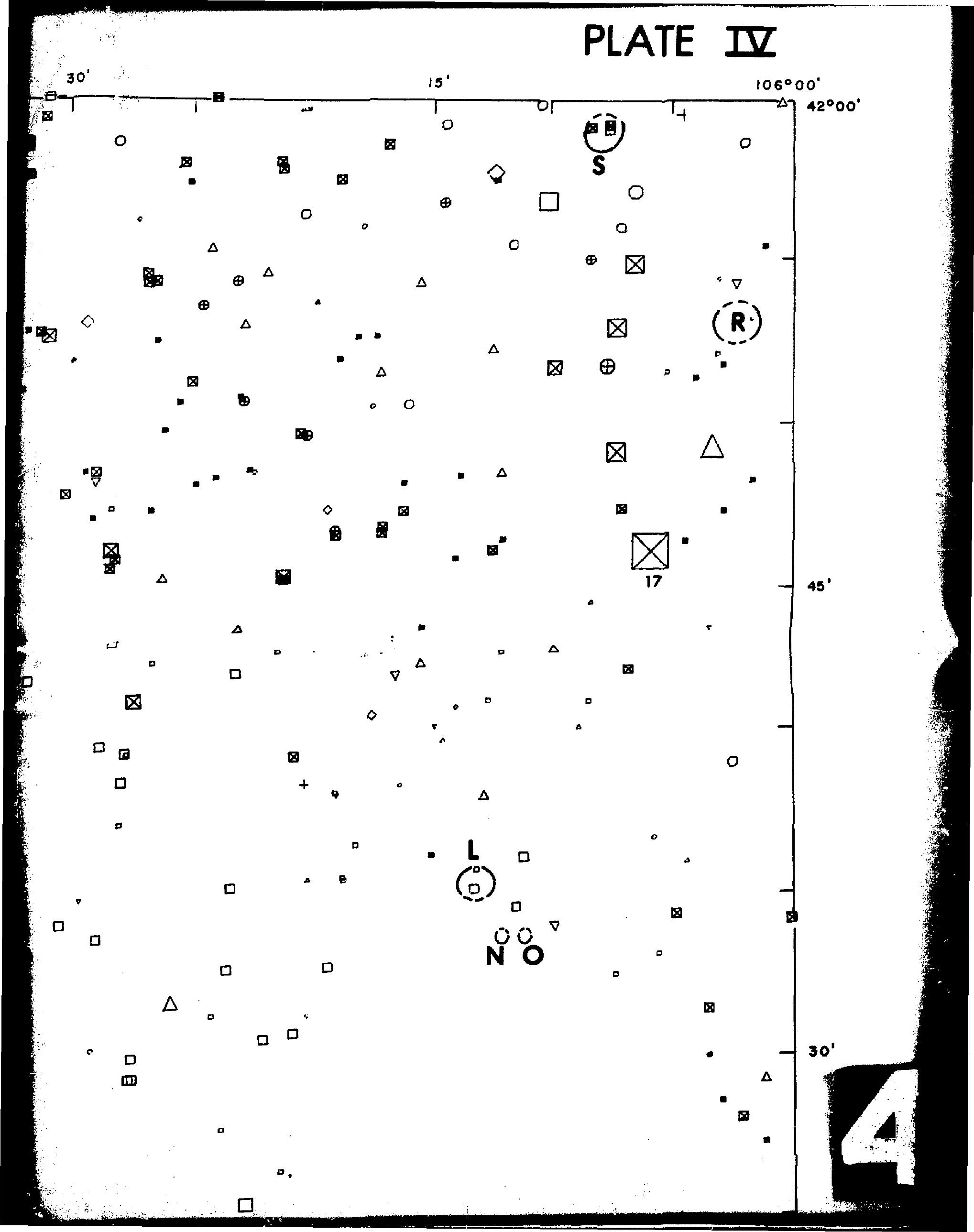




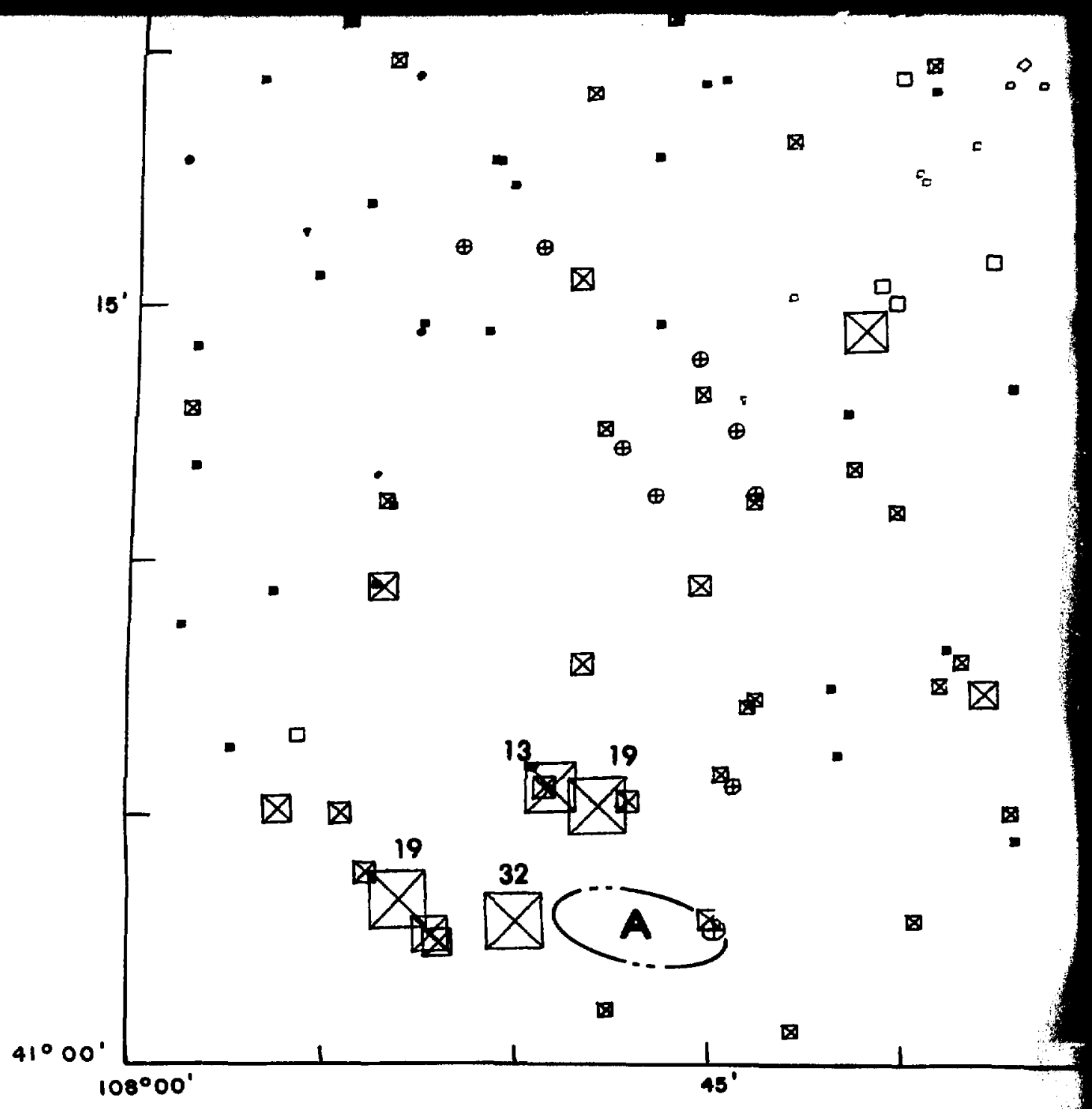

\section{LEGEND}

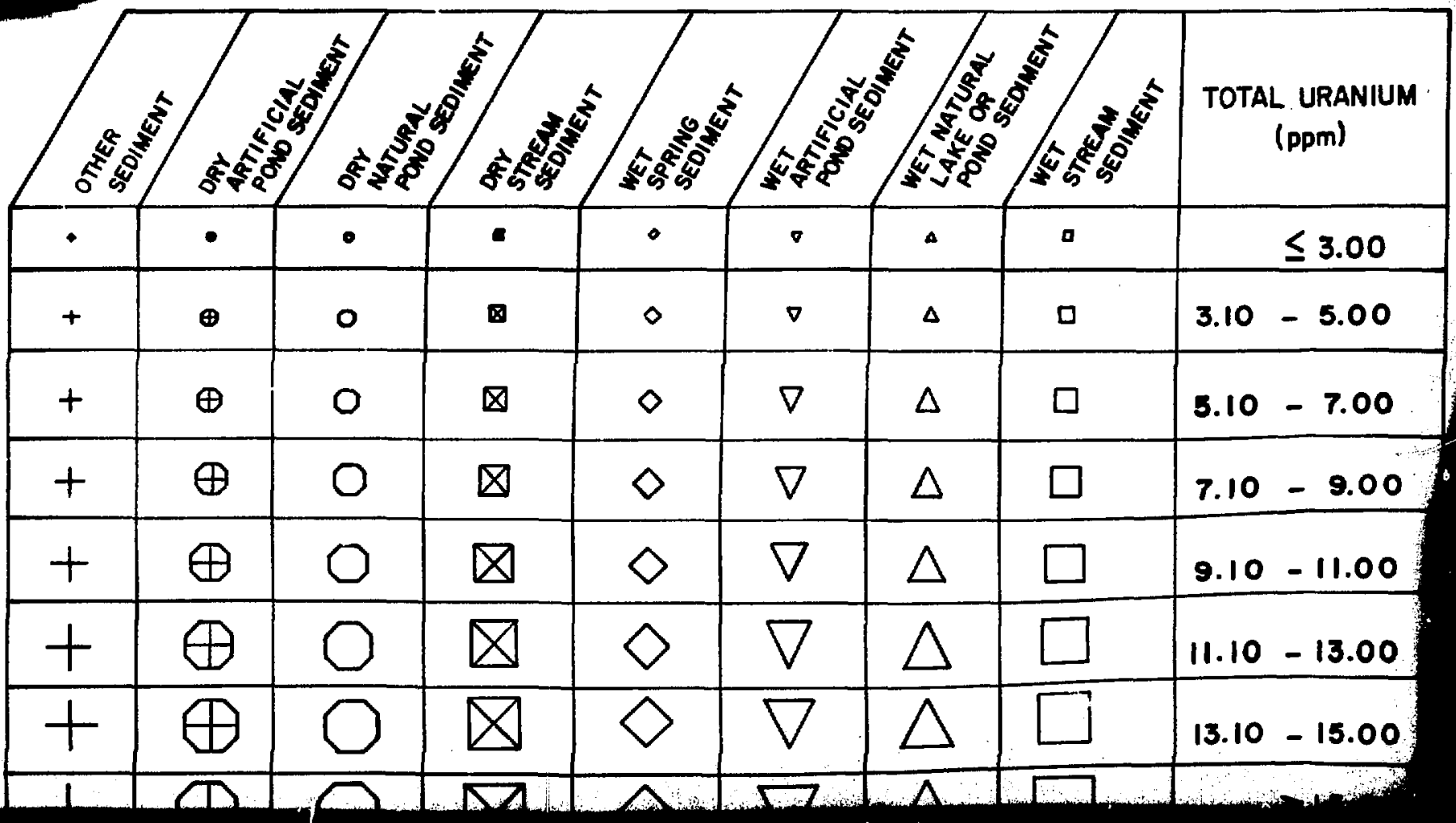




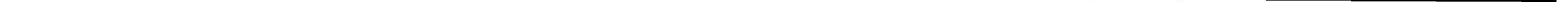




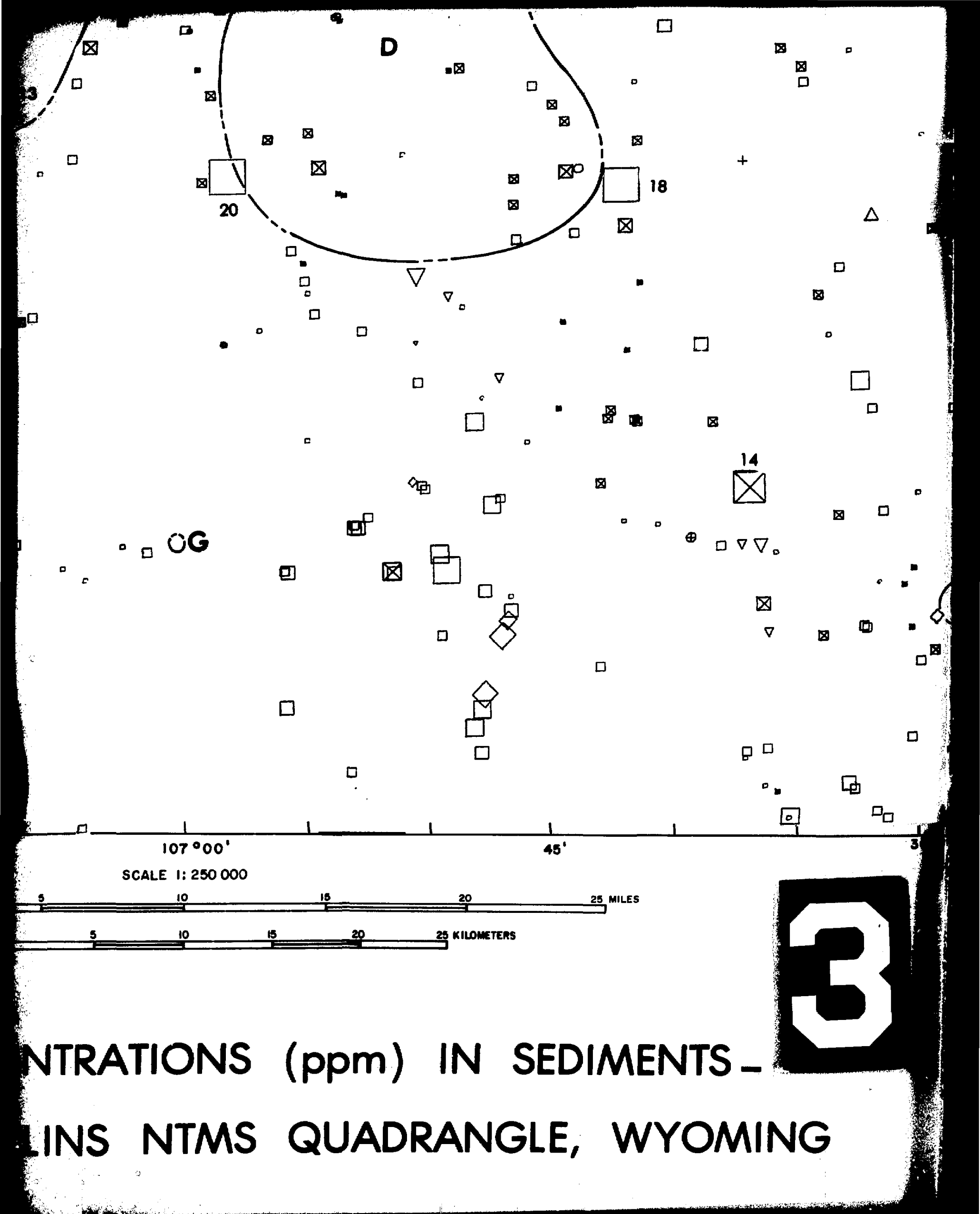


